\title{
LIVING TOGETHER IN A RELIGIOUS PLURAL SOCIETY: INDONESIAN TEACHERS' AND STUDENTS' PERCEPTIONS ON CITIZENSHIP, IDENTITY \& RELIGIOUS TOLERANCE
}

\author{
BEN K. C. LAKSANA \\ A thesis submitted to the \\ Victoria University of Wellington \\ in fulfilment of the requirements for the degree of \\ Master of Education \\ Victoria University of Wellington \\ 2014
}





\section{Acknowledgements}

There are a number of people without whom this thesis might not have been written and to whom I am greatly indebted.

First and foremost I would like to thank my supervisor, Bronwyn Wood, for her constant, never ceasing support and encouragement. Having her as my mentor this past year has pushed me to develop not only my meagre writing skills but also expand my knowledge on matters I have never thought of or even heard of. I am extremely grateful of having such a caring and knowledgeable supervisor such as her.

My research would not have taken place were it not for the teachers and students of the three case study schools. Thank you for your time to take part in the interviews.

To my mom, my brother and sister, I thank you for all the long-distance support that you have given me throughout my stay here in New Zealand. My work here is done, on to the next.

Many thanks to my friends here in Wellington: Rose, Ross, Rosie, Rosa, Hadleigh, Louise, Elli, Elle, Jon, John, Caitlyn, Dylan, Emir, Keni, Ardya, Henry, Bryan, Ren, Aaron, Tapuwa, Art and Mba Dwi. Thank you for all the childish laughs, the beautiful food, the late night talks and the shoulders to cry on. It's been a fun ride but it's time to go home.

I would like to thank the NZ Aid Scholarship for giving me the chance to study here in New Zealand. I hope I come home not only as a better scholar but a better person as well.

To Rara, thank you. For her unwavering love, her endless patience, the hours-long Skype chat as I toil through the night, lamenting on my quarter-life crisis and my broodings on life. Thank you will never be enough.

And last I would like to thank my dad, wherever you are, thank you for the initial support and the hard earned wisdom that you have given to me even if you are no longer here. 


\begin{abstract}
This study investigates Indonesian secondary school teachers' and students' perceptions of citizenship, religion and religious tolerance. It explores how participants negotiate their citizenship and religious identities, and looks at how religious tolerance is understood and defined.

The study involves religious education and citizenship teachers $(n=8)$ and students $(n=20)$ from three different schools in Jakarta, Indonesia. The schools were purposely selected to represent a range of philosophical approaches to religion and included a Madrasah, a private school and a public school. This study discovered that both teachers and students intertwined their religious and citizenship identities to produce a form of 'religious citizenship'. The study also found that both teachers and students generally saw religious tolerance as a necessity to manage inter-religious relations. Many of the strategies teachers employed, which were also supported by curriculum documents, overlooked the complexity of inter-religious identities and in particular, the equality of minority religious groups. Most teachers perceived religious tolerance through an exclusivist view whereby religious tolerance was limited to social tolerance, while many student participants provided more progressive and inclusive definitions of religious tolerance that often reflected their lived experiences of engaging in inter-religious relations.

In conclusion, the study argues that both teachers and students constantly negotiate their citizenship and religious identities in order to find ways to live together in a religiously plural society such as Indonesia. While students and teachers in this study agreed that finding ways to promote and sustain inter-religious harmony in Indonesia was a high priority, many challenges relating to the teaching and practice of religious tolerance in Indonesia still remain.
\end{abstract}




\section{Table of contents}

Acknowledgements ................................................................................................................................. i

Abstract................................................................................................................................ ii

Table of contents.............................................................................................................. iii

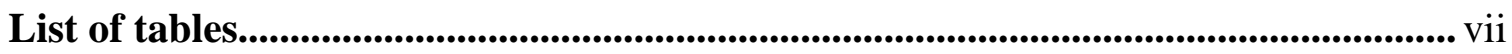

Glossary and abbreviations....................................................................................................... viii

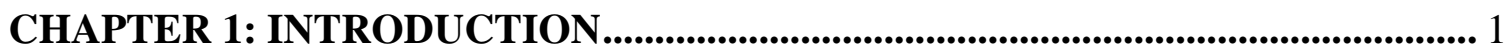

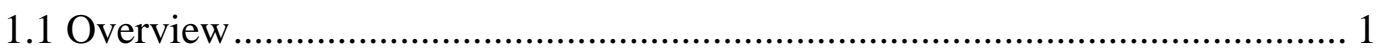

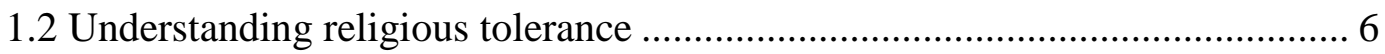

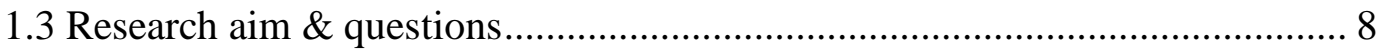

1.4 Personal incentive for research ................................................................ 9

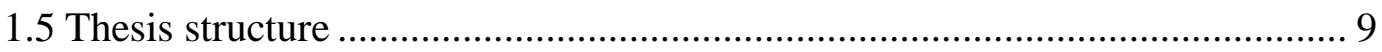

CHAPTER 2: CONTEXTUAL BACKGROUND OF RESEARCH..............................11

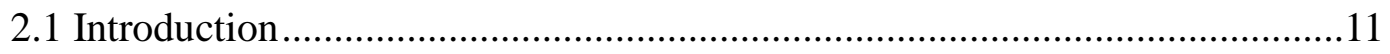

2.2 Freedom of religion in Indonesia ................................................................11

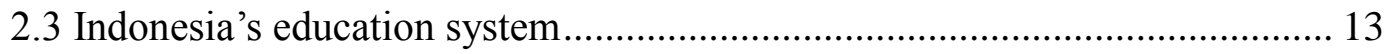

2.3.1 Contextual background of Indonesia's national curriculum ............ 14

2.3.2 Contextual background of Islamic schools ...................................... 18

2.3.3 Contextual background of citizenship education and religious in the national curriculum ............................................................................ 20

2.4 The current Indonesian National Curriculum: Religious and Citizenship

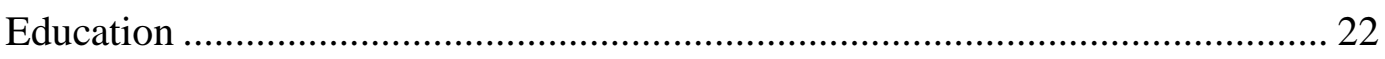

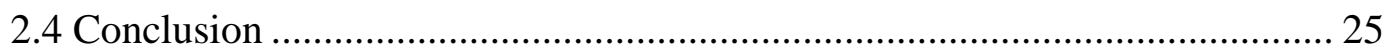

CHAPTER 3: LITERATURE REVIEW AND THEORETICAL FRAMEWORK . 26

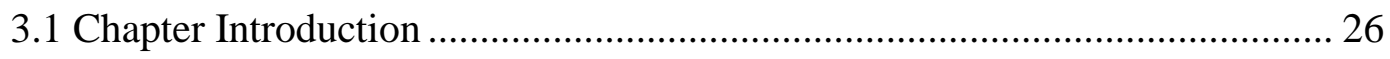

3.3 Descriptions of citizenship and identity ....................................................... 27 
3.3.1 Religious citizenship..................................................... 31

3.4 Conceptual framework for religious education....................................... 33

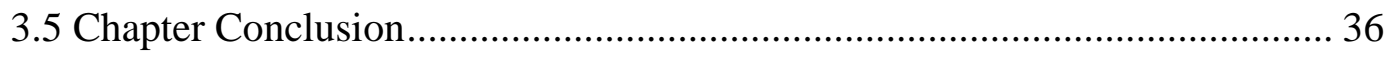

CHAPTER 4: METHODOLGY .............................................................................. 37

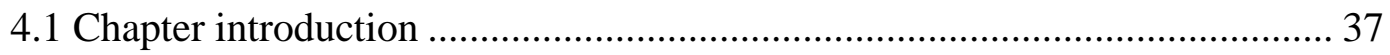

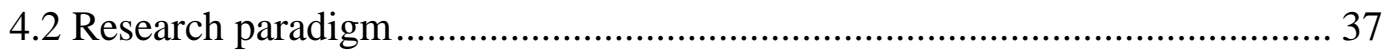

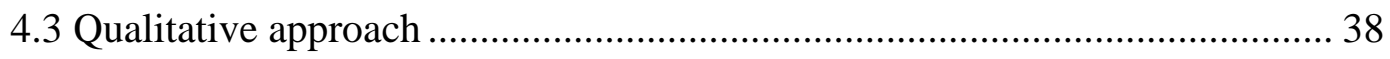

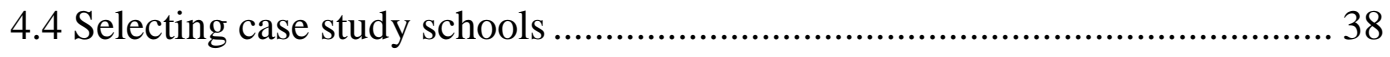

4.4.1 Description of case study schools .............................................. 39

4.4.1.1 Jakarta Madrasah High .............................................. 40

4.4.1.2 Jakarta Public High .................................................... 42

4.4.1.3 Jakarta National High ............................................. 42

4.4.2 Description of participants from each school ............................. 45

4.5 Data collection methods................................................................. 47

4.5.1 Semi-structured Interviews ................................................ 47

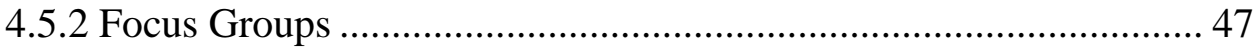

4.5.3 Secret Box Activity ........................................................ 49

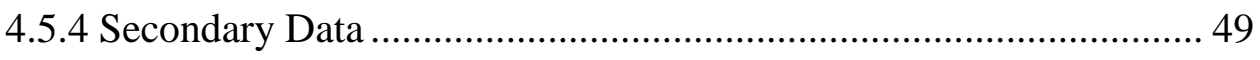

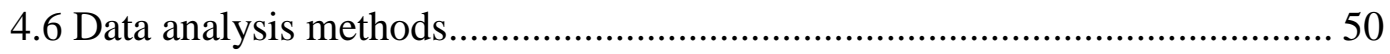

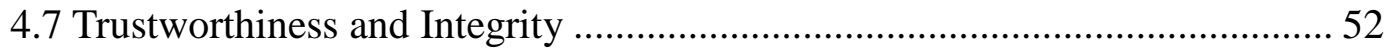

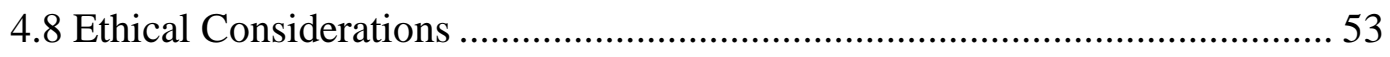

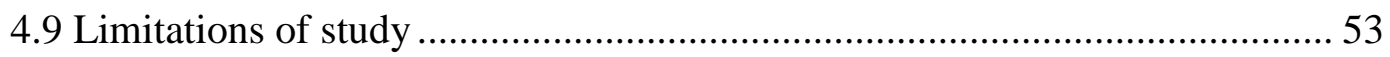

CHAPTER 5: SECONDARY SCHOOL TEACHERS' AND STUDENTS PERCEPTIONS TOWARDS CITIZENSHIP, RELIGION AND IDENTITY ......... 55

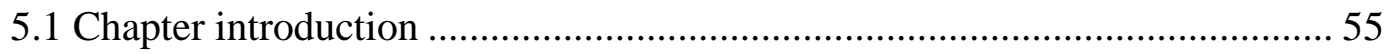




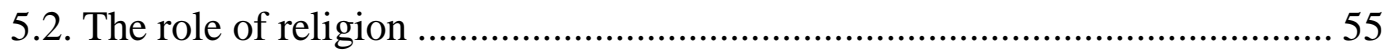

5.2.1 Schools and religion..................................................................... 56

5.2.2 Religion and the construction of the moral self ................................ 58

5.2.3 Views of religious education in schools............................................ 63

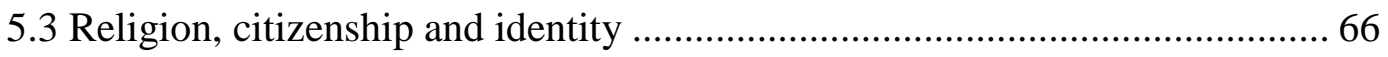

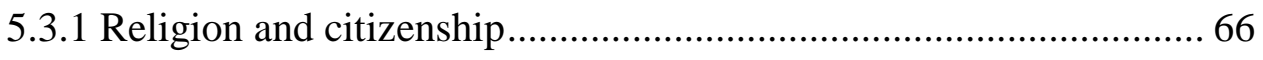

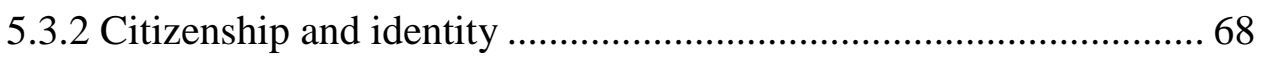

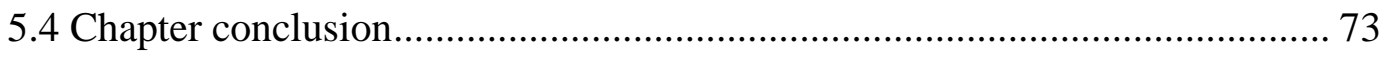

\section{CHAPTER 6: SECONDARY SCHOOL TEACHERS' AND STUDENTS'} PERCEPTIONS TOWARDS RELIGIOUS TOLERANCE .......................................... 75

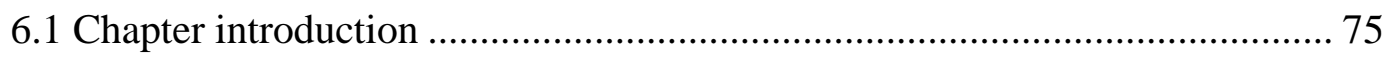

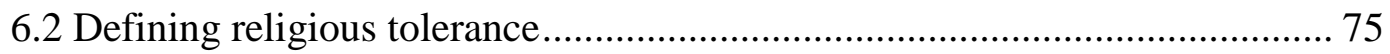

6.3 Perceptions and practices of teachers and students regarding religious

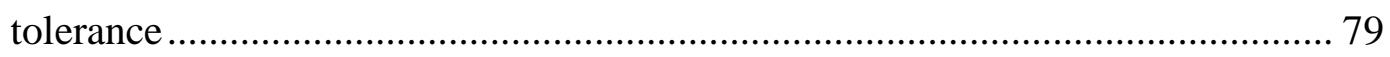

6.3.1 Tolerance as a necessity for managing diversity and national unity 79

6.3.2 Concerns about religious tolerance ……………………………....... 84

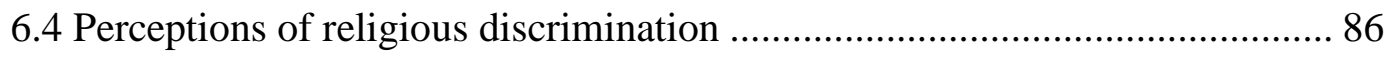

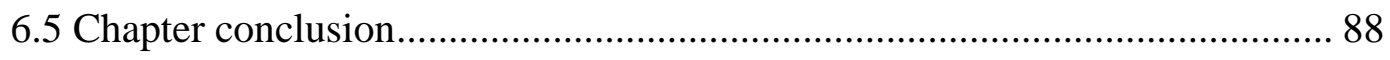

CHAPTER 7: DISCUSSION ................................................................................................... 89

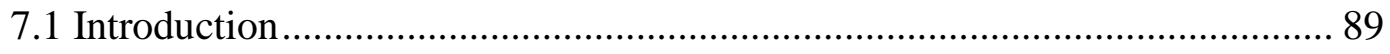

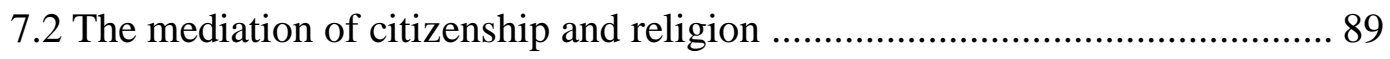

7.3. Issues of Indonesia's inter-religious education ............................................... 96

7.4 Chapter summary ...................................................................................... 101

CHAPTER 8: CONCLUSION............................................................................................ 103

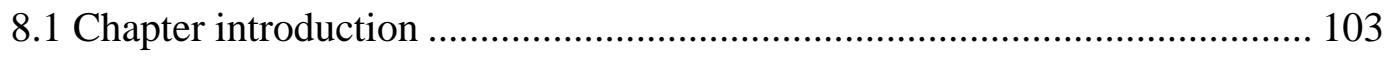




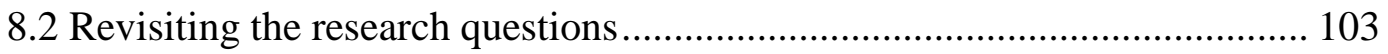

8.3 Implication for stakeholders ........................................................... 105

8.4 Limitations of study and further research .............................................. 106

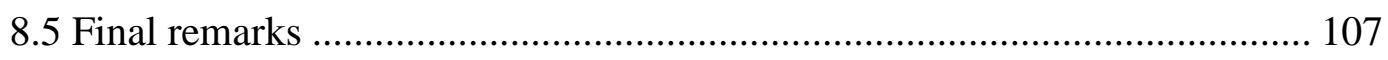

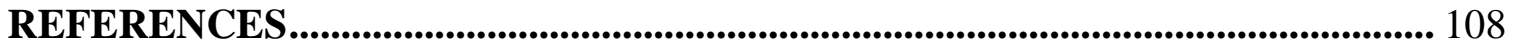

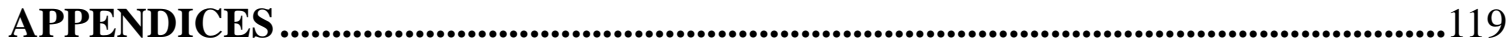

Appendix A: Information sheet for schools ................................................119

Appendix B: Consent to participation in research for schools ........................ 121

Appendix C: Information sheet for teachers ............................................. 122

Appendix D: Consent to participation in research for teachers ....................... 124

Appendix E: Information sheet for students ......................................... 125

Appendix F: Consent to participation in research for students ....................... 127

Appendix G: Demographic information ................................................... 128

Appendix H: Questions for focus group and semi-structured interviews.......... 129 


\section{List of tables}

Table 4.1: Profile comparison of case study schools...............................40

Table 4.2: Summary of participants from each school..............................45 


\section{Glossary and abbreviations}

Ahmadiyya

: An Islamic religious movement founded by Mirza Ghulam Ahmad in British India near the end of the 19th century. He claimed to have fulfilled the prophecies of the world's reformer during the end times.

Al Qur'an/Qur'an : The main religious text of Islam.

Fatwa : Religious edict usually created by the Indonesian Ulema Council (MUI).

Hadith : The sayings of the Prophet Muhammad.

Hijab : Islamic headdress.

JIL : Jaringan Islam Liberal (Islamic Liberal Network)

KTP : Kartu Tanda Pengenal (national identity card)

Madrasah : Islamic day school.

MUI : Majelis Ulama Indonesia (Indonesian Ulema Council).

Pancasila : The philosophical foundation of Indonesia. It comprises of five interrelated principles: (1) the belief in God, (2) a just and civilized humanity, (3) the unity of Indonesia, (4) democracy guided by deliberations arising from representatives, (5) social justice for all of the people of Indonesia.

Pesantren : Islamic Boarding School

PMP : Pendidikan Moral Pancasila (Pancasila Moral Education)

SARA : Ethnicity (Suku), religion (Agama), race (Ras) and interclass (Antar golongan).

Sharia : Islamic religious law

Shi'ah/Shi'a/Shiite : The second largest denomination of Islam, believing Ali, the prophet Muhammad's cousin, as the true successor after prophet.

Sunni

: The largest denomination of Islam, believing Abu Bakr, the companion of the prophet Muhammad as the true successor of the prophet. 




\section{CHAPTER 1: INTRODUCTION}

\subsection{Overview}

The goal of constructing a national identity in a deeply diverse society such as Indonesia is not without its challenges. Essentially with this cultural, ethnic, religious diversity comes a diverse range of values. Issues such as which values should go into the construction and maintenance of national identity are often hotly debated, as individuals have their own personal perceptions of what is valuable in life, which may include their personal tastes or their religious beliefs (Miller, 2000).

Despite the diversity of religion and ethnicity in Indonesia unity remains a core value. The concept of unity can be seen in Indonesia's education system as it reinforces the construction of an imagined community, and also in Indonesia's national motto "Bhinneka Tunggal Ika" or "Unity in Diversity". However, following the fall of Suharto's authoritarian regime in 1998, there has been substantial evidence of religious intolerance and radicalism in Indonesia becoming more visible. This display of intolerance may be the result of democratization as the change from an oppressive authoritarian regime into an open democracy has allowed citizens to express more freely of their beliefs. But nonetheless, as this intolerance has been increasingly noticeable within Indonesia it has resulted in social tensions. With this, itt must also be noted that there has been a rise in Indonesia's religiosity. For instance, Indonesia was once deemed home to the worlds' largest group of secular Muslims, yet studies have shown that Indonesia today has one of the highest levels of Muslim adherents (Hefner, 2013; Pohl, 2011).

The 2013 U.S. Commission on International Religious Freedom Annual Report, stated that Indonesia has shown "its stability and its robust democracy with political institutions protecting human rights" (p.236); however, in the past decade there have been on-going sectarian tensions, societal violence, and the persecution of religiously unorthodox sects. This has threatened the country's long traditions of religious tolerance 
and pluralism.

There has been evidence in recent years that suggests an increase in sectarian tensions among religious groups in Indonesia. Reports by organizations such as the Human Rights Watch (HRW, 2013), the US Commission on International Religious Freedom (USCIRF, 2013) and local non-governmental organizations such as the Wahid Institute (TWI, 2012) and the Setara Institute (Setara, 2012), have all shown that with Indonesia's newly found freedom it has also experienced growing challenges from intolerant groups, terrorist networks, and extremist militia groups. These groups have fuelled socio-religious tensions and violence, sectarian conflicts, and discrimination towards religious minorities, resulting in severe and on-going violations of religious freedom and human rights.

A number of specific events also point to a rise in religious discrimination. Following the 1998 reformation, conflicts erupted in many areas previously thought of as safe havens for diversity. Such was the case of a violent religious conflict that erupted in 1999 in the city of Ambon, on the island of Maluku. The conflict, which involved Christians (mostly Ambonese) and Muslims (mostly non-Ambonese), was triggered by an incident between a Christian public transportation driver and a local gangster (a nonAmbonese and Muslim). The conflict ceased in 2002 after claiming more than 2,000 lives (Sudjatmiko, 2008). Alongside these conflicts sprouting up across Indonesia, numerous bombings prompted by religious conflicts have also occurred. For example, in October 2002 a fierce bomb attack was conducted by the terrorist group Jemaah Islamiyah, where explosives were detonated in the Kuta nightclub district in Bali killing 202 people. This was deemed the world's deadliest terrorist attack since 9/11 (CNN, 2005). August 2003 saw a car bomb explode outside the Marriott Hotel in Jakarta, killing 14 people. The following year another car bomb exploded directly outside the Australian embassy in Jakarta resulting in nine deaths and injuring more than 180 people (Guardian, 2004). In 2005, Bali yet again suffered another bomb attack killing 23 people. That same year also saw the closure of 21 churches of various denominations, as a result of pressure by extremist groups on various grounds such as not having a legal construction permit (USCIRF, 2013). 
From 2006 to 2008 issues with the minority Islamic sect Ahmadiyya emerged. Viewed as heretics, many of their mosques were forced to close by radical religious groups, culminating in the joint decree of the Minister of Religious Affairs, the Attorney General and the Minister of Interior Affairs of banning the Ahmadiyya from proselytising (JP, 2013). President Susilo Bambang Yudhoyono has not only publicly supported religious tolerance and pluralism, but has vowed to protect religious minorities, with the government under him has taken an active role in counter-terrorism efforts. However, the government has also repeatedly sent mixed messages on its stance towards protecting religious minorities as it was under Yudhoyono's governance that a decree towards preventing Ahmadiyya activities was produced.

These examples of intolerance have coincided with the notable resurgence of Islamic identity among the majority Muslim population (Hassan, 2007). A 2006 survey conducted by the Indonesian Survey Institute (LSI) on Islamic radicalism showed Indonesian society's growing inclination towards the Sharia (Islamic based law) (LSI, 2006). Recently, a 2013 survey found that $72 \%$ of Muslims in Indonesia are in favour of making the Sharia the law of the land (PewResearch, 2013). The 2006 LSI survey also reported that there has been a growth of acceptance of extremist groups such as the FPI and FUI, higher than compared to liberal Muslim groups such as the Liberal Islam Network (JIL) (LSI, 2006).

The rise in conservatism in Indonesia is also reflected in youth demographics, where young Muslims in Indonesia are seen as both the targets and the agents of this Islamic resurgence (Parker \& Nilan, 2013). A 2010-2012 survey of 611,678 students and 2,639 teachers in the Greater Jakarta area (Jakarta and the areas surrounding it, namely Bogor, Depok, Tangerang and Bekasi) by the Institute of Peace and Islamic Studies (LAKIP) also reported indications that students were willing to participate in acts of religious violence (JP, 2012). Resistance to accepting inter- and intra-religious diversity among young people was also reflected in this survey, and evidence of growing religious intolerance among youths was found:

- 25.8 percent of students and 21.1 percent of teachers in Greater Jakarta 
deemed Indonesia's philosophical foundation the Pancasila (which comprises five principles emphasising a nation under God, unity, democracy, and social justice) no longer relevant.

- 48.9 percent of students were willing to be involved in acts of religious violence.

- 41.1 percent of students were willing to be involved in vandalising houses of worship of other religions. (JP, 2012)

While the government has addressed past sectarian violence and effectively curtailed terrorist networks, there still lies the task of tackling the intimidation, discrimination and violence towards religious minorities. The Indonesian government, including the local police, local officials and the courts, have been seen as incompetent in dealing with these issues as they have often tolerated the violent activities of radical groups (HRW, 2013). It continues to fail in upholding the national laws protecting religious minorities, and delivers lenient sentences to individuals engaged in this violence. In addition, national laws and provincial decrees have led to serious restrictions in freedom of thought, religion and belief; the destruction or forced closure of religious places; and imprisonment and persecution of individuals accused of blasphemy or deviant religious teachings (HRW, 2013; USCIRF, 2013).

Whilst these reports and surveys must always be taken critically and with much caution as not to envoke an alarmist view of Indonesia's socio-religious conditions, the numerous unresolved issues of these unsettling circumstances raise significant questions about the future of religious freedom in Indonesia.

To a degree, the government has acknowledged religious radicalism within Indonesia's society and has utilised a number of methods to maintain Indonesia's fragile unity. Aside from using (sometimes controversial) counter-terrorism strategies as a curative method of dealing with religious extremism, the government has also used education as a preventive method for not only countering religious radicalism, but also maintaining and preserving the imagined community. 
There have been very few previous studies concerning religious tolerance amongst youth and educational studies to examine what is occurring to address religious tolerance within schools in Indonesia. One large-scale survey was conducted by LAKIP in 2012 as previously mentioned, and another study by Parker (2008) researched an experimental inter-religious program within Indonesian schools. Yet both these studies have not examined how teachers' and students' identities inform their understandings and practices of religious tolerance. I will review these previous studies that has been done on religious education and tolerance in Chapter Three.

Indonesia uses both citizenship education and religious education in educating students in interreligious issues particularly in regards to religious tolerance. In Chapter Two I explore how Indonesia's citizenship education curriculum, states that students should tolerate and respect people of different backgrounds including religion. However, defining tolerance and how students should deal and manage with religious diversity is left to the job of the religious education. Yet in the last several years, the effectiveness of religious education in Indonesian classrooms has been challenged due to the emergence of a number of sectarian conflicts among Indonesians. Although these conflicts are rooted in religion is debatable the fact remains that the main targets of these conflicts were objects of religion. Although often the emphasis in Indonesia lies on Islam due to the growing religiosity of Indonesian Muslims, I contend that that this extends to all religion. Yet what these sectarian tensions suggests is a lack of respect of some people toward other religions (Zuhdi, 2005). In addition to this it is necessary to look for moral and philosophical basis that is acceptable to Muslims as it is fruitless to refer to authorities that they do not acknowledge (Daniel, 1993). Hence the importance of a religious education which may provide one way to deal with these issues by peaceful means. One key concept which underpins how many nations have worked toward achieving an ability to coexist as religiously diverse communities is that of religious tolerance. As it is a concept I will return to many times in this thesis. , In the following section, I will explore how it has been variously understood. 


\subsection{Understanding religious tolerance}

Scholars have argued that in realizing harmonious relationships, conversation and dialogue among traditions is important in order to achieve consensus (Kymlicka, 2001). This is needed due to the variety of values which every individual within society sees as worth living by and of which they may only choose some to live by (Appiah, 2006). However, "these values are shared by many great religions or faiths, and dialogue is needed to enable them to surface in people's awareness" (Raihani, 2011, p.26).

One value that most agree is need in order to live living together in religiously diverse society such Indonesia is that of tolerance. Tolerance concerns the rights of individuals. Locke (1983) claims that despite the conceptions of differentiating religious truth, every individual within a civil society is entitled to the right of worship of their chosen religion without being restricted by others. It is the separation of the religious and the socio-political sphere. As John Locke contends "No private Person has any Right, in any manner, to prejudice another Person in his Civil Enjoyments, because he is of another Church or Religion. All the Rights and Franchises that belong to him as a Man, or as a Denison, are inviolably to be preserved to him" (1983, p.31). It is with tolerance that individuals are required to respect each other's chosen religious path (Muldoon, Borgida, \& Cuffaro, 2011). Muldoon, Borgida \& Cuffaro (2011) further contend that forcing others to conform to our conception of the good, will not produce a virtuous outcome and thus the perspectives of others should be respected. Nord (1995) suggests that we need to understand others in order to make our own claim. He argues that:

... indeed, it is only when we can feel the intellectual and emotional power of alternative cultures and traditions that we are justified in rejecting them. If they remain lifeless and uninviting, this is most likely because we do not understand them, because we have not gotten inside them so that we can feel their power as their adherents do. Only if we can do this are we in a position to make judgments, to conclude, however tentatively, that some ways of thinking and living are better or worse than others. (p. 201)

Looking at Locke's argument on tolerance, it is easily understood why tolerance 
is needed to respect individual rights. Yet the problem of tolerance lies not within why it is needed but on how it is generally defined, as the limits and paradox of tolerance can be easily seen. As Parker (2008) points out, tolerance is not a very positive concept to begin with as it a shallow way of dealing with differences. Tolerance is often defined as forbearance (Oberdiek, 2001) patience with differences (Raihani, 2011), or enduring something we dislike (Muldoon et al., 2011). Newman (1982, p.4) defines tolerance as "to accept or endure that thing without reacting strongly to it. To tolerate it is to bear it, to put with it. It is not to like or respect it." This understanding of tolerance has been described by May (2006) as "only the kindergarten of the kind of interactive pluralism we now need, not only in democratic nation states but in the global civil society that is slowly but surely emerging" (p.11). Such definitions of tolerance are inadequate in dealing with the complexity of religious diversity. Tolerance needs to go beyond mere forbearance of the things that are disliked; as with this definition it does not promote actual dialogue between citizens it is merely restraining one's self when confronted with religious issues. Through dialogue citizens are able to negotiate the different perspectives of others and integrate these different perspectives to one's own actions (Miedema, 2006).

Tolerance should encompass values of respect and recognition as through these, citizens may develop a deep appreciation for and respect of differences, based on the principle that all human beings have equal rights (Raihani, 2011). For this reason, Jackson (2007) suggests that alongside tolerance, respect and recognition are essential components and will help strengthen equalities by accommodating differences between the different groups. "With tolerance, respect, and recognition, active participation and mutual contribution can be expected from each of the members of society in the context of harmonious relationships" (Raihani, 2011, p.25).

Jackson and Raihani's position of a more inclusive and expansive notion of religious tolerance and pluralism underpins the approach taken in this thesis. This understanding sees pluralism as more than tolerance - it is "an active seeking of understanding across lines of difference. Pluralism is not relativism; it does require leaving identities behind. Yet it requires accepting the rights of others, the right to design 
one's own life, the right to be different' (Introduction to Promoting Pluralism Knowledge Programme at www.hivos.net, cited in Bagir (2009)). Education for religious tolerance is an important aspect of the Indonesian curriculum, and that of many other nations. But just how successful is it and what is happening in schools in regard to this?

Seeing the emerging problems of religious radicalism and the minimal studies conducted in this area, it is appropriate to put in place some research to examine further how the teachers and students perceive their sense of identity and their perceptions of religious tolerance and citizenship. One interesting point to take into account is a claim by Leirvik (2004) who holds that, "the latest revision of the Indonesian national curriculum may point in the direction of a more unifying vision that stresses the civic dimensions of religious education" (p.228). Raihani (2011) also suggests that the national curriculum attempts to connect individual religions with the citizenship values such as tolerance and good interfaith relations. Yet as Sim (2012) has noted, it would be difficult to understand the actual illustration of citizenship education without understanding inclassroom events, remembering the "value-laden nature of the citizenship curriculum" (p.221). What we know very little about is what this looks like in Indonesian schools and classrooms, how teachers can shape this and how students respond to this education.

\subsection{Research aim \& questions}

The aim of this research is to investigate the perceptions of teachers and students towards religion, citizenship, identity and religious tolerance as outlined in the following research questions:

RQ 1: What are the perceptions of secondary schools teachers' and students' towards religion, citizenship and identity?

RQ 2: What are the perceptions of the teachers and students towards religious tolerance? 


\subsection{Personal incentive for research}

As a non-Muslim, I am effectively a minority in Indonesia. I've become acutely aware of the growing tension between Muslims and non-Muslims, which I assumed was the result of the growing Islamic conservatism in Indonesia. This growing religious conservatism affected Indonesia in a myriad of ways. Conflicts between Muslims and non-Muslims in areas once peaceful; some religious sects persecuted sometimes to a deadly extent; the growing conservatism of local laws and a growth of intolerance spreading across the nation: yet the Indonesian government was adamant that Indonesia has only minor interfaith issues. Personally, I have not experienced any form of discrimination in the society around me - however, this may be due to my limited experiences in engaging with conservative Muslims.

I first became interested in interfaith issues when I was conducting my undergraduate degree in International Relations in Indonesia. During that time I learned of the post-9/11 world where it seemed Samuel Huntington's conviction of a world undergoing a clash of civilizations might possibly become true (Huntington, 1996). Media outlets provided a grim picture of the inter-faith and intra-faith conflicts happening throughout the world.

My interest in interfaith issues grew further when I became a teacher at a primary school. In my short time as a teacher, I learned how the school tried to conduct a more open and progressive approach to religious education. The school repeatedly stressed religious tolerance as a way of coping with difference and had a specific school subject to discuss this. This experience as a teacher triggered my curiosity as to how religious tolerance is perceived by teachers and students alike. My intention is that the findings of this research will help inform and shed light on the development of religious tolerance and citizenship in Indonesia's schools.

\subsection{Thesis structure}

The thesis is structured as follows: 
Chapter Two provides a contextual background on the current state of religious freedom in Indonesia. In addition, this chapter also elaborates on the schools and the religious and citizenship curriculum. The literature review and theoretical framework in Chapter Three begins with exploring definitions of citizenship and identity, and examines the social constructivist approach used in this thesis. Chapter four elaborates on the qualitative case study methodology used for this research. I have also provided a detailed description of each of the case study schools in this chapter.

The findings of my research are provided in Chapters Five and Six. Chapter Five analyses teachers' and students' perceptions of their citizenship, religion and identity. This chapter looks at the participants' perceptions of their personal identity, how they view religion in the context of socio-daily life and also explores how participants form their moral values. Chapter Six examines teachers' and students' perceptions of religious tolerance, including how they define and value religious tolerance. Furthermore, this chapter looks at the concerns of participants regarding teaching and learning religious tolerance.

The discussion in Chapter Seven explores the key findings in greater depth, as it looks how participants intertwine their national identity and religious identity, producing what is known as religious citizenship. In addition to this, Chapter Seven looks at issues concerning inter-religious education within the schools.

The final chapter concludes the thesis with a reconsideration of the findings, providing several conclusions, along with suggestions for further research in the area of inter-religious education. 


\section{CHAPTER 2: CONTEXTUAL BACKGROUND OF RESEARCH}

\subsection{Introduction}

This chapter begins with a brief outlook of Indonesia's rationale on religious freedom, including the laws governing it. It then examines the development of Indonesia's national curriculum and Islamic schools. This section also briefly looks at the development of citizenship and religious education in Indonesia.

\subsection{Freedom of religion in Indonesia}

Despite the growth in religiosity and radicalism as briefly elaborated on in Chapter One Indonesia is not a theocratic state. Indonesia prides itself in being a free and democratic country and supports the freedom of religion as based on its 1945 Constitution. That said, there are officially only six religions acknowledged in Indonesia. With an estimated population of over 240 million, $88.1 \%$ of the population follow Islam, 6.1\% follow Protestantism, 3.1\% Catholicism, 1.79\% Hinduism, $0.61 \%$ follow Buddhism, with Confucianism being an officially recognized religion since $2006(0.10 \%)$ and local beliefs constitute a very small percentage (BPS, 2010). A majority of Indonesian Muslims follows the Sunni denomination, while a minority follows Shiah and Ahmadiyya.

Indonesia is not a theocratic state but the first of five principles of Indonesia's ideology, the Pancasila, explicitly states, "belief in one and only God", This indicates the state's interest in religion as a means of strengthening national identities (Parker, 2008; Pohl, 2011). Furthermore, Parker (2008) also argues that with this first principle of the Pancasila, Indonesia is neither a secular state nor an Islamic state, but it is a religious state. It is the Pancasila's first principle that provides Muslims with a basis for directing the state of Indonesia toward a more Islamized form (Ropi, 2012). This first principle of 
the Pancasila was given further legislative force when it was included in Article 29 of Indonesia's 1945 constitution, a revised version of which continues to regulate Indonesian religious affairs today. Article 29 states that, "The state shall guarantee freedom for every citizen to embrace any religion or belief and to practice religious duties in conformity with that religion or belief." However, only the six religions mentioned earlier can be written in the religion section of the national identity card or colloquially known as the KTP (Kartu Tanda Pengenal), due to an archaic law - No.1/PNPS/1965.

Law No.1/PNPS/1965 came about on January 27, 1965, as a response to the growing tension between Muslims and spiritual groupings, the late President Soekarno issued a Presidential edict on "Religious Defamation" which remains in force to this day (Hefner, 2013; 2013). The law, concerning Prevention of the Misuse and/or the Defamation of Religions in itself, states two aims; the first of which was to ensure national security, the goals of the revolution and national development, where the misuse or defamation of religions was seen as a threat to these goals. The second was to prevent the growth of local beliefs and spiritual sects or organisations that were seen to have similar traits towards the accepted religions, such as the minority Shiah Muslim denomination or the Ahmadiyya Muslim sect. Law No.1/PNPS/1965 outlines the religions adhered to in Indonesia, namely Islam, Catholicism, Protestantism, Buddhism, Hinduism and Confucianism, but states that other religions are not prohibited in Indonesia as long as they do not violate this law. Yet in practice, this law has been interpreted to mean that only six religions are recognised in Indonesia, resulting in the usage of the term 'official religions' in subsequent human rights policy and legislations (Colbran, 2010). Moreover, the Ministry of Religious Affairs is structured in a way that reflects this interpretation, having directorates for each of the six 'official' religions (Colbran, 2010). On these accounts it can be said that with this law the state is authorized to determine not only the definition of religion but also who has a 'religion' and who does not, occasionally producing a narrow definition of religion (Colbran, 2010; Hefner, 2013)

The No.1/PNPS/ 1965 law has been used on numerous occasions since its inception towards 'deviant' beliefs or religions in many cases, throughout Indonesia. For instance the Ahmadiyya and Shiah Muslims sect was deemed to be deviant as such 
religious expressions were not along the lines of the accepted and predefined definition of Islam in Indonesia, thus justifying the discrimination, hostility and violence towards these adherents. The narrow definition of what constitutes as a religion, as the result of the Law No.1/PNPS/1965 not only has had a detrimental effect on the freedom of religion in Indonesia, but also complicates matters of religious tolerance which are the crux of maintaining Indonesia's religious freedom. Religious tolerance is therefore limited to the government defined religions as which are then reinforced by the law. Followers of indigenous religions, known as 'unofficial religions', are often labelled as deviants, heretics or blasphemous and are forced to return to the 'official religion' or they will be charged of disturbing public order or of defaming official religions (Colbran, 2010; Hefner, 2013; HRW, 2013; TWI, 2012). Current followers of such beliefs are put under the supervision of not the Ministry of Religious Affairs, but the Ministry of Tourism and Creative Economy, regarding their beliefs as a cultural heritage rather than a religious per se.

The problem of religious tolerance in Indonesia is a complex matter to begin with as it is incontestably tied with issues of religious freedom. As the report by the Human Rights Watch (2013) suggests, the Law No.1/PNPS/1965 has given rise to violations of civil rights and a chance for radical religious groups to conduct injustices. Colbran (2010, p. 695) further asserts, "this law also means that legal instruments and policies protecting freedom of religion or belief only protect followers of recognised religions." Through Law No.1/PNPS/1965, Indonesia has the authority to limit the freedom of religion of its society and thus has perhaps wilfully dictated how tolerance is defined and to whom it should be directed at. Using this authority over the society's religious freedom, the state then reinforces this notion of religious freedom through various policies including education policies.

\subsection{Indonesia's education system}

This section will provide a brief historical and contextual background on the development of Indonesia's education system and in particular its curriculum. Education 
in Indonesia is under the responsibility of both the Ministry of Education and Culture and the Ministry of Religious Affairs. This is due to the presence of a significant number of Islamic schools which are managed with the collaboration of both the Ministries in Indonesia. There is a nine-year compulsory education in Indonesia that all citizens must take; this consists of six years at elementary level and three years in secondary level. Schools in Indonesia are run either by the government (negeri) or private sectors (swasta). According to law no.2/2003, education (Kemendikbud, 2003) is defined as:

A conscious and planned effort to actualize a learning environment and a learning process in order for the students to actively develop his/her potential to gain spiritual and religious strength, self-control, personality, intelligence, a noble character and creative skills which are needed by him/herself, the society and the nation. (p. 4)

This statement shows just how closely religious education is embedded within education system and the development of the "good" citizen.

\subsubsection{Contextual background of Indonesia's national curriculum}

In the years following its declaration of independence in $17^{\text {th }}$ of August 1945, Indonesia endured a series of political transitions, at times violent. Throughout these transitions, Indonesia has also revised its curriculum to parallel the changing sociopolitical dynamics of the nation. These changes indicate the socially constructed nature of curriculum (Apple, 2004). These revisions occurred in 1947, 1952, 1964, 1968, 1975, 1984, 1994, 1999 (supplement), 2004, and 2006. The most recent revision 2013 is still undergoing trial run and has not been implemented throughout every school in Indonesia and therefore won't be examined in this thesis. These years indicating a new curriculum also mirror a much wider change in Indonesia's society. These revisions are a logical consequence of changes that have happened within the society, ranging from the political system to the socio-economic-cultural situations within that particular time.

The first curriculum, known as Leer Plan 1947 (Subject Plan 1947), reflected Indonesia's newly gained independence and the birth of a new country. It was still highly influenced by the prior colonization of the Dutch and the Japanese which can be seen by 
its attempt, to develop conformity and to establish and instil newly formed Indonesian values, specifically:

1. Awareness towards the nation-state (i.e. ideologies, constitution, citizenship concepts, etc.) and the society on which they daily interact with.

2. schools subjects that are connected with daily events.

3. emphasis on arts and physical education. (Dikti, 2012, pg.71)

In 1952 Indonesia overhauled its' curriculum and developed a more improved curriculum known as the Leer Plan Terurai 1952 (Unravelled Subject Plan 1952) where it tries to break its ties with the education system of it colonizers (Dikti, 2012). This was partially a response towards the second Dutch Military Aggression of 1948 and the resulting international agreements between Indonesia and the Netherlands concerning Indonesia's sovereignty (Dikti, 2012). This curriculum included lesson plans which had to consider the content of subjects connected with everyday daily life such as farming, and also developing nationalistic values as an Indonesian citizen. According to law No.4/1950 which discusses the foundations of education and teaching in schools, "the purpose of education and teaching is to shape an adequate human being and a democratic citizen of whom is responsible for the welfare of it society and nation" (pg. 1).

Indonesia tried to further improve the national curriculum, with its Education Plan of 1964. This curriculum tried to deliver a more holistic form of a curriculum with five fields of study; moral values, cognitive development, emotional/artistic sense, daily skills and physical education (Dikti, 2012). One of the main reasons for this curriculum development was the growing interaction Indonesia had with the global world and its desire to become a leading nation within the global community (Dikti, 2012). This was expressed constantly by Indonesia's president of that time, President Soekarno, by deploying an anti-western stance and frequently sided with communist nations such as China and the Soviet Union. Alongside this tight bond between the communist countries Indonesia also had the largest communist party in the non-communist world (Mortimer, 1974).

Following the failed military coup of $30^{\text {th }}$ September 1965, the Communist Party 
was blamed as the mastermind of the failed left-wing coup, Indonesia's socio-political situation changed dramatically and President Soekarno was ousted and replaced by President Soeharto. The year 1968 saw a new curriculum to cope with the changing socio-political conditions of that time. It was in essence a transition curriculum that was implemented to replace the 1964 curriculum from the "Old Order" (President Soekarno) to the "New Order" (President Soeharto) (Dikti, 2012). The 1968 curriculum was built on the Pancasila, Indonesia's philosophical-values foundation, focusing more on theoretical knowledge and less on practical skills that were dominant in previous curricula.

The curriculum also became exceedingly anti-communist, reflecting the anticommunism efforts conducted by the government of the New Order as a reaction against the failed coup. As communism was analogous with atheism or godlessness, the result was profound for the state religiosity in Indonesia. People flocked to have a religious identity in accordance with the national laws, meaning many converted their religion to the ones acknowledge by the government at that time, leaving local religions and beliefs behind and with this religion became a public matter (Kuipers, 2011). As the curriculum was seen to focus too heavily on theoretical knowledge, lacking any practical skills, the curriculum was revised again in 1975. This curriculum was characterized by a goaloriented approach and the confessional model instructional system known as the Development Procedure of Instructional System (Dikti, 2012).

During the New Order, Indonesia's main method of dealing with ethnic and religious diversity was largely to pretend it did not exist (Kipp, Smith, \& Rodgers, 1987). It did this by producing the acronym SARA: "To encapsulate the four sensitive areas that could not be discussed in public" (Hefner, 2013): ethnicity (suku), religion (agama), race (ras) and interclass (antar golongan) differences. This method of managing plurality is still being used by the society and currently emphasized within the curriculum.

The 1975 curriculum was criticized for the heavy content load the number of curriculum content being taught and the ability of the students to absorb the materials. The 1984 curriculum was constructed as a response to these critiques, the growing Indonesian economy and the demands of science and technology as Indonesia's growing 
economy pushed for the procurement of new courses to meet the needs of the increasingly diverse employment opportunities (Kuipers, 2011). One of the major alterations of this curriculum was its teaching approach which was based on a student's active learning system that theoretically provides the opportunity for students to actively engage the physical, mental, intellectual, emotional capabilities. However, by 1994, this emphasis on the theory of learning was seen to undermine a focus on content.

The 1994 curriculum tried to address this problem by changing the length of study from the semester system to the quarter-semester system. As briefly elaborated in Chapter One, following the Asian monetary crisis of 1997 and the reformation era of 1998 which resulted in the downfall of the 32 years of the New Order government and subsequently of President Soeharto, Indonesia was stirred by ethnic-religious violence. The changing socio-political conditions once again pushed the national curriculum to adapt. With the change of the government and political system due to the 1998 reformation, a supplement was added into the 1994 curriculum. The purpose was to address the change of citizenship education, to give a greater emphasis on values of democracy and human rights (Dikti, 2012). No longer was it a form of state indoctrination, the students were encouraged rather than enforced to learn of Indonesia's citizenship values where it derives from the Pancasila (Samsuri, 2012). I will elaborate further on this in a section below.

The period after the 1998 reformation Indonesia's economy deteriorated dramatically due the political instability following the reformation and also due to the Asian monetary crises that fuelled the reformation. The government in turn with the support of the private sector tried to improve the quality of Indonesia's education system in order to be better prepared for an uncertain economic future. The 2004 curriculum was based on the competency-based education system - known as the Competency-Based Curriculum (KBK). This curriculum was geared towards preparing the students to identify their personal competency so that they may engage more fully and more resilience for a diverse and often uncertain economic future as stated in law no.20/2003 concerning the national education system. The curriculum subjects were not vastly different from the 1994 curriculum but the emphasis changed on how subjects were 
taught. Students were encouraged to critically think rather than just merely conduct rote memorization. This however led to problems in testing the effectiveness of the method and also the knowledge the students were achieving due to the reduction in the teachers' role in providing knowledge (Dikti, 2012).

The most recent curriculum that is currently being implemented in schools throughout Indonesia is the 2006 curriculum. As Indonesia's economy slowly picks up following the Asian monetary crisis and tries once again become one of the major players in the global economy, and also with an increasingly stable socio-political situation, the 2006 curriculum was formed. This was in essence the 2004 curriculum with changes that strived for a more effective, efficient and foreseeable output. One of the chief differences of this curriculum was the encouragement of diverse, interactive and engaging forms of learning, to promote personal competencies while at the same time teachers still play a vital role in instilling knowledge (Dikti, 2012).

This short elaboration of the development of Indonesia's national curriculum applies for all schools within Indonesia. However Islamic schools have an additional Islamic curriculum aside from the national curriculum to cater its religious needs. I will further elaborate on the development of the Islamic schools curricula in section 2.3.2.

\subsubsection{Contextual background of Islamic schools}

Aside from religious education, the Ministry of Religious Affairs (MORA) with the Ministry of Education and Culture (MOEC) also oversees Islamic schools. Recently, due to the rising radicalism, Islamic schools have been scrutinised and accused of producing radical Muslims (Parker, 2008; Parker \& Nilan, 2013). Although there have been cases of these radical schools, they remain few and far between as most Islamic schools are seen as moderates (Parker \& Nilan, 2013; Zuhdi, 2006)

An Islamic school is defined as a formal education institution in which Islam is the only official religion being taught. The schools has an additional curricula aside from the national curricula that studies Islamic teachings more in depth compared to the nonIslamic schools (Kuipers, 2011; Zuhdi, 2006). After its independence in 1945, Indonesia 
initially only had an existing educational institution that could be categorized into two groups: religiously affiliated and non-affiliated schools (Zuhdi, 2006). When the first Indonesian government established its national education system, they only funded the secular system which caused some resentment by the Muslim majority as the vast number of Islamic schools only received minimal government support, even as they continued to educate a great number of Indonesian children. (Kuipers, 2011). However, this did not mean that the government did not give attention to these schools. Yet as Zuhdi (2006) states, it was the Ministry of Religious Affairs (MORA) instead of the (in full if first time using) MOEC that supervised the schools, as they were religious oriented.

Currently Indonesia has three types of formal Islamic schools: first, the pesantren, which is a religious boarding school where with their traditional values maintain a greater emphasis on its Islamic teachings often geared towards producing religious leaders or imams. Second, the Madrasah, a religious day school, these provide an in depth learning of Islamic teachings and would often base its secular subjects on religious teachings. Last, the sekolah Islam, a day school that balances secular curriculum and religious teachings.

As discussed above, up to the 1970s, Islamic schools were initially somewhat neglected by the government. By 1950, Islamic educational institutions were partially recognized by the state through Law no. 4/1950 which discusses the education and teaching in schools within Indonesia. Article 10 of this law states that in order to receive recognition from the Ministry of Religious Affairs, the school must provide religious education as core curriculum subjects at least six hours per week on a regular basis in addition to general subjects. Islamic schools were given formal recognition from the government in 1975 through the creation of the three-minister decree concerning the status of the Islamic schools specifically the Madrasah (Zuhdi, 2006).

According to the 1975 decree, the composition of Madrasah's curriculum to comprise $30 \%$ religious instruction and $70 \%$ non-religious subjects, including languages, citizenship, social studies, math, natural sciences, arts education. In 1989, the government produced the National Education Act, the first act that explicitly referred to 
the Madrasah as part of Indonesia's national education system. The main reason for the inclusion of Islamic schools as part of the secular education system was the country's long history of 'Islamization' and the role that Islamic education had played throughout the country's history (Kuipers, 2011; Zuhdi, 2006).

According to Ministry of Religious Affairs (MORA) there are about 7 million students registered in a Madrasah ranging from the kindergarten to high school, yet only about 890, 000 students are registered in a Madrasah high school (Kemenag, 2009). This is miniscule compared to the 6.8 million students enrolled in non-Islamic high schools throughout Indonesia (Kuipers, 2011). Much like its non-Islamic counterparts, Madrasahs consist of Radhatul Athfal (RA) or kindergarten, Madrasah Ibtidaiyah (MI) or elementary school, and Madrasah Tsanawiyah (MTs) is the equivalent to junior secondary school. Madrasah Aliyah (MA) is the equivalent to senior secondary school while Madrasah Aliyah Kejuruan (MAK) is the equivalent of senior secondary vocational school. One such school was a selected as case study for this research, the Jakarta Madrasah High.

\subsubsection{Contextual background of citizenship education and religious in the national curriculum}

Between 1973 and 1998, the form of education on how to shape the nations' citizens was entrusted towards various subjects and from citizenship education formulized into the Pancasila education. There have been variations of Pancasila education but it can be summed into two major subjects: Pancasila Moral Education and History of the National Struggle (Lydersen, 2011; Samsuri, 2012). Pancasila Moral Education (PMP) focused on character education and education in the state ideology. The History of the National Struggle looked at 350 years of national history as a continuous struggle of the state against enemies, externally (various colonizers) and internally (communists and regional separatists). However with the introduction of a new

curriculum in early 1999, some specific lessons were removed from the Pancasila course (Levinson \& Sutton, 2008), although the current text books still do not closely examine the alleged failed 1965 communist coup. According to Samsuri (2011), both forms of 
citizenship education have been conducted through a top-down approach. This means as if the citizens do not have the authority to define what it means to be part of a nation as the concept of citizenship is constantly defined and reiterated by the government. However Levinson and Sutton (2008) argue that there has been two important moves by the Ministry of Education and Culture (MOEC) that shows the progressive nature in establishing citizenship:

Moved from a detailed scope-and-sequence curricula, to curriculum frameworks that are meant on the one hand to provide for "outcomes based" education and, on the other, to allow for local autonomy in the development of specific curricular material (p.142).

With this recent development in citizenship education within the 2006 curriculum, citizenship education has been given more freedom in defining citizenship.

As previously explained Indonesia has always had a close bond with religion. After Indonesia's independence in 1945, religious education became a high priority matter for the government, both in non-Islamic schools and Islamic schools. Religious Education is specifically governed by Law No.4/1950 on Chapter XII of Article 20, namely:

1. In public schools are held religious instructions, yet the parents determine whether their children will follow the lessons or not.

2. The implementation of religious education in public schools is determined by the regulations set by the Ministry of Education, Teaching and Culture, together with the Minister of Religious Affairs.

The development of religious education after the independence is strongly associated with the role of the MORA, which was officially established on January 3, 1946. The Ministry of Religious Affairs as a government institution conducted intensive political struggle for religious education in Indonesia, as Indonesia was in nature secular (Zuhdi, 2006). The task of MORA was to provide religious instruction in public schools, 2) to provide general knowledge at the Madrasahs, and 3) to conduct religious teacher's education and Islamic affairs magistrate education (Department of Religious Education, 
1956, p. 1). . As explained briefly above, during this time religious education was not compulsory for students. However with the effects of the failed communist coup in 1965 spreading throughout Indonesia and a fear of a communist resurgence in the future, a new law was produced. That law was Article 4 of TAP MPRS No. XXVII/MPRS/1966, which redefined the purpose of education to the following:

1. To enhance the mental, moral, character and to reinforce the belief in religion

2. To enhance intelligence and skills

3. To foster and develop a strong and healthy physique

With this new law, religious education became compulsory in non-religious schools. Alongside Pancasila, Moral Education, and religious education became one the key educational policy strategies to help Indonesian children and young people to learn to live together within a religiously diverse Indonesia. However, in the last several years, the effectiveness of religious education in educating necessary values has been challenged due to the emergence of a number of conflicts across the archipelago (see Chapter One). While it is debatable whether the causes of these conflicts were solely religious, they have often been manifested as religious-related issues. This may imply a lack of tolerance of some people toward other religions. Yet as the first principle of the Pancasila is known as Ketuhanan Yang Maha Esa ("Believe in one God") which the country upholds and adheres to, religious education will still remain an important part of Indonesian schools. In the following section I will briefly examine the Religious and Citizenship education curricula in more detail.

\subsection{The current Indonesian National Curriculum: Religious and Citizenship Education}

The purpose of the national curriculum is to prepare Indonesians so that they may acquire life skills as a person and as a citizen that is religious, productive, creative, innovative, affective, and are able to contribute to the society, the nation and the civilization of the world (Kemendikbud, 2003). This curriculum addresses issues of 
diversity by emphasising the need for tolerance in both the religion and the citizenship curricula; however, it also constantly refers not only secular foundations but also touches on the theological framework in defining religious tolerance. In examining Islam and citizenship, (Pohl, 2011) contends that a theological framework is needed as a basis in which the "ideas and principles of tolerance and pluralism could be discussed from within the Islamic tradition." Pohl sees this as the only viable method in which inclusive values, such as tolerance and pluralism, can be accepted by the Islamic community. Yet the religious education curriculum does not only utilize a theological framework for learning Islam but also other religions as well (BSNP, 2006). The religious education curriculum is divided into sections based on the six acknowledged religions in Indonesia. For instance, for Muslims students in grade 11, one of the basic competencies is tolerance and the curriculum specifically states that one should refer to the Quran by analysing Qur'an chapter 10: verse 40-41: "And of them are those who believe in it, and of them are those who do not believe in it. And your Lord is most knowing of the corrupters." It further states on referring to Qur'an chapter 5: verse 32:

Because of that, we decreed upon the Children of Israel that whoever kills a soul unless for a soul or for corruption [done] in the land - it is as if he had slain mankind entirely. And whoever saves one - it is as if he had saved mankind entirely. And our messengers had certainly come to them with clear proofs. Then indeed many of them, [even] after that, throughout the land, were transgressors.

Other religions are treated in a similar fashion, as tolerance seen from a Protestant perspective in the curriculum (BSNP, 2006) states:

- It is to behave kindly by valuing one another human being of which we are all created in the image of God thus we are all brothers and sisters.

- It is to behave caringly towards values of justice, truth, peace and the integrity of creation based on the teachings of Jesus Christ.

- It is to behave with the love of peace towards the plurality of Indonesia as a gift from God.

- It is to be proactive in dialogue and cooperation with other religions. 
In addition to the definition of religious tolerance defined in the religious education curriculum, the citizenship education curriculum defines its standings on religious tolerance from a secular perspective, i.e. the constitution and laws concerning human rights and religious freedom. It does so by educating and urging students to learn and carry out the laws within the constitution, specifically in article $28 \mathrm{E}$, which states:

1. Every individual is free to embrace any religion and worship accordingly to their religion, to choose an education, to choose a job, to choose a citizenship, to choose where to live in the confines of the national boundaries, to depart from that place and to return.

2. Every individual has the right to freely believe in any faith, to express his/her thoughts and attitude in accordance with his/her conscience.

3. Every individual has the right of freedom in a union, to assemble and to express opinions. (Article 28E of the Indonesian Constitution)

In addition to this, Article 29 of the Constitution also states:

1. State is based upon the belief in one supreme God.

2. The state guarantees the freedom of each citizen to embrace each religion and to worship according to his/her religion or belief.

The usage of a theological framework and a secular basis as an underpinning in defining religious tolerance shows how the state tries to find a middle ground in which religion and secular laws can work together. The state hopes to produce a concept of citizenship that may draw upon both religious and secular laws in defining its values. With this the state tries to not only appease both the religious and nationalist-secular citizens but also seeks to have the various religions within Indonesia co-exist with one another yet with a theological framework as the basis to it. This is done by having them draw on their religious laws, which they can more easily accept as they are based on their religion's theological framework, and not through secular laws. Seeing the growing religious intolerance and radicalism develop not only among adults but also among youths, it is necessary to conduct research into the outcomes of the government's educational efforts in curbing these issues, as religion has and will continue to be a vital part of Indonesia's society. 
Although citizenship education has largely been seen as a tool for developing national cohesion it has done so by the means of indoctrination of the regime`s values and ideas. The end result is new opportunities for a broader and more inclusive notion of citizenship thus a reason for further research in this area.

\subsection{Conclusion}

This chapter has discussed the current condition on how Indonesia views religious freedom, the contextual background of the religious and citizenship curricula and also of the Islamic school. In summary, the development of the curriculum is based on the socioeconomic and political changes that occurred prior to the curriculum revisions. In order to examine how teachers and students define and understand identity and citizenship, the next chapter reviews past literature in these areas and looks at the concept social constructivism as a framework for this thesis. 


\section{CHAPTER 3: LITERATURE REVIEW AND \\ THEORETICAL FRAMEWORK}

\subsection{Chapter Introduction}

In this chapter I will provide an account of citizenship, identity and inter-religious methods as discussed in relevant literature. This chapter begins by giving a description of citizenship and identity, and will also look at religious citizenship. Section 3.3 will discuss several inter-religious methods, including concepts of religious tolerance. This section will also briefly look at inter-religious education within Indonesia. Section 3.4 will look at the theoretical framework that underpins this research, namely social constructivism.

\subsection{Prior studies of religious education and tolerance}

There have been a number of studies on the practice of inter-religious education including the use of tolerance within schools and among youth in Western countries. For example, research conducted in Northern Ireland examined the impact of integrated and segregated education on the relations between Catholics and Protestants and found that segregated religious schools may heighten the divisions between the different religious communities rather than help alleviate tensions and intolerance between them (Hayes, McAllister, \& Dowds, 2013). A further study conducted in various schools throughout Europe showed the positive results of educating tolerance through confronting diversity (Dobbernack \& Modood, 2012). This study further states that tolerance is a much-needed value that must be educated for as the European countries are increasingly becoming more diverse, not only in religion, but also in culture and ethnicity (Dobbernack \& Modood, 2012).

However, although religious tolerance has been the subject of much debate and research in Western countries, studies of tolerance of non-Muslim faiths in predominately Muslim countries are rare (Al Sadi \& Basit, 2013). One study conducted in a 
predominantly Muslim country, Oman, suggests that educating students of other religions resulted in greater tolerance towards differences compared to those who did not receive such an education (Al Sadi \& Basit, 2013). Studies of inter-religious education and/or religious tolerance in Indonesia alone have been scarce. A large-scale survey that was conducted by LAKIP in 2010-2012 examined the perceptions of students and teachers towards individuals of different religious backgrounds. In addition to this, Parker (2008) has done a small-scale study on two schools in Indonesia both uniquely utilizing a more inclusive method in educating inter-religious education. The first school being a private Catholic school and the second an Islamic school both situated in Yogyakarta. Both schools applied an inclusive form of inter-religious education by providing the students not only the prospects of tolerating other individuals of different religious backgrounds but expanding the notion of inter-religious relationship towards also accepting the differences as well. These two cases however are mere experiments and are rarely, if not at all, enacted in other schools (Parker, 2008). These previous studies informed my study by giving some insights into what is happening in schools and with Indonesian youth and also pointed to the importance of actually entering different classrooms and schools to see what is happening in such places in response to growing challenges of religious pluralism.

\subsection{Descriptions of citizenship and identity}

Citizenship has frequently been tied to national identity and/or belonging. In Anderson's (1991) view, national identity has often been limited to a group of people who are defined as belonging to an imagined national community that is constructed through a national discourse. This imagined community sets the criteria for inclusion and exclusion, thus forming a national identity. Anderson elaborates: "it is imagined because the members of even the smallest nation will never know most of their fellow members, meet them, or even hear of them, yet in the minds of each lives the image of their communities" (1991, p. 5). In this way national identity can be viewed as a shared phenomenon that unites people as a nation (Korostelina, 2007). Kelman (2001) provides a deeper definition of national identity: 
Insofar as a group of people have come to see themselves as constituting a unique, identifiable entity, with a claim to continuity over time, to unity across geographical distance and to the right to various forms of self-expression, we can say that they have acquired a sense of national identity. National identity is the group definition of itself as a group-its conception of its enduring characteristics and basic values; its strengths and weaknesses. (p. 191).

National identity is constantly reconstructed to serve several functions: to provide a sense of uniqueness and unity as well as a sense of belonging to group members; to develop a positive self-image; to offer a basis for cultural development, religious beliefs, and way of life; and to grant the foundation for ownership of land and resources (Kelman, 2001). Korostelina (2007, p.182) explains that the acquisition of national identity depends on several components: "shared beliefs, values, assumptions, and expectations". She adds that the membership of a nation is not based on similarities but feelings of strong attachment to the nation, and solidarity among its members. Osler and Starkey (2005) expands on this by arguing that citizenship has three essential and complementary dimensions that are intertwined with one another, namely, status, feelings and practice. They suggest that the focus of citizenship often lies on the status of the individual, neglecting the need for feelings and for the individual's active participation in the society. Citizenship requires more than a legal status, though it is an essential first step (Banks, 2007). Banks further observes:

Becoming a legal citizen of a nation-state does not necessarily mean than an individual will attain structural inclusion into the mainstream society and its institutions or will be perceived as a citizen by most members of the dominant group within the nation-state. A citizen's racial, cultural, language, and religious characteristics often significantly influence whether she is viewed as a citizen within her society. (p.5)

As a result, although states constantly try to impose a particular identity, the ability to identify with the state varies among citizens. The problem, as Banks suggests above, lies in whether the state treats its citizens equally. Experiencing inequality may affect how the citizens identify themselves in relation to the state. This personal experience of identity will be put into context of the data in chapter six, when discussing 
the identity of the participants and their experiences.

Burke and Stets (2009) depicts how individuals hold different identities or have multiple identities. Although individuals have multiple identities, this does not mean that those identities are either static or constantly changing. Instead individuals maintain a fairly similar set of identities that are dependent on the social context (Ross, 2007). Additionally, conflicts may arise if the identity chosen by an individual is incompatible with the majority identity which is constantly imposed and constituted by society (Kelman, 2001). This in itself, as mentioned above by Osler and Starkey, may be entwined with a citizen's active participation in the society. However, this poses yet another problem as Miller (2000) explains:

We may share a common legal status, a formally-defined set of rights and obligations, but how can we agree about what it means to be a citizen, what rights and obligations ought to be included in the legal status, and beyond that how we ought to behave when occupying the role of citizen? (p.41)

What Miller queries is the nature of the social framework that should guide how citizens work with each other and actively participate in society. What he is describing is the need for a set of citizenship values to provide a reference point which guide individuals and groups with fragmented identities to find a way to live together politically. It is the expression of values, where citizenship might be a form of behaviour rather than a status upon which to demand rights or entitlements (Irving, 2007). Through citizenship, a nation can reassert moral values and social responsibility for the good of the community (Miller, 2000). However, since citizenship is a 'collectivist' concept Splitter (2011) warns of its dangers:

Collectivism, in its most extreme form imposes a strict categorization on persons, so that their own sense of identity is consumed-completely defined-by the group. In danger of being lost here is not only the individual's sense of himself as an individual but-and this is the second point-his sense of himself as a member of various other groups at the same time (p.488).

This is what Amartya Sen calls the 'Fallacy of Singular Affiliation', which he sees as 
being at the core of much of the intolerance in the world today (Sen, 2007). The Fallacy of Singular Affiliation particularly afflicts 'large' groupings such as culture, race, nationality and religion. Splitter (2011) further suggests that the reason for this "is that their 'largeness' consists, not merely in their size, but in the extent of their claims on our allegiances and life-stories" (p.488). As an alternative to this 'singular affiliation' there needs to be a negotiation between the multiple identities of citizens in order to find the common ground between them. This understanding underpins the approach taken in this thesis, in which I seek to explore how multiple identities can find a way to live together in Indonesia.

Yet before we discuss this common ground in which these multiple identities can find solace, I shall look back on the relations of citizenship, national identity and belonging in order to perhaps understand where this "Fallacy of Singular Affiliation" stems from. Despite the generally accepted notion that citizenship is synonymous with national identity, as I have previously shown, Irving (2007) contends that to understand citizenship as an identity is problematic. To have citizens embrace a single common identity and have them all display similar characteristics would be impossible. In the words of Irving, "to create the conditions for this world would be coercive or manipulative" (2007, p.61). 'Belonging' is neither a viable concept for understanding citizenship, because as Irving (2007) argue, not everyone has a need to belong. In addition to this, a sense of belonging shifts depending on the environment and situation the individual is in (Mitchell \& Parker, 2008). For example, in Mitchell \& Parker's research, when asked about their citizenship some students expressed a stronger relationship to their city than their country. What Irving (2007) proposes as a better alternative to 'belonging' is 'allegiance'. Allegiance encompasses an individual's allegiance to the state, to democratic institutions, to tolerance and liberalism, without having the citizens embrace a single identity, which may result in the Sen's Fallacy of Singular Affiliation. In this research I shall look at a form of citizenship, known as religious citizenship, which manages to integrate religious identity with allegiance to the state, as well as the values needed to participate as citizens of that state (Hudson, 2003; Miedema, 2006; Parker, 2008; Parker \& Hoon, 2013). 


\subsubsection{Religious citizenship}

The discourse of citizenship has evolved and extended into areas beyond the legal and political realm. Citizenship now also encompasses civil, cultural and social areas, hence the emergence of new forms such as 'multi-cultural citizenship' (Baumann, 1999; Parker \& Hoon, 2013). Parker \& Hoon (2013) notes that this form of citizenship was utilised to expand the concept to include "citizenship issues of gender, race, sexuality, ecology, and age" (p.164). With this expanded form of citizenship, marginalised individuals are entitled to full citizenship despite their differences to mainstream society (Parker \& Hoon, 2013) Furthermore Parker and Hoon (2013) argues that it is the engagement of citizens in the socio-cultural-political issues of the state that define an individual's citizenship. Through this understanding, citizenship is no longer merely a given legal status, but includes the individual's participation in public life (Osler \& Starkey, 2005; Weithman, 2002). With respect to this participation in public life, Indonesia's schools not only draw from their secular-citizenship values but also values deriving from religion, to construct their values regarding citizenship overall (see Chapter Two). This means schools instil secure religious identities in their students as well as "building communities of empathetic citizens committed to the common good" (Parker 2008 p.7).

Using Irving's (2007) understanding of identity and allegiance, religious citizenship can be seen as the middle ground in addressing this problem of multiple identities, by encouraging both teachers and students to engage in their religious identity and an allegiance towards the nation. With this, the construction of religious citizenship straddles the two spheres: the secular and the religious. The challenge is to take the positive elements of these two spheres, so that the individual is provided with the means to build an identity as a religious citizen that has allegiance to the state and to democracy, while also demonstrating tolerance (Pohl, 2011). Pohl (2011) further suggests that this is may be done by drawing from either religious references, secular elements or both, as determined by the socio-cultural or the political context. Parker \& Hoon (2013) proposes that religious citizens can employ their religious values that promote inclusivity, peace and tolerance for a 'common good', benefitting both religious and secular citizens. Parker 
\& Hoon (2013, p.167) further believes that, "such pursuit of a "common good" enables members of a common polity to build bridges and enter into dialogue with each other despite their differences in religion, ethnicity or culture." This approach differs from how many nations conduct affairs relating to citizenship and religion, largely endorsing the legitimacy of one uniform, conformist religious group. Taking different religious groups into consideration is far more challenging but is the approach taken in this thesis through inter-religious methods.

This thesis is founded upon a theoretical understanding of citizenship identities as discussed in section 3.2., where citizenship accounts for the feelings about being a citizen as well as status and practice (Osler \& Starkey, 2005). This suggests that the citizenship of individuals is dynamic rather than static. In the wake of 9/11, Mitchell and Parker (2008) argues that citizenship and identity is temporal and flexible, and may shift according to the socio-political conditions of the individuals. As citizenship and identity itself is a form 'knowledge' of how citizens relate to the state (Miller, 2000; Osler \& Starkey, 2005; Weithman, 2002), citizens' understanding is shaped through their own actions and experiences within their socio-cultural settings: it is a form of knowledge that is learnt. This is a social constructivist view based on Dewey (1916), where knowledge is understood as situated, partial and context-bound. Learning and knowledge are constructed through creative actions of individuals who come together in a social environment where they experience, reflect, undergo meaning making, and see that no learning takes place without action (Adams, 2006; Dewey, 1916; Shor, 1992; Sutinen, 2007).

Dewey (1916) explains that experience is crucial to the process of education and that education must be seen as a continual reconstruction of experience. The fluid nature of constructivist learning requires educators to adopt the view that each students will construct knowledge differently and "that these differences stem from the various ways that individuals acquire, select, interpret and organize information" (Adams, 2007, p. 245). The output of teaching values through religious and citizenship education, particularly values regarding religious tolerance, therefore does not solely rest on the curriculum. It is also dependent on how the teachers and students construct their 
understandings of religious tolerance through their own experiences.

In relation to this, when teaching values such as tolerance it must be taken into account that the understanding of values is constructed through the learners' experience of those values in their everyday lives (Hoyt, 2000). Citizenship values, which in the case of this research are values regarding religious inclusivity, are constantly modified through the individual's construction of knowledge. Kaufman (2012) explains:

A constructivist approach holds that moral propositions are right or justified when they are consistent with acceptable moral principles, and moral principles are acceptable when they are the product of an appropriately designed decision procedure. (2011, p. 230)

In addition to the construction of values, identity itself is constructed, so for instance the feeling of exclusion an individual may experience may be the result of a lack of recognition as a citizen: in other words an individual's self-identity maybe overruled by an excluding society (Osler \& Starkey, 2005). As the understanding of one's identity is tied to one's socio-political environment, identity then is always subject to construction and reconstruction. The construction of identities as a social process is reified in discourse and narratives (Hung, Lim, \& Jamaludin, 2010).

Such understandings shape how religious and citizenship education is taught as it can no longer hold to one heterogeneous or normative position on how this should be done when multiple notions are acknowledged. The following conceptual framework describes a way to explore and evaluate the teaching of religious and citizenship education.

\subsection{Conceptual framework for religious education}

In order to understand more clearly the role of religious and citizenship education in Indonesia, we need a conceptual framework by which to evaluate the nature and expression of religious education. In this section I outline a framework for religious education and a framework for inter-religious dialogue that may be used in teaching interreligious relations within religious education. 
There are a number of purposes in having religious education Brelsford (2003), summarizes six different purposes of religious education in the classroom:

...to faithfully form the next generation within the normative identity/beliefs/values of a particular and well-defined religious community; to broadly educate students of varying religious and non-religious identities about the human experience of religion or about a spectrum of historic and contemporary religious traditions; to awaken learners to the spiritual/religious dimensions of their own experience (which might or might not find expression in one or another existing tradition); to inoculate students against unseemly infections of religious fervour; to inculcate a sense of duty and/or morality. (p. 135)

Among these purposes, the first two are the most common reasons for religious education, especially within the context of a diverse society. The difference between these two is the first focuses on maintaining the beliefs and identity within a community, while the second introduces the communities of a society to various religious systems. Zuhdi (2005) asserts that the increasingly pluralistic and secular nature of societies around the world has shifted the purpose of religious education, from merely teaching students of specific religious concepts, to introducing students to various beliefs and cultures in order for them to have a better appreciation of cultures as well. This has occurred particularly since the late 1960's, Jackson (2004) asserts:

...changes in religious, moral and citizenship education from the late 1960s to the end of 1980s can be seen very much against a backdrop of secularization and an increasing religious plurality. However, since 1990s there has been a growing awareness of modern plurality - including more direct experience of various effects of globalization and more awareness of the contested nature of concepts such as religion, ethnicity and culture. ( $p$. 20)

Due to this, scholars have proposed a variety of models for religious co-existence and education; here I will draw on Sterken's (2001) models of religious education in seeing how religious education is defined within the curriculum and I will also draw on Knitter's (2002) models of interreligious dialogue understand how it is implemented by the teachers in the classrooms. Sterkens (2001) proposes three possible models for religious education: mono-religious, multi-religious and inter-religious models. 
1. The mono-religious model sees that the aim of religious education is to learn the religious tradition that is currently held by the students. The superiority of their religion may be implied to students if other religion outside the students' are introduced and although diversity is acknowledged, religions are kept isolated from one another (Bagir, 2008).

2. The multi-religious model aims to teach students of all religions. The main characteristic of this model, is the detachment from any particular religion (Sterkens, 2001). Religion is taught objectively, from a neutral standpoint and learners may not be personally involved in learning religion (Bagir, 2008).

3. The inter-religious model is similar to the multi-religious model but sees the possibility of mutual enrichment as it doesn't view religion as a closed, finished system. Instead, this model expects mutual enrichment, and an openness for contact with others (Bagir, 2008).

Looking at the religious education curriculum in Indonesia, the curriculum applies a mono-religious model where the aim of religious education is the internalisation of a particular religious tradition held by the students - i.e. a Muslim must study Islam, a Catholic must study Catholicism, a Hindu must study Hinduism and so on. However, although these models proposed by Sterken has been found to be useful in evaluating religious education in the curriculum, the model overlooks how individuals themselves (i.e. the teachers and students) conduct religious education when confronted interreligious issues. Knitter (2002) proposes four models of how inter-religious dialogue may occur:

1. The replacement model: Knitter argues that is cannot be truly defined as an approach to inter-faith dialogue because in this model there is no interest in dialogue as this model is exclusivist. Individuals here believe that truth comes only from their religion.

2. The fulfilment model: In this model individuals believe that God's love or beneficence is universal, but that salvation can only be found in one particular religion that has absolute superiority. However, this model as Knitter asserts does 
acknowledge that values and truth can also be found in other religions.

3. The mutuality model: Individuals gathered in this model proposes that there are many true religions and that dialogues between them are crucial. This model assumes that religions are equal in the sense of having the same right to speak and be heard, according to their values. Any claim that one religion is superior to others is rejected.

4. The acceptance model: Knitter's last model assumes that there are many true religions, and that no one religion is superior. This model is different to the mutuality model in that there is no common ground between religions, and therefore it is impossible for one religion to really understand and judge another. This approach encourages religions to preserve, honour and protect the differences between the faiths.

Using Sterken's (2001) model of religious education and Knitter's (2002) model of interreligious dialogue I will identify in Chapter Seven how the teachers and students engage in interreligious issues.

\subsection{Chapter Conclusion}

This chapter has highlighted the many different types, descriptions, models, and methods of citizenship and religious tolerance. I have given a description of the development of citizenship and of religious citizenship. I have also elaborated the theoretical paradigms

of constructivism used in this research and of religious tolerance as a central concept to inter-religious relations, concluding with an outline of religious education and various inter-religious methods. 


\section{CHAPTER 4: METHODOLGY}

\subsection{Chapter introduction}

This chapter describes the methodology undertaken to explore teachers' and students' perceptions of religious education, inclusivity and the construction of their personal identity. As the nature of my research is descriptive I have employed a qualitative methodology to address my research questions.

This chapter will open with an overview of the theoretical paradigm that underpins my methodological approach. I have used social constructivism and constructionism as an appropriate paradigm for my research, which I will explain at the start of this chapter. This is followed by details about the process by which I invited participants to be involved in this research, alongside the rationale behind the data collection methods that I have used. The analysis process will then be explained, as well as an explanation of the integrity and trustworthiness of my research. Ethical considerations will then be provided and this chapter ends with a consideration of the study’s limitations.

\subsection{Research paradigm}

It is argued that the construction of knowledge occurs through everyday experience, reflection and meaning-making (Shor, 1992). Citizenship values, which are the focus of my research, are especially appropriate to explore concepts such as inclusivity as they are constantly modified through an individual's construction of knowledge in their everyday experience. However, the effect of the socio-politicalreligious conditions of Indonesia, such as the various religious backgrounds and different socio-economic conditions of each school (as seen in Chapter One and Two), may result in indifferences in how knowledge is constructed within the context of the social setting (Holstein \& Gubrium, 2008). Therefore, this research takes a social constructivist and constructionist approach. Although the concept of inclusivity, particularly in terms of 
tolerance, has been articulated within Indonesia's national curricula, teachers and students are likely to draw on their own beliefs and experiences to construct their own interpretations of what tolerance is, thus forming their own understandings of religious tolerance. This research will not only explore how teachers and students have constructed their own meanings of tolerance but also how this has contributed to how they have constructed their personal identities and perceptions. This approach necessitates an examination of on how understandings are developed in specific places.

\subsection{Qualitative approach}

In order to investigate what is likely to be complex and 'messy' data, this research was conducted using a qualitative approach, specifically using a single, multi-site case study approach. This methodology allowed me to acquire detailed accounts of one or more cases and also to share the understandings and perceptions of people and how they give meaning to their existence (Berg \& Lune, 2012; Johnson \& Christensen, 2010)

Using a qualitative approach, also allow us to study the world as it naturally occurs without manipulating it, in order to allow for multiple perspectives, thus showing that the world can be viewed and understood in diverse ways (N.I.U., n.d). A case study research method was used to explore the complex nature of things that go on within a bounded system. This allowed an in-depth understanding of the cases in the bounded system through multiple sources of data collection will be possible (Creswell, 2012). A multi-site case study was specifically used to investigate the teachers' and students' perceptions and enabled a comparative study between the schools.

\subsection{Selecting case study schools}

This research used purposive critical-case sampling by selecting three schools in Indonesia that were reported to have different underlying philosophy in relation to values education. Johnson \& Christensen (2012) defines purposive critical-case sampling as a form of purposive sampling in which the participants are selected based on what are 
believed to be particularly important cases. The purpose of the study is to have a comparison that focuses on teachers' and students' perceptions within each of the three types of schools, without analysing or evaluating the quality of education. Thus the criteria of choice when selecting the schools are ones that have similar levels of school certification. Schools in Indonesia are certified and ranked (A, B, or C) by the government as an assessment of quality; by examining the grade of the schools (A, B or C), it was possible to make compatible selections. All invited schools had an 'A' grade.

Schools were invited to participate through a letter of invitation sent to the principal outlining the purpose of the research (Appendices A and B). All of the schools initially agreed to participate. The public school also requested a letter of approval of research from the local government body. This was a reasonable request as public schools are subject to government policies. Consent forms were completed by the Principals who consented for their schools to take part in the research and provided a contact person to liaise with regarding potential participant teachers and students.

This liaison person then helped me to identify participants to invite who were teachers of religious education and citizenship education. I focused on both of these types of teachers as religious education teachers and citizenship education teachers perform separate roles and schools will have at least one for each subject in each school.

\subsubsection{Description of case study schools}

The three participating schools were all secondary schools, two of which were state-sponsored, and one private school. All of the schools implemented the national curriculum but were distinct from one another in terms of educational ideology (see Table 3.1). Schools have been allocated pseudonyms in keeping with the ethical requirements of this study. 


\begin{tabular}{|l|l|l|l|}
\hline SCHOOL & $\begin{array}{l}\text { JAKARTA } \\
\text { MADRASAH } \\
\text { HIGH }\end{array}$ & $\begin{array}{l}\text { JAKARTA } \\
\text { NATIONAL } \\
\text { HIGH }\end{array}$ & $\begin{array}{l}\text { JAKARTA } \\
\text { PUBLIC HIGH }\end{array}$ \\
\hline Accreditation & A & A & A \\
\hline Roll & 487 & 385 & 1189 \\
\hline Authority & State & Private & State \\
\hline Founded & 1992 & 1929 & 1958 \\
\hline Curriculum & $\begin{array}{l}\text { National } \\
\text { curriculum } \\
\text { additional curricula } \\
\text { on Islamic studies }\end{array}$ & $\begin{array}{l}\text { National } \\
\text { curriculum }\end{array}$ & National curriculum \\
\hline
\end{tabular}

Table 4.1 Profile comparison of case study schools

The first selected school is an Islamic school, more commonly known as a Madrasah, which although it used the national curriculum, it also has an additional Islamic curriculum in order to provide a much deeper level of religious education. The Jakarta Madrasah High extends the national curriculum by having additional curricula that focuses on Islamic-based subjects such as Islamic jurisprudence, Arabic language, Islamic culture, and so on. The second school, Jakarta Public High, was a state run public high school that solely utilises the national curriculum. Last is a privately run high school, Jakarta National High. The school used the national curriculum, but in keeping with the nationalistic ideology of their founder Indonesia's state ideology, the Pancasila, is also emphasised. I will elaborate on each of these schools in greater detail below.

\subsubsection{Jakarta Madrasah High}

As explained in Chapter Two, there are three types of formal Islamic schools in Indonesia: the pesantren (religious and traditional boarding school), the Madrasah (religious day school) and the sekolah Islam (a day school that fuses secular curriculum and religious teachings) (Zuhdi, 2006). Madrasahs constitute $17.06 \%$ of the total schooling in Indonesia (Kemenag, 2009).

The Madrasah is under the supervision of the Ministry of Religious Affairs 
(MORA), in collaboration with the Ministry of Education and Culture (MOEC) for the curriculum. With this supervision, the government has directly influenced the evolution of the Indonesian Islamic schools. In light of the changing dynamics of Indonesian society, such as a notable resurgence of Islamic identity and examples of recent inter- and intra-religious tensions, there has been a growing need for more open-minded, inclusive schools (Bagir, 2008; Hefner, 2013; Pohl, 2011; Zuhdi, 2006). As Pohl (2011), Hefner (2013) and Bagir (2008) suggest, there has been a rise in the need for an Islamic education model that addresses issues of religious diversity, co-citizenship, tolerance and mutual understanding. Some schools, including Madrasahs, have employed a more progressive, critical inquiry approach towards addressing these issues (Parker, 2008). However, it is still uncommon for the majority of schools to employ such a method, as most of them still rely on the conventional, rote memorisation of learning pluralistic citizenship values.

Much like a secular school, a Madrasah can be either public or private. The Jakarta Madrasah High is a public Islamic day school that was founded in 1992. The school aims to provide a balance of religious subjects (that is Islamic) and secular subjects. It has achieved an accreditation of 'A' from the government to signify its excellence in providing such an education. The school comprises students of middle to lower income families (field notes, 2013). Nevertheless, since the school is a statesponsored public school in one of the richest provinces in Indonesia, the Jakarta Madrasah High has adequate facilities and resources when compared to the Jakarta National High (field notes, 2013).

As an Islamic day school, all of the students are Muslims. To make sure of this, in order to attend the school the students are given a competency test in various subjects including Islamic Education. They are tested on not only their general knowledge of Islam but also the ability to recite the Qur'an (Islam's Holy book) in Arabic, and also the ability to perform the shalat or the Islamic prayer.

Madrasahs have an additional curriculum tailored specifically for their Islamic teachings. This additional curriculum is but an expansion of the Islamic religious education already within the national curriculum. This includes subjects on:

1. Al-Qur'an and Hadith (sayings of the prophet Muhammad) 
2. Aqidah (faith, i.e. definitions of Islam, what is a Muslim) and Akhlaq (morality)

3. Fiqih (Islamic jurisprudence)

4. History of Islamic Culture

5. Arabic Language (Kemenag, 2008)

All of these subjects (especially the first three), along with citizenship education play a critical role not only in how the teachers and students perceive tolerance but also in how they form their perceptions of identity and civic values (Chapter Five and Six).

\subsubsection{Jakarta Public High}

The Jakarta Public High was established in 1958. It is known as one of the finest schools, not only in Jakarta, but in Indonesia. It was one of the first schools to be distinguished by the Ministry of Education and Culture as a Rintisan Sekolah Bertaraf Internasional (RSBI) or a pioneering international school, in 2006 before the constitutional court dissolved the RSBI in 2013 for fostering discrimination (Republika, 2013). However, the dissolution of the RSBI does not appear to have impeded the schools' intent to retain its 'international standard'. One notable illustration of this was the use of the English language for the motivational quotes plaque and posters hung from ceilings or on walls throughout the school (field notes, 2013)

Similar to the Jakarta National High, the school follows the national curriculum in conducting its schooling and it is accredited 'A' by the government. One major difference is that the school is one of the designated 'Excellent Schools' in the province of Jakarta (field notes, 2013). With its notably high quality, the school has attracted students from middle-upper class families, with only a small percentage coming from lower income families receiving scholarships from the school (field notes, 2013). The school is a public non-faith based school - however, with the increasing pressure of Indonesia's growing Islamic-identified population, the school has built a mosque in its grounds.

\subsubsection{Jakarta National High}

A private school founded in 1929, the Jakarta National School is a branch of the 
National School Foundation, which was established in Yogyakarta in 1922. The National School Foundation provides all levels of schooling: kindergarten, elementary, junior high school, high school and tertiary education. National Schools in Indonesia has had a long history of assisting Indonesia's independence efforts. At the beginning of the Second World War, National Schools had a total of 199 branches, 207 schools, 650 teachers, and about 20,000 students (Hing, 1978). The schools were established in response to colonialist suppression during the Indonesian pre-independence era, and emphasised education as a means to unite the culturally and ideologically diverse segments of population in Indonesia (Hing, 1978).

Due to its anti-colonial foundations and pre-independence influences, the school is deeply committed to a nationalistic agenda and maintaining and constructing national identity. It seeks to achieve this through active participation in the schools. Examples of this can be seen in the weekly flag-raising ceremony conducted every Monday morning, the 'citizenship retreats' organised by the school, and working with the military. By these means students are 're-educated' on what it means to be Indonesian (field notes, 2013).

At its conception, the school attracted the support of many pro-independence organisations that were working towards nationalist objectives such as national unity, independence and the rejection of prevalent Dutch influences. As a result the National Schools became a breeding ground for anti-colonial attitudes, which were encouraged and fostered among its teachers and students (Hing, 1978).

When Indonesia gained independence in 1945, the National Schools were unable to recreate a new and meaningful role for themselves in Indonesia's post-independence environment. The rapid expansion of government schools and the infusion of nationalist values into the general education system amplified and hastened the demise of the National Schools, as they were no longer the sole educational provider for educating young Indonesians in nationalist values (Hing, 1978). Government sponsored schools and other private schools become as qualified and sometimes exceedingly more qualified than the National Schools in providing education. Adding to this, National Schools were adamant in maintaining their autonomous values, such as refusing to seek assistance from 
the government, which they argued would compromise their principles (Hing, 1978)

The current state of the Jakarta National School is often underfunded, resulting in meagre school facilities and resources, and underpaid teachers (field notes, 2013). Furthermore, unlike state-sponsored schools, as it is a private school the Jakarta National High receives its funding by selling school application forms for students wishing to attend, and charging minimal fees for students currently attending. Understanding the severity of its financial situation, the Jakarta National School does receive government funding, but this is inadequate to cope with the high costs of running the school (field notes, 2013).

The lack of funding has resulted in a lack of modern school resources, thus the school only attracts students from middle-lower to lower income families (field notes, 2013). The Jakarta National High's visible school resources are of a quality lower than of the two other schools examined in this study. Surprisingly, according to the 2006 government accreditation body the school has achieved the grade 'A', the highest grade possible to achieve. This grade indicates that the school is of the best quality, based on the government standards and students attending the school may receive a good quality education. With no longer being at the forefront of the struggle against colonialism, the Jakarta National High has also tempered its idealised nationalistic aspirations. Pressured by the governments' standardised curriculum and the limited teaching time due to the yearly national exams, teachers have often had to reduce emphasis on the school's nationalistic ideals (field notes, 2013). Teachers are forced to provide subjects in a transmission-oriented manner, often strictly based on the government's curriculum.

Being a non-religious school, students from any religious background are accepted. The religious background of the majority of the students is Islamic, with a small minority consisting of Catholics, Protestants, and Buddhists. Although there has been a growing religiosity within the school, the National High is still anchored by its nationalistic ideals. It emphasises Indonesia's national motto, Bhinneka Tunggal Ika (Unity in Diversity) as the foundation for dealing with issues of inclusivity, including religious diversity (field notes, 2013). 


\subsubsection{Description of participants from each school}

Two religious education teachers and two citizenship education teachers participated from the Madrasah. One religious education teacher and one citizenship education teacher participated from the Jakarta National High school. Lastly, one religious education teacher and one citizenship education teacher participated from the Jakarta Public High school (see Table 4.2). The higher number of teacher participants in the Madrasah was due to the high interest of teachers who wanted to participate in the research. Thus, as a result of this enthusiasm, the researcher opted to include the additional teacher participants in this school.

\begin{tabular}{|l|l|l|l|}
\hline $\begin{array}{l}\text { SCHOOL } \\
\text { PARTICIPANTS }\end{array}$ & $\begin{array}{l}\text { JAKARTA } \\
\text { MADRASAH } \\
\text { HIGH }\end{array}$ & $\begin{array}{l}\text { JAKARTA } \\
\text { NATIONAL } \\
\text { HIGH }\end{array}$ & $\begin{array}{l}\text { JAKARTA } \\
\text { PUBLIC } \\
\text { HIGH }\end{array}$ \\
\hline $\begin{array}{l}\text { Total Number of } \\
\text { Teacher Participants }\end{array}$ & 4 & 2 & 2 \\
\hline Citizenship & 2 & 1 & 1 \\
\hline Religion & 2 & 1 & 1 \\
\hline Male & 4 & 2 & 1 \\
\hline Female & 0 & 0 & 1 \\
\hline Total Number of Student & 7 & 6 & 7 \\
\hline Participants & & 5 & 2 \\
\hline Male & 2 & 5 & 5 \\
\hline Female & 5 & 2 & \\
\hline
\end{tabular}

Table 4.2 Summary of participants from each school

Potential participants were given information letters and consent forms which outlined the research and which contained example questions that were used in the individual teacher interviews (Appendices $\mathrm{C}$ and $\mathrm{D}$ ). Teachers were given the opportunity to ask 
questions regarding the research prior to deciding whether to sign the consent forms. This was done so that no teachers felt coerced into the research. An information card listing the teacher's name, pseudonym, religion, years of teaching and teaching subject, was also provided in order to record the teachers' personal data (Appendix G).

Teachers who consented then helped invite students willing to participate in the research. Students that were asked to participate were limited to a minimum age of 16, in order to receive consent solely from the students without additional parental consent needed, as per Victoria University of Wellington's research ethics. Similar to the teacher participants, students were given information letters about the research, and example questions that would be used in focus group interviews. Also, students were given time prior to the research to ask any necessary questions, so they could consider their participation in the research thoroughly. Initially seven students agreed to participate in the research at the Madrasah, but two opted out after the focus group interviews, returning to class due to having a test and therefore they did not participate in the secret box activity. Seven students took part from the public school and six participated from the private school (see Table 3.2). Research in the case of the private school initially proved problematic, as some students did not wish to participate after reading the information letter and consent forms. Yet with the help of the teachers, I was able to find enough students freely willing participate. Similar to the teachers, students were also given information letters and consent forms prior to the focus group interviews (Appendices $\mathrm{E}$ and F) Information cards were also given to be filled out, in order to provide the students' personal data (Appendix G). Participating students, aside from those from the Madrasah, represented diverse religious backgrounds and thus provided a wider range of personal insight on the issues inquired about.

One situation that I found interesting was the importance of my personal religion. Prior to the interviews almost all of the participants asked me further questions about the university which I was doing my research at, and my religion. During my research at the Madrasah, a security guard that guided me to the headmasters' office during my period of requesting permission to conduct the research, inquired about my religion and was puzzled to find that a non-Muslim wanted to conduct research in a Muslim school. It is merely a common custom to ask of someone's religion, but this showed just how 
significant my personal religious views were to the process of research. I reflect on this further in the final section of this chapter.

\subsection{Data collection methods}

The data collection methods used in the research include semi-structured interviews, focus groups and analysis of documents. As every method gives a different outcome, by combining different methods "researchers are able to obtain a better, more substantive picture of reality; a richer, more complete array of symbols and theoretical concepts; and a means of verifying many of these elements" (Berg \& Lune, 2012. p.6). This use of multiple methods is known as triangulation. By collecting data in multiple forms I was able to obtain a more complete understanding of the perceptions of both the teachers and students of religion, citizenship and identity.

\subsubsection{Semi-structured Interviews}

Individual semi-structured interviews were conducted to collect data from the religious education and citizenship education teachers of the chosen schools. As Johnson \& Christensen (2012) point out, interviews are used to obtain information on the interviewee's "thoughts, beliefs, knowledge, reasoning, motivations and feelings about a topic." (p.202) They allow the researcher to gain an understanding of that person's perspective. A semi-structured interview allows flexibility for additional questions and impromptu issues that arise at the time of the interview (Berg \& Lune, 2012). Individual interviews were conducted with the teachers, as there were only a small number of teacher participants, and topics of religious tolerance and personal identities would potentially need to be recorded in confidence. A digital recorder was used to document the all of the interview sessions, which I later transcribed myself (See appendix $\mathrm{H}$ for interview questions).

\subsubsection{Focus Groups}

A focus group is a type of group interview in which discussion is led by a moderator to examine the group's thoughts, beliefs, or feelings on a particular topic 
(Johnson \& Christensen, 2010). They reveal "conscious, semiconscious, and unconscious psychological and sociocultural characteristics and processes among various groups" (Berg \& Lune, 2012, p. 144). As students may view individual interviews apprehensively, focus group interviews were used with students in each of the three schools (See appendix $\mathrm{H}$ for interview questions).

As suggested by Berg \& Lune (2012), this method is an effective technique for drawing out the participants' perceptions, which in this case are the perceptions of the students regarding tolerance and their personal identity. The group dynamic is made use of in order to gather data regarding topics of interest to the group that the researcher can see might provide perspectives and viewpoints. Berg \& Lune (2012) suggest that the ideal number of participants for a focus group interview is six to eight. Groups in this study ranged from six to seven in size. This group size aided in effectively eliciting response from the students in all the focus group interviews. Immediately before commencing the focus group sessions, two mind-mapping activities were conducted in order to help stimulate discussion prior to the interviews. The mind map used a Strengths, Weaknesses, Opportunities and Threats (SWOT) analysis on religious tolerance and students' sense of identity. The SWOT analysis also provided insights about the students at each school, and allowed some of the quieter students to participate equally, as focus group interviews are often dominated by outspoken members (Berg \& Lune, 2012).

The process of the focus group interviews slightly differed between schools. All of the participants from each school initially showed hesitation prior to the interviews as the mind-mapping activities initially proved difficult for them. Some students suggested that this was due to their concerns about the topic of discussion (field notes, 2013). Yet, given time, students from the Madrasah and the Jakarta Public High were able complete the activities, although students from the Jakarta National High were unable to do so and opted to proceed to the focus-group interview.

During the focus group interviews, students from the Madrasah showed enthusiasm and curiosity towards the research, often inquiring further about the topics being asked. A similar occurrence took place while interviewing students at the Jakarta Public High: many displayed deep interest in the research topic. Students from the Jakarta National High, however, showed a lack of response to or interest in the topics being 
addressed, giving minimal and short answers. This may have been due to the different social and economic conditions of each school, as students from Jakarta National High had lower educational socio-economic status compared to the other two schools and lower levels of literacy as well.

\subsubsection{Secret Box Activity}

One significant challenge in this research was to find ways to address the sensitive nature of religious issues and how to encourage young people to discuss these. The secret box activity is a strategy that asks the student participants to anonymously write down thoughts or ideas that they were unwilling to discuss in the focus group interviews and post their responses into a box when done (Punch, 2002). As focus group interviews with young people are flawed for a number reasons, such as dominance from the outspoken members (as explained above), or the sensitive nature of the topic being discussed, there was the potential that some might feel it was unsuitable to discuss some matters openly. The secret box strategy was used immediately following the focus group interviews as a way to allow students to raise other issues or describe 'hot' topics. All of the students who participated in the focus group interviews participated in the secret box activity. Most students either reiterated or expanded on the points they made in the interviews, while some discussed more of their personal experiences regarding tolerance and personal identity. This provided data that otherwise would be hard to obtain through methods such as the focus groups, as the secret box method provides anonymity and thus freedom to communicate opinions on sensitive or personal issues.

\subsubsection{Secondary Data}

As explained by Johnson \& Christensen (2010), secondary data may include personal documents, official documents, physical data and archived research data. The collection of secondary data was done in order to achieve a more detailed picture of the perceptions and practices of the teachers and/or students of each school. Secondary data was collected from various sources including official documents, websites, lesson plans and teaching guidelines. I used these to provide supporting information on how teachers 
perceive the topic being taught and to see if data such as official curriculum documents aligns with the perceptions of the teachers.

\subsection{Data analysis methods}

Johnson and Christensen (2010) propose that the processes of data collection and data analysis occur simultaneously. With this understanding, I condensed the data while still collecting data from other schools. According to Creswell (2012) there are three main steps in data analysis of qualitative research:

1. preparing and organising data;

2. condensing data into themes;

3. representing data.

After collecting then preparing and organising the data that I had obtained, I then began to condense it into appropriate themes. As the first step of analysis is to build a manageable coding scheme or classification (Patton, 2002). This is done in order to minimise any chaos or confusion with the amount of data that has been gathered. After identifying themes and grouping the data under initial subcategories, I then transcribed the interview data verbatim. Along with the written notes acquired from the secret box activity, I then translated the data from Indonesian into English. Esposito (2001) suggests there are two major tasks in translating data: the first is to translate the questions into a form that is easily understood by the participant, in this situation, the translation of questions from English to Indonesian. The second is to translate the participant's communicated responses with as deep a meaning as possible, as it is held that both quantitative and qualitative researchers are faced with the challenge of producing meaning-based translations rather than word-for-word translations (Esposito, 2001). As not all concepts are universally translatable (Jones \& Kay, 1992). I have personally translated the data that I acquired from the interviews and secret box activities, which were translated into the closest possible meanings as intended by the participant. I faced no difficulties during the translation process.

Barbour (2008) warns of the importance of avoiding pre-determining coding categories prior to data collection and analysis. This may lead to overt reliance on 
preconceived themes, biases and interview questions, rather than allowing for any flexibility when collecting the data. Once several codes were identified, I categorised the focus group and interview data in order to establish and make sense of possible patterns. This was done through convergence (Guba \& Lincoln, 2001), or making sense of the data that fits together. Barbour describes how some people like to go from very detailed codes, which they then group into broader themes, whereas others prefer to conceptualise in broad themes followed by separation into narrower codes - I have employed the former (Barbour, 2008). I began by looking for recurring regularities in the data which could then be sorted into categories (Patton, 2002). During categorisations, I realized that various subcategories crossed multiple themes. Barbour (2008) views this merely as a reflection of the complexity and inclusivity of qualitative research. This also may aid in understanding how shared perceptions and identities are formed.

After this stage, I then re-analysed the data and the classification system to verify the meaningfulness and accuracy of the categories, and the placement of the data within them. This was done to guard against any generalising of the opinions expressed in the focus group, as well as oversimplifying of complex discussions (Barbour, 2008). Data from the secret box activity and secondary data was then incorporated to further explore the perceptions of teachers and students. Throughout the data analysis, I continued to connect with the literature surrounding the topic to enhance the validity of the data. As advised by Burton, Brundrett, and Jones (2008), I have presented my data with my analysis and also used the research questions as a framework in conducting the analysis. Creswell (2012) suggests that in when dealing with multiple interview subjects and forms of data collection, it is common to give a detailed description and identify themes in each. (this is called within-case analysis). and then follow with a cross-case analysis of themes across the cases including their interpretations of meanings. Chapters Four and Five contain both within-case analyses of each school and cross-case analyses between schools. 


\subsection{Trustworthiness and Integrity}

Researcher bias is a major threat to validity due to selective observation, selective recording, and the influence of personal perspectives on data interpretation (Johnson \& Christensen, 2010). As a part of a religious minority in Indonesia, I am aware of the possible biases that I may have, which could lead to interpreting what the participants had to say wrongly, or the possibility of forming leading questions. Inevitably, my presence as a non-Muslim influenced the responses participants gave. To minimise this, I continually emphasised the participants own perceptions of the issues being discussed. Hopefully this self-reflexivity has minimised biases I might have which might have affected the research process. This self-reflexivity can be seen during the interviews. Before proceeding with the questions I had planned, I reflected on my own stance and possible biases regarding the issue participants were being asked about, in particular those issues concerning persecutions of non-Muslims and the closure of Churches throughout Indonesia.

Interpretive validity was maintained by using direct quotations. It was also maximised through discussion of the interpretations and conclusions with peers, at a presentation, and with my supervisor, to address any problems that were identified. Internal validity was maximised by using data triangulations as described by Berg and Lune (2012). The data was collected through several methods leading to a better understanding of the perceptions of teachers and students of religion, tolerance and personal identity. The data collected required translation of the questions posed and the answers that were given. As advised by Esposito (2011), during the data collection process the researcher, being fluent in both English and Indonesian, processed the meaning of the participants' answers. Rather than conducting a word-by-word translation, through this method it was possible to adjust questions and comments in response to unanticipated answers. Through the translation of the meanings accurate information can be produced, and, the dynamic flexibility of the data collection process is not inhibited (Esposito, 2001).

External validity was increased by using multiple case studies, which may lead to replication logic. This refers to the increased confidence that can be had in research 
findings that are compared across multiple settings. As stated by Johnson and Christensen (2012), the term 'integrity' refers to how dependable the findings are. Through the use of multiple case studies, direct interviews, participant feedback and detailed descriptions of the methods being used, the findings of this research will be both consistent and reliable.

\subsection{Ethical Considerations}

An application for ethical approval was submitted to the Faculty of Education Ethics Committee and approved by the Victoria University of Wellington Faculty of Education Ethics Committee (no.19857). The investigation observed the ethical guidelines of the New Zealand Association for Research in Education (NZARE).

As explained previously, informed consent was obtained from each of the participants. The consent form was accompanied by a cover letter describing the purpose of the research (Appendices A and B). Teacher participants will be given a copy of the thesis as a form of appreciation. The identity of participants has been protected throughout the study and all participants have been given pseudonyms. Schools have also been given pseudonyms in the thesis. Each school will be offered a copy of the completed thesis and will be advised that the thesis will be stored in the Victoria University Library.

\subsection{Limitations of study}

Due to the time constraints and limitations of a one-year Master's research thesis the study conducted here was small scale explorative study which cannot provide generalised findings. Yet, though this is a small study it may be useful for future study, as it could be used to establish frameworks for similar research or to build a larger project.

A limiting factor of the research was the time constraint of the interviews. Some interviews might have been longer if it were not due to the limited availability of the participants. At one school, two students were unable to conduct the secret box activity due to time constraints. This is a common feature of research in schools, and care must be taken to respect the conditions by which research is permitted within schools. In the 
following chapter I shall look at the findings of the research particularly in regards to the perceptions of the teachers' and students' towards citizenship, religion and identity. 


\section{CHAPTER 5: SECONDARY SCHOOL TEACHERS'AND STUDENTS PERCEPTIONS TOWARDS CITIZENSHIP, RELIGION AND IDENTITY}

\subsection{Chapter introduction}

The focus of this chapter is the perceptions of teachers and students regarding citizenship, religion and identity, addressing my first research question. This chapter reports on data generated through the teachers' and students' group activity, focus group interviews, the secret box technique and field notes.

The chapter begins by exploring how the participants across the three schools defined their own identity. Section 5.2 then examines the role of religion as perceived by teachers and students from each school, and how it has shaped their moral values. Section 5.3 looks at the relationship of religion, citizenship and identity as perceived by the teachers and students. This chapter concludes by stating that religion had become a pivotal factor in defining the teachers' and students' understanding of citizenship and identity.

\subsection{The role of religion}

This section examines how the role of religion was perceived by participants. The purpose of this section is to highlight how religion has played a role not only in shaping their identities, but also their values. The process of attempting to instil religious identity in students took a number of different forms in the three case study schools. This occurred through direct forms of religious teaching and learning (religious education), but also indirect forms - such as the values, character and material aspects of affirmation of a particular way of doing things. In this section I begin by examining how this was practiced in each of the three schools. This is followed by an examination of participants' perceptions of the relationship between religion and citizenship. 


\subsubsection{Schools and religion}

\section{Jakarta Madrasah High:}

As an Islamic religious school, one of Madrasah school's main tenets is a focus on religion. This is done while also attempting to balance and integrate general and religious studies (Pohl, 2011; Zuhdi, 2006). This includes the additional curriculum on Islamic knowledge (as described in Chapter Two), as well as the teaching of specific values which are intertwined with citizenship education. The findings of this research showed that this has affected not only how the teachers and students negotiate their identity, but also their moral values and attitudes towards religious tolerance in particular, which I will analyse in the following chapter. The school itself has attempted to emphasise maintain its Islamic identity through various methods on top of the in-class teaching.

During my observations of the school I noticed how intensely it promoted its Islamic values. For example, the colour green was often used as a theme in the school facilities - all of the school walls were painted green. When I inquired about this, I was told green is the traditional colour of Islam (field notes, 2013). In addition to this, pictures of Indonesian Islamic figures who were revered as national heroes were posted on the walls within the classrooms. The colour green was also used in the school's official logo and the students' physical education uniform. Posters of verses citing the Qur'an filled the hallways and stairways. Female teachers were required to wear the hijab, as were the female students. Unlike other schools, male students were required to wear a long sleeve shirt as their uniform. Staff and students of the school consisted solely of individuals with an Islamic background. Students who attended the high school were from lower-middle class families, some with prior education in a public school, a Madrasah, or a pesantren.

The school itself did not have a policy on gender segregation and my own observations revealed no segregation between the male and female students in their socialising. However, same-sex socialising was not promoted by the students themselves. An example of this was seen during the group activities prior to the focus group interviews, where two male students were more comfortable being in a group with their male counterparts, and were even told by the female students "girls are supposed to be 
with girls, and guys with guys" (field notes, 2013). This occurred even though initially the male students were sitting far from each other and did not appear to be close friends. Parker \& Nilan (2013) note that due to the influence of parents and school, students' behaviour in socialising "revolves around balancing fun and propriety" (p.131).

\section{Jakarta Public High:}

The Jakarta Public High, as explained in Chapter Two, is a public, non-sectarian school that uses the national curriculum. The school is known as one the best schools in Jakarta and attracts upper class, educated families. It is considered an elite public school where some of the most talented students go, and many students living far from the area apply to attend (field notes, 2013). Being a public school, both staff and students represent various religious backgrounds. Nevertheless, similar to Jakarta National High, the school has shown that it tries to cater to the growing religiosity of its students, especially Muslims as they are the majority of the population. For example, the school has constructed a mosque within the school grounds, much like the Jakarta National High. However, it tries to remain true to its non-sectarian, pluralistic, nationalist origins, as we can see in the teachers' perceptions of the role of religion in section 5.3.2.

\section{Jakarta National High:}

With the growing Islamic conservatism in recent years (see Chapter Two), the Jakarta National High has been under pressure to deal with this issue. Having been known traditionally as a nationalist-secular school, the school has tried to cater for the growing religiosity of Indonesians, particularly Muslims who make up the majority of the

student population, by constructing a small mosque on school grounds (field notes, 2013). This has raised issues for both Muslims and non-Muslims wishing to have their children attend a more secular school, as Ucok (M, Protestant, citizenship education teacher) explains:

Once there was a parent coming to get the school application form for her child. Seeing the new musholla (small mosque) being built on school grounds she asked, "I want to ask sir, is National High a religious school?" which I then replied, "no it's not, this is a national ideology based school." "Oh why then there is musholla up front?" "Oh yes, 
that's only for a place for worship but it doesn't mean that this is a religious school. All religions are taught." Her child went on to apply and eventually attended this school. (Ucok, M, Protestan, citizenship education teacher)

Yet despite Ucok's attempt to minimise the significance of this mosque, a poster situated near the building warns of the coming apocalypse and warns the non-believers (i.e. non-Muslims and non-Sunni Muslims) of hell (field notes, 2013) Ucok (M, Protestant), also expressed his concerns over the increasing amount of religiosity among the Muslim teachers at this school following the formal interview session (field notes, 2013). This was evident from the prevalent wearing of hijab (Islamic headdress) by the female Muslim teachers. Yet it must be noted that this in itself had not been an issue for any other teachers I interviewed (field notes, 2013). Students in Jakarta National High seemed to be more relaxed about mixed-sex socialising and mixed-religion socialising, and none showed discomfort during the mixed sex group activities. In the face of the growing religiosity seen within the school itself, Jakarta National High, as previously explained in Chapter Two, tried to emphasise nationalistic education, although the school does not have an additional curriculum like the Jakarta Madrasah High to support its aspirations in doing so. It does, however, provide a more nationalistic education through the school culture which it tries to assert and emphasise through its teaching and its staff (Hing, 1978).

\subsubsection{Religion and the construction of the moral self}

One of the aims of national education is to develop faith and piety towards one almighty God, and good morality in each student (Kemendikbud, 2003). Studies by Zuhdi (2006) have shown how the national curriculum has attempted, and to a great extent succeeded, in implementing religion as a compulsory subject. Dr. Mukti Ali a former Indonesian Religious Affairs minister, asserts that religion in Indonesia has made a positive contribution to social and economic development (Ali, 1974). Religion therefore cannot be separated from development, as "it is a quest for the wholeness of life. To say that religion has no relation to development is to deny the actual base from which its value and premises are derived" (Ali, 1974, pg.143). Parker \& Nilan (2013) argue that young people's concerns about religion are more about their own identity as 
moral and devout individuals. They also argue that adolescents are constantly asking themselves moral questions in regard to their religion, such as questioning "Is this what a good Muslim would do?" They further argue that although this might sound like individualisation, it is however a commitment in a strengthened community to live life according to their religious values (Parker \& Nilan, 2013).

When asked about their religion and morality, findings revealed that a majority of participants from across the three schools felt a strong connection between religion and morality. Teachers from Jakarta Madrasah High indicated the importance of learning religion in connection to morality. Budi (M, Muslim) a citizenship education teacher, asserts that "It is important because religion is a fundamental need. It is a point of reference in acting." Fredy (M, Muslim), also a citizenship education teacher, reiterates this point: "Religion? It is a tool to form a student's character. Religion is related to the personal character of the student that sees ahead, so every action they do, they will think about the consequences. Will it be alright or will it be bad.” Budi (M, Muslim, citizenship education teacher) further maintains the connection between morality and religion: "citizenship education was once called PMP (Pancasila Moral Education)... this is morality and morality cannot be detached from religion. I want it to go that way." Similarly, Arman (M, Muslim) a religious education teacher, expands on the relationship between religion and morality: "in Islamic religious knowledge there are many teachings that turn a person into a better person, and the slogans from the Qur'an apply to how to live one's life with more passion and benefit to others."

In Jakarta Public High, teachers share similar views on the necessity of religion in constructing morality. Ibnu (M, Muslim) an Islamic religious education teacher elaborated on this:

Honestly, all religions, whether it be Islam, Christianity, Buddhism, etc. at their essence teach universal ethics. This means moral problems, ethical problems that are acknowledged as universal, their solutions are within all religions. Islam forbids murder, Christianity as well, and also other religions. Matters that are universal in nature end in religion, this means it cannot be from laws or born outside of religion. Basically every religion is needed as a point of reference. (Ibnu, M, Muslim, Islamic religious education teacher) 
Rani (F, Muslim) a citizenship education teacher from Jakarta Public High, explains how her relationship with religion helps construct and maintain her daily moral values:

Personally I see religion as a brake. So for social things we learn about tolerance, ok, but sometimes when we go to religion it is about our relationship with God that is spiritual and intimate. So when we do disgraceful things, we remember our religion. When we remember God then we'll say to ourselves, 'oh we shouldn't do that'. That becomes our defence, our brake in not doing good things. (Rani, F, Muslim, citizenship education teacher)

Rani's view of religion as maintaining a relationship with God and following God's will has helped Rani construct and maintain her moral values. This importance of piety towards God can also be seen in the curriculum as it is one of the main aims of Indonesia's education system (Kemendikbud, 2003)

Mirroring teachers from Jakarta Public High and Jakarta Madrasah High, Sukono (M, Protestant) a Christian religious education teacher from Jakarta National High, explains his view on the purpose of religion and its relationship with moral values:

Faith is not merely a matter of morality, but it is about having certainty in life. Because we are not living just for now but also the life after this. So religion is just not for living a moral life, that is why it needs to be taught. (Sukono, M, Protestant, Christian education teacher)

Parker \& Nilan (2013), as explained above, argued that young people have built a strong bond between religion and the construction of their morality. The findings presented from teachers in Jakarta Madrasah High and Jakarta Public High confirm this and show how religion has become a critical foundation in the construction of morality not only for young people but also adults as well.

Most teachers across the three schools had positive views on the correlation between religion and morality. However, not all teacher participants strongly held the belief that religion is necessary in learning moral values. A notable exception was a teacher from the Jakarta National High, Ucok (M, Protestant) who explains his views on the relationship of religion with moral values thusly:

For someone to have morals they don't have to adhere to a religion. What if that person follows the law? This can be done through laws, because if someone follows the laws then he or she has morals. I think people can have morals without having a religion, as long as they obey the laws and the rules, they have morals. They don't break the laws, they don't 
violate norms, I think they can have morals. (Ucok, M, Protestant, citizenship education teacher)

As religion has not only become a personal need but also a societal need, Ucok's views can be considered a minority opposition to those of his peers as well as his students. Following the formal interview, Ucok explained how he thinks Indonesia should go back to its nationalistic roots rather than progressing towards more religious values (field notes, 2013).

Similar to the teacher participants, a majority of the student participants expressed views on the necessity of religion in constructing and maintaining one's morality. Three student participants from Jakarta Madrasah High reported similar answers to the students above. As Fitri (F, Muslim, 16yrs) from Jakarta Madrasah High states, "I think studying religion is important because within religion there is knowledge about our daily lives". Tina (F, Muslim 16yrs) from the Jakarta Madrasah High describes her view of how religion is important for the self: "it's important so that we can gain knowledge on the religion we believe in, not only for schools but also ourselves. Our morality". Gege (F, Muslim, 18yrs), also a student from Jakarta Madrasah High, agrees on this and explains how religion can be used as a moral guide:

Maybe for Islam, we see that religion is a guide in our lives, we use the Qur'an and the Hadith. In our everyday lives maybe morals are values from such as the things we learn in sociology. Moral values in society are cultural values but still, the first is from religion. (Gege, F, Muslim, 18yrs)

Using the secret box method following the focus group interview provided further insight on the relationship between religion and morality for the students ${ }^{1}$ :

Student A: "To be religious is very important, because religion is our guide in life."

Student B: "I think religion has a very important role. A person needs a guide in his/her life which is religion."

Student C: "Religion was not created in order for people to fight with one another because the hearts of people cannot be forced."

\footnotetext{
${ }^{1}$ All extracts from the Secret Box were anonymous, so I cannot attribute any statements to participants beyond naming their school.
} 
Reflecting views of the majority of students from Jakarta Madrasah High, Cici (F, Protestant, 16yrs) a student from Jakarta Public High, speaks of the importance of religion to constructing morality: "Without religion we can't have morals. People have morals because they have religion in them. No morals, no religion." Cici's classmate, Marche (F, Muslim, 17yrs), expands on Cici’s view: "[Religion] is important because in Indonesia's culture religion has become the most fundamental guide." There were, however, a small number of students who did not accept the majority view that religion is needed in order to acquire moral values. For example, Dede (M, Muslim, 16 yrs) a student from the Jakarta Public High asserted:

Well I don't support that views must be from religion. When I saw the Japanese tsunami, many of them do not have religion. Seeing from the news they are very orderly, evacuating in order, whereas religion is not something principal for them. If we look at Indonesia most are Muslims, the lack of morals can be seen, most are bad. (Dede, M, Muslim, 16yrs)

Dede's statement provides a critical view of how morality is acted upon outside the Indonesian context which is often built from religious knowledge. It shows how Dede has constructed his own knowledge and understanding of the concepts of morality through his own experience, echoing Dewey's (1916) view of how knowledge is experientially constructed. Dede's peer Gse, (F, Protestant, 16yrs) reaffirmed Dede's view: "I think people can have morals, be kind and polite even if they don't have a religion. I think they can.”

Similar to the majority of students from the previous schools, three students from the Jakarta National High provided information on how they saw religion as having a significant role in defining and maintaining a purpose in life, and as well as being a foundation of morality:

Marino (M, Catholic, 17yrs): "[Religion is] important. Religion is our purpose, when we are defeated we have to go there."

Janie (F, Muslim, 16yrs): Religion is a purpose in life. A purpose, if we don't have religion.. um ..well, the point is a purpose in life."

Susi (F, Muslim, 18yrs): "Well morals are based on religion 'because' (English word used) religion 'is everything' (English word used). If we don't have religion what should we do?" 
The secret box technique that I used immediately following the students' focus group interview at Jakarta National High provided further information on perceptions regarding religion and morality. Many either stated or reemphasised religion's role as a guide in life:

Student A: "Religion for me is important because a human who has no religion will not have a purpose in life and a purpose for the future."

Student B: "The obligation to be religious is when religion becomes the only thing we can hold on to when we need help but no one can understand. Because we can only ask something to our creator."

Student C: "To be religious is to have a guide in the afterlife."

Student D: "Religion is the guide in life for everyone. A person living without religion is a fool!"

Student E: "Religion is a life guide for everyone who sees that there is a religion."

Despite the majority of students from Jakarta National High agreeing on the need for religion in constructing an individual's moral values, one student provided an alternative view of religion in relation with morality. Vino (M, Muslim, 16yrs) from the Jakarta National High stated, "For westerners, their morals are based on law? That means their religion is the law. That can work." Looking at the participants from across the three schools, the majority of both the teacher and the student participants agreed on the necessity of having religion to construct an individual's moral values. Only a minority of participants critiqued this relationship between religion and morality. Notably, no students from Jakarta Madrasah High critiqued the necessity of religion as the foundation of learning moral values.

\subsubsection{Views of religious education in schools}

This section reveals the views of teacher and student participants concerning religious education in schools. A majority of the teachers and students agreed on the need to have religious education as a way of not only teaching religion itself, but also the 
moral values that come with it. It must be noted however, that when asked about their views of religious education, teacher and student participants across all the three schools elaborated more on the role of religion in constructing moral values than elaborating on religious education specifically. As discussed in the previous section, this may perhaps be due to how most of the participants saw a tight connection between religion and moral values. However, some participants were able to provide specific insights on their views of religious education. A citizenship education teacher from Jakarta Madrasah High, Budi (M, Muslim), explains the need for having religious education in schools:

It's very important in order to change the moral character of the students into what is envisioned by Indonesia, so that the student will be pious and will socialise correctly with others and with their environment. (Budi, M, Muslim, citizenship education teacher)

Budi's colleague Arman (M, Muslim), an Islamic education teacher, gave a similar opinion: "religious education must always be in our curriculum, because even with it the result of our education is already like this, can you imagine if we don't have religious education?" Through this statement, Arman is suggesting that there is moral inadequacy amongst the students. He further suggests that matters may become worse if the students aren't equipped with a religious foundation.

A teacher from Jakarta Public High also provided some insights on religious education. Ibnu (M, Muslim), an Islamic education teacher, sees religious education as a method of bringing balance in knowledge: "Personally, I think religious education is a balancer. It brings balance in knowledge. It is not only a mere science but a director of the students' knowledge."

Both teachers from Jakarta National High also commented on religious education within schools. Ucok (M, Protestant) a citizenship education teacher sees religious education as necessity in a religiously diverse country such as Indonesia: "In order to have good relations among religions in Indonesia we must have religious education. Sukono (M, Protestant) a Christian education teacher, questions having religious education in schools. His pragmatic view on this issue is:

Personally I think, when it comes to religious education for Christians, due to the wide range of denominations in Christianity, I prefer to have no religious education in schools. Religious education should be done in their respective churches. (Sukono, M, Protestant, Christian education teacher) 
Some students also provided insights on how they saw religious education; many saw the importance of having religious education not only to learn moral values but also to learn their personal religion correctly. Adhung (M, Muslim, 19yrs) a student from Jakarta Madrasah High explains:

Religious education is really important, because if we don't study what we believe in it will not come out right. Because of that we have to study until we really understand so that then we can believe in it... Sometimes the teacher explains about religious tolerance and relations with other religions, what other religions are like. We learn this so that we don't misunderstand other religions. For example when there is a conflict, what are other religions actually teaching? Without us knowing, we can make things worse because of misunderstandings. Having a teacher explain to us this is what happened, this is what historically influenced it makes us not misunderstand and that's enough. (Adhung, M, Muslim, 19yrs)

Similarly, Gege (F, Muslim, 18yrs) stresses how she learns values from her religious education: "Studying religion is broad, not everything is just about religion. We study tolerance between people, so that we can value other peoples' feelings so that we don't become negative towards them. It's important." Gege's peer Fitri (F, Muslim, 16yrs), reiterated Gege's opinion: "Well, the thing is we learn about tolerance from studying religion." Nuy (F, Muslim 16yrs), added to Fitri's statement by pointing out the inadequacy of learning non-religious knowledge, "I think studying religion is important because within religion there is information about our daily lives. In schools, the usual subjects only study about human knowledge. Our relationship with God we learn in religion."

Three students from Jakarta Public High reflected on the role of religious education and showed their dependence on teachers for knowledge. Azura (F, Muslim, 16yrs) states: "I think to have it in the curriculum doesn't really matter. It depends on how it is delivered." Cici (F, Protestant, 16yrs) elaborates on Azura's statement: "Teachers must be as objective as possible in teaching religion." Thomas (M, Muslim, 16yrs) expanded on Cici's and Azura's views:

In the religious classes, it should be delivered whole-heartedly, not half-heartedly, or mixed with the subjective opinions of the teacher, because the meaning will change. In the 
fanatical teachings, the students follow the views of the Kiyai (religious teachers) not the true teachings themselves. (Thomas, M, Muslim, 16yrs)

The religious education curriculum is still situated using a confessional basis (Parker, 2008; Pohl, 2011), and encourages a citizenship education curriculum still employs a rote-memorization, minimal interpretation and the passive transmission of knowledge (Kerr, 1999) (see Chapter Two). Adhung (M, Muslim, 19yrs) from Jakarta Madrasah High, and the students from Jakarta Public High, were highly dependent on the teachers for guidance and knowledge. The statements made by these students above show the importance of effective teaching, and also show how students require more than just an effective curriculum for learning. Students from the Jakarta Public High also showed reliance on teachers performing a central role in teaching religion. This is in keeping with Sim (2010), who argues that teachers are crucial 'gatekeepers' to the curriculum and their effectiveness cannot be separated from that of the curriculum.

\subsection{Religion, citizenship and identity}

This section examines the relationship between religion and citizenship, as the development of Indonesian citizenship has always been intertwined with religion (see Chapter Two). In addition, this section also examines how both the teachers and students define their national identities, as citizenship is always tied to questions of belonging. National identity has often been limited to a group of people who are defined as belonging to an imagined national community, which is constructed through a national discourse (Anderson, 1992). Yet when asked about their identities, both teacher and student participants provided a variety of answers that were not limited to a single personal identity but a repertoire of different identities.

\subsubsection{Religion and citizenship}

Religion has always been entwined with the process of citizenship in Indonesia (Kuipers, 2011). From the historical development of the nation through to the construction of the Pancasila and the constitution, religion has become an anchor that 
underpins Indonesian law (Maarif, 2008). In managing religion and their sense of citizenship, participants showed how they personally negotiated their citizenship with their religion. This they deemed necessary, as citizenship and religion support one another: this was consistent across all three schools. Arman (M, Muslim) an Islamic religious education teacher from the Jakarta Madrasah High, saw the need of learning religion as it is aligned with the national needs of Indonesia:

[Religion] is important in order to change the character of the students so that it is aligned with what is desired by the people of Indonesia, which is to be a student that has a noble character and can socialise properly with their peers in any environment. In essence, it is so that they become useful not only for themselves but also other people around them. We become devout not only for ourselves but also socially as well, for the family and the environment around us. (Arman, M, Muslim, Islamic religious education teacher)

Reiterating the findings of Parker \& Raihani (2011), citizenship education teacher Rani (F, Muslim) from Jakarta Public High described how she saw the relationship between citizenship education and religion,

Citizenship education and religion are one; they both emphasize faith. Citizenship education has faith in values which it considers good, religion has faith more in the spiritual. It will be much better if the values within religion are supported by the good values within citizenship. (Rani, F, Muslim, citizenship education teacher)

Ucok (M, Protestant) a citizenship education teacher from the Jakarta National High, expanded on this view of religion, looking at Indonesia's constitution and laws when discussing religion's importance,

Religion is important because our country is based on article 29 (of the 1945 constitution). Looking at article 29 paragraph 1, Indonesia is based on the 'belief in God almighty' which means the country is based on the belief in God, but is not a theocracy. Indonesia has a total of 6 religions that are acknowledged and in order for the religions in Indonesia to be able to live with each other there must be religious education. (Ucok, M, Protestant, citizenship education teacher)

Since religious studies became a compulsory subject following the failed 1966 communist coup (see Chapter Two), it has become one of the essential underpinnings of 
how students learn values, including citizenship values (Parker \& Nilan, 2013). Students recognised this role. For example Adhung (M, Muslim, 16yrs) from Jakarta Madrasah High stated that "Studying religion is broad, not everything is about religion. We study tolerance between people so that we can value other peoples' feelings... so that we don't become negative to them. It's important." Gege (F, Muslim, 18yrs), also a student from the Jakarta Madrasah High specifies, "Well, the thing is we learn about tolerance from studying religion.” Meanwhile Nolan (F, Muslim, 16yrs), from the Jakarta Public High, saw Indonesia and religion as inseparable, which "is important because in Indonesia's culture, religion has become the most fundamental guide." Agreeing with Nolan, Gse (F, Protestant, 16yrs) goes on to describe this in greater detail: "From TV shows there are many racial things, like talking badly of other religions. If a small kid sees this they will be violent towards their friends. This is not Indonesia's culture."

The responses of the students showed how they have used religion as a defining factor in how they act regarding societal issues, thus showing the importance of religion for the students in acquiring and maintaining their values. This mirrors Parker \& Nilan's (2013) findings which have also found this relationship between an individual's religion and values in other cities in Indonesia.

\subsubsection{Citizenship and identity}

All six teachers across the three schools described how they had multiple identities rather than one singular identity. Five of these six teachers insisted that their national identity was their primary identity with either their ethnic/cultural or religious identity as their secondary identity. This phenomenon of multiple identities shows that they had a complex understanding of identity. Ade (M, Muslim) an Islamic religious education teacher from Jakarta Madrasah High, provided insights on his multiple identities: "I am a Muslim who lives in Indonesia, I am also of Javanese (ethnicity) decent. But essentially I am an Indonesian who is a Muslim.” Fredy (M, Muslim), a citizenship education teacher from Jakarta Madrasah High, elaborates on how he viewed this multiple identity issue:

Well I am Muslim, but my nationality is Indonesian, meaning I still embrace Islam but we 
must also be able to just loosen up on this. I am a Muslim but I must also have nationalism. We can never progress as nation if there is no similarity amongst religions. (Fredy, M, Muslim, Jakarta Madrasah High)

Fredy's view reflects the notion of national identity in relation to subjects, where national identity is as a shared phenomenon that unites people within a nation (Kelman, 2001; Korostelina, 2007). However, the existence of a unifying force is not solely inherent in the concept of national identity, as religion is also a unifier that may even transcend beyond national boundaries (Roy, 2004). One citizenship education teacher from Jakarta Madrasah High, Budi (M, Muslim), echoes Roy's views on religion as a unifying factor:

It is Islam that unites us not ethnicity or race. As long as we are Muslims they are our brothers or sisters. Religion is the one thing that unites us not ethnicity or race or others. Therefore as long as we are Muslims, from whatever ethnicity or race that person is from, we are obliged to help and protect. (Budi, M, Muslim, citizenship education teacher)

Teachers from Jakarta Public High also provided insight into their multiple identities. Ibnu (M, Muslim) an Islamic religious education teacher from Jakarta Public High, revealed how he perceived his identity:

I tend to be nationalistic, because I've learned from experience. Since we're human beings, it is better and wiser of us if we can mingle and be accepted in all elements of society. Meaning that if I come to Papua I will condition myself as someone who is also the owner of Papua. If I go to Sumatra I will condition myself as a Sumatran. What I mean is the foundation wherever I go is Indonesian. (Ibnu, M, Muslim, Islamic education teacher)

Rani (F, Muslim) a citizenship teacher from Jakarta Public High provided similar insights to Ibnu as to how she perceived her identity:

When I'm alone, well, this is me. When I meet someone like you who also comes from Bogor (name of city) I get the 'chemistry'. We're similar but it doesn't we have to go overboard on this similarity. When I meet another Javanese I feel the same. When I meet people they're all Indonesians because this is Indonesia. That's it. (Rani, F, Muslim, citizenship education teacher)

Teachers from Jakarta National High gave similar views regarding their identities. 
Ucok (M, Christian) a citizenship education teacher from Jakarta National High, provides similar views on identity:

In my own environment I can say that I am Bataknese (ethnicity) or Christian but when I am out from this environment it is not that which I will highlight, not religion or ethnicity but the Indonesian identity. (Ucok, M, Christian, Jakarta National High)

Ucok's colleague, Sukono (M, Christian) a Christian religious education teacher, provided insights of not only his identity but also how he managed his national identity as his prime identity and his secondary religious identity: "my nationality is Indonesian, yet as a person of faith our individual faiths must also be shown in our nationality, even though we love our country... and because we love our country we must show by showing the colours that our country has."

These teachers showed that though they hold multiple identities most have maintained their national identity as their primary identity. This, however, does not indicate that they have dismissed their secondary identities, whether it be their cultural or religious identity, but instead merely illustrates that the national identity remains the unifying and most significant one. According to Kelman (2001), national identity is constantly reconstructed to serve several functions: to provide a sense of uniqueness and unity as well as a sense of belonging to a group. Five out of six teachers provided answers that showed their identification spoke of their national identity as their primary identity, with their cultural or religious identity coming second. This shows how a majority of the teachers viewed the significance of their national identity as their prime unifying identity within the Indonesian context.

Similar to the perceptions of the teachers above, student participants also held religious, national and cultural identities simultaneously. Like Fredy, not all student participants insisted that their primary identity was their national identity. However, in contrast to the teachers, some student participants expressed more of a cultural identity, or identity based on the city they are living in at the moment. 
Of the four students from the Jakarta Public High, two explicitly expressed that their identities were more religious in nature, and two addressed their tendencies to identify on the basis of nationhood. Marche (F, Muslim, 17yrs) saw religion as her main identity: "I see myself as a Muslim because I have inherited this from my parents. I've been taught that if you study a lot but do not pray, it will be equal to nothing. That is why I feel more like a Muslim." Nolan (F, Muslim, 16yrs) provided similar views when it came to her identity: "I'm still a teenager, in my everyday life I pray, I am still about my religion and religion in everyday life. Maybe when I enter society it will make better 'sense' (English word used). For now it's just like that." This outlook on their religious identity may perhaps be a sign of the growing religiosity of Indonesians (Hefner, 2013; Parker \& Nilan, 2013; Pohl, 2011). In regards to this, some participants also voiced their concerns about the problems of religion and identity. An anonymous student from Jakarta Public High wrote his/her worries through the secret box method:

Indonesians generally still see their religion as their identity and as something they must defend. But this has produced a fanatical, narrow mind-set where every individual assumes that their faith is the truth or the most correct and the faith of others is wrong. This has triggered minor discriminations such being as exiled or excommunicated from society and also perhaps heavy forms of discrimination such as the closure of religious places by force and physical violence. This I think causes riots in many parts of Indonesia. (Anonymous, student, Jakarta Public High)

This student is questioning the danger of a very tight link between religion and identity and hinting that a broader vision may be necessary.

In contrast with the two religiously oriented students above, two other students from the Jakarta Public High showed their inclinations towards national identity. Student Dede (M, Muslim, 16yrs) from Jakarta Public High explains, "I love the motherland. To be Indonesian is to appreciate many differences. Regardless of differences, we are all Indonesians." While Gse (F, Christian, 16yrs) also from Jakarta Public High elaborates:

I see myself as an Indonesian because every day I use the public transportation and meet people, I know they are my brothers of the same nation. I have the duty to make this world 
a better place. Every day I see bad news I feel that I have a responsibility to do good. My dream is to fix Indonesia. (Gse, F, Christian, 16yrs)

All six students from the Jakarta National High provided succinct answers when asked about their identities, and also spoke of their identities in personal terms:

Vino (M, Muslim, 16yrs) : : "I'm my hometown, Jakarta."

Susi (F, Muslim, 18yrs) : "I see myself more as my religion because religion is the strongest one for me."

Marino (M, Catholic, 17yrs) : "I am confused; don't really know what it is."

Janie (F, Muslim, 16yrs)

: "I'm 'balanced' (English word used). In the middle (national, religion and cultural-ethnicity)"

Liwan (M, Muslim, 16yrs) : : "I'm a Padangnese (ethnicity)"

Godzilla (M, Muslim, 18yrs) : "I'm a Jakartan, that's where I was born."

The students' perceptions of their identities were primarily related to either their current city of residence (two students) followed by their ethnicity (one student) or religious background (one student). The other two provided no primary identity, and showed either uncertainty or a struggle to negotiate their multiple identities. In addition to this, no one in this school expressed that their national identity was their primary identity.

Similar to these two students from the Jakarta National High, none of the students from the Jakarta Madrasah High claimed national identity as their primary identity. Adhung (M, Muslim, 19yrs) indicates that his identity is dependent on his cultural area or city of origin: "personally, for an issue such as this (identity), I always say where I come from." While another student, Gege, stated that her views on identity are dependent on her current place and situation:

For me, I'm balanced. Nothing really prominent, especially in sociology (meaning within a social context) there is a social difference. For instance when it comes to nationalism and religious identity we can differentiate which is which. It depends where we are, so there is not a single one that is prominent. (Gege, F, Muslim, 18yrs)

The ambiguity of some of the statements from students from the Jakarta National High and the Jakarta Madrasah High relates to the fluidity of an individual's identity; although people do generally maintain continual identities they are nevertheless dependent on their social contexts (Mitchell \& Parker, 2008). However, the way people 
claim a particular identity as their chief identity may affect their actions and perceptions, and how they see their secondary identities in relation with their primary identity (Burke $\&$ Stets, 2009). Although we can speculate that the sum of the individual is based on their dominant identity, we can never fully understand a person's actions or perceptions based solely on how they perceive their identity (Burke \& Stets, 2009). This raises a number of challenges for the teaching of religious education and citizenship in schools throughout Indonesia. This will be discussed in greater depth in Chapter Seven.

\subsection{Chapter conclusion}

All of the three schools demonstrated the importance of religion, either reflected by the religious facilities within the schools or the attitudes of the teachers and students towards religious matters. Although some teachers and students showed a more secular understanding of their moral values thus producing a more secular understanding of their citizenship, many of the teachers and students also affirmed the need to study religion. This is done not only as an intellectual knowledge per se, but also as a moral guide in living life. Thus how these teachers and students construct their sense of citizenship is grounded in their personal views on their religion. This has resulted in an entwinement of the religious and citizenship values held by the teachers and the students, producing a 'religious citizenship' (Hudson, 2003; Miedema, 2006; Parker, 2008; Parker \& Hoon, 2013). The following chapter elaborates on the second research question, which looks at perceptions of participants regarding religious tolerance, and will explore how the teachers and students define and practise religious tolerance. 


\section{CHAPTER 6: SECONDARY SCHOOL TEACHERS'AND STUDENTS' PERCEPTIONS TOWARDS RELIGIOUS TOLERANCE}

\subsection{Chapter introduction}

While the last chapter examined the teachers and students perceptions of religion, citizenship and identity, this chapter focuses on their perceptions of religious tolerance addressing my second research question. The chapter begins by looking at the definitions of religious tolerance in the curriculum, and those provided by the teachers and students. Section 6.3, through interview sessions and the secret box technique, examines how teachers and students perceive religious tolerance and the value they place on it. This section also illustrates participants' concerns about teaching and learning religion, and provides insight into some of the participants' experiences regarding issue of religious diversity, and then concludes the findings in section 6.4

\subsection{Defining religious tolerance}

In this section, I examine how religious tolerance is defined in the curriculum, and by the participants from the three schools. Teacher and student participants gave similar definitions of religious tolerance. All of them defined tolerance as either forbearance or mutual respect as a means of addressing differences, which is largely in line with the understandings of tolerance outlined in the literature (see Chapter Three). This is also closely aligned with how the Indonesian curriculum defines religious tolerance. In addition to this, the curriculum and some of the participants saw the need of using religion as a reference point in defining tolerance, as religion is the foundation of their values, as discussed in Chapter Five.

The understanding of how one should approach religious tolerance as prescribed by the curriculum was commented on by the teachers as well as the students. Arman (M, 
Muslim), Islamic religious education teacher from the Jakarta Madrasah High described it this way:

Tolerance between Islam and other religions does exist, but it cannot be generally applied to all fields. For instance when it comes to our own faith, there is no tolerance because lakum dinukum wa-liya dini (to you be your way, and to me mine from Chapter 109, verse 6 of the Qur'an). Thus when it comes how we conduct our religion there is no tolerance. However in socialising there is tolerance. It is even encouraged to be useful for others even if they are not Muslims, but if they need help socially we are required to help them. It's obligatory, not merely suggested. It is the basis of humanity. Not only human beings, but also animals and plants: in helping there is tolerance yet not in our religious practice. (Arman, M, Muslim, Islamic education teacher)

Arman's statement about religious tolerance revealed a double standard. Tolerance, as defined by Arman, must be limited to social fields. Issues regarding how his religion is conducted, which I assume are his core religious values, must be adhered to and cannot be wavered from. This definition of tolerance poses a problem, as we can see in Chapter One where different Islamic sects that are outside the majority denomination are often discriminated against, as a result of this inflexible definition of tolerance. Ade (M, Muslim) also an Islamic religious education teacher from the Jakarta Madrasah High expressed this view as well:

It must be clear what tolerance is, what tolerance means. In religion we have to be firm, that his religion is his religion and mine is mine, roughly it's like that, brother. But tolerance pertains to other things, of course it is, but in religion we have to be firm so that it is based on the rules in the Qur'an. (Ade, M, Muslim, Islamic religious education teacher)

While Fredy (M, Muslim) a citizenship education teacher from the Jakarta Madrasah High, gave a more flexible understanding of religious tolerance. He asserts that religious tolerance is also about respecting one another: "[Religious tolerance] is letting people be, basically it is based on the majority/minority principle. Valuing the majority and the majority also accepts the minority, valuing the minority...essentially it's about appreciating each other." 
Ibnu (M, Muslim), an Islamic religious education teacher from Jakarta Public High sees that teachers need to expand the definitions of religious tolerance while still keeping with what has been written in the curriculum:

The curriculum only gives the basic concept, basic understanding. The rest depends on the development of each teacher. How the teacher understands it or defines tolerance as written in the curriculum. Well basically it's lakum dinukum wa-liya dini (to you be your way, and to me mine from Chapter 109, verse 6 of the Qur'an). It is not about accepting the truth of all religion. There is only one truth. So when it comes to tolerance, in accordance with accepting the truth of other religions I say no, but when it comes to accepting that there are different and diverse religions I say yes. (Ibnu, M, Muslim, Islamic education teacher)

Ibnu's statement is similar to Arman's understanding of religious tolerance, not only in terms of how they define religious tolerance, but they also referenced the same verse from the Qur'an in defending their perceptions.. It must be noted that using this particular verse for giving an explanation of religious tolerance is a popular habit in Indonesia. Ibnu's statement reflects a point made by Sim (2010), that suggests that teachers are gatekeepers between the curriculum and how it is implemented in the classroom. Sim believes that teachers have a central "role [in] what is taught and how it is taught in classrooms" (p. 226). This importance of the teachers' roles as gatekeepers of knowledge will be elaborated on further in Chapter Seven.

Sukono (M, Protestant) a Christian religious education teacher from Jakarta National High drew similar conclusions, yet he also expresses his concern as there is no clear definition on what religious tolerance actually is:

Tolerance of religion is good as long as we are limited by the rules available. But speaking of our own state, tolerance is not tolerance in Indonesia, actually. Tolerance should be the right to mutual appreciation. Tolerance is the way of respecting that diversity. There is a diverse range of religions and we must understand and accept that. The meaning of tolerance in our state is rather blurry because the religious leaders themselves have not given a definite definition of what it means to be tolerant. It does not mean we let go of our faiths. When we tolerate one another we open the opportunity for someone to do what they wish to do. (Sukono, M, Protestant, Christian religious education teacher) 
Sukono expressed his dissatisfaction with how religious tolerance plays out in society, as it is marred with ambiguities. He hoped that religious tolerance is carried out with the understanding of forbearance and letting others be, yet recognises that just how this occurs is rather unclear. In addition to this, Sukono also sees that tolerance involves the entitlement of others to freedom: "When we tolerate one another, we open up the opportunity for someone to do what they wish to do...to have faith in what they wish to have faith in. We are not limiting that freedom." This statement by Sukono, a minority Christian, reveals differences to the views of the Muslim teachers, who are in the religious majority in terms of the Indonesian population. While the Muslim teachers shared a rigid and qualified definition religious tolerance, Sukono provided a more open view of how religious tolerance should be defined and carried out.

Students mirrored this view closely. The first activity the focus groups conducted was to define religious tolerance together:

Jakarta Madrasah High: To respect one another and to respect the feelings of others even though they are of a different religion.

Jakarta Public High: By not making religious differences a problem, we do not disturb one another, we live in peace even though others' religion is different. Tolerance involves not forcing one's own ideas/religion on other religions. Because we might be wrong in our religion, God is unpredictable.

Jakarta National High: Allowing the majority of the religious people to coexist in one environment and freedom in society to choose a religion.

The data acquired through the group activity provided similar definitions of religious tolerance. In contrast to the majority of the teachers, students defined religious tolerance through open and neutral understandings. This suggests that students have not merely imitated their teacher's views of religious tolerance, but have constructed their own personal definitions of it. However, looking at their responses we can see that the general definition provided by the students of religious tolerance is limited to the concept of forbearance. Parker (2010) points out, however, that tolerance is not a very positive concept to begin with, as it is a shallow way of dealing with differences. This also reflects Newman's (1982) argument that tolerance should go beyond mere tolerating, or in his own words: "[Tolerance is] to accept or endure that thing without reacting strongly to it. 
To tolerate it is to bear it, to put with it. It is not to like or respect it" (p.4). This understanding of tolerance has been described by May (2006) as "only the kindergarten of the kind of interactive pluralism we now need, not only in democratic nation states but in the global civil society that is slowly but surely emerging" (p.11). In the following section some of the tensions which underpin these definitions of religious tolerance are explored further.

\subsection{Perceptions and practices of teachers and students regarding religious tolerance}

Across all three case study schools, teachers and students showed a high level of agreement as to the importance of teaching religious tolerance within schools. In this section I examine how tolerance was perceived as a necessity in managing diversity and national unity by all of the three schools, which is seen to be a key benefit of religious tolerance (Miller, 2000; Newman, 1982). I also examine concerns about teaching and learning religious tolerance, and relate the experiences of some the teachers and students in situations pertaining to religious tolerance that paint a less promising picture.

\subsubsection{Tolerance as a necessity for managing diversity and national unity}

When asked about the reasons behind the need for religious tolerance, managing diversity and national unity were repeatedly cited as key rationales. All participants described how they perceive religious tolerance as an invaluable tool for maintaining national unity, and for living in a religiously diverse society. Let us first look at the Jakarta Madrasah High, as it is a religious school and thus, has a less diverse staff and student population. It has been argued that religious schools are unlikely to be able to prepare students for encountering and managing religious diversity, due to the homogeneity and lack of exposure to other religions (Kymlicka, 2001; Parker, 2008). However, teachers and students did not appear to find themselves lacking in exposure to religions different from their own: as the data suggests they clearly mingled with nonMuslims outside schools. 
As previously mentioned, religious tolerance in Indonesia has become one of the main methods of dealing with issues of religious diversity. Budi (M, Muslim) a citizenship education teacher at the Jakarta Madrasah High, provided some insights into the relation of religious tolerance to diversity and national unity:

[Religious tolerance] is very important because Indonesian society is known for its pluralism right? If we think this is something that is not important, then the Republic of Indonesia will be no more. It is so easy to use issues of SARA (an acronym for Suku ethnicity, Agama - religion, Ras - race and Antar golongan - interclass) these days. (Budi, M, Citizenship education teacher)

As discussed in Chapter One, with the growth of Islamic conservatism, Indonesia has witnessed a myriad sectarian conflicts and religiously based terrorist attacks in recent years. What Budi describes is how issues of SARA have played a continuous part in inflaming sectarian problems. Budi further states: "Whatever the case, the majority of Indonesians are Muslims but I, thank God, have a tolerance level that is quite high because I had live in an environment that is more colourful in terms of religion and ethnicity." Arman (M, Muslim), an Islamic religious education teacher from Jakarta Madrasah High, drew similar conclusions: "when it comes to religion, tolerance is needed because we do not live alone. Because we live in a social world, that's why we need to be able to tolerate." What Arman and Budi acknowledge is the difference and diversity within Indonesian society, and that tolerance is needed in order to address the issues that may arise due to these differences. This reflects Newman's (1982) assertion that tolerance is a method of establishing a peaceful co-existence in a civilised way, between individuals with different faiths, beliefs and points of view.

During the focus group interviews, four students from the Jakarta Madrasah High expressed similar understandings of the importance of religious tolerance. Gege (F, Muslim, 18yrs): “[Without tolerance] we might think negatively of someone else, and have prejudices towards that person." Kingdom (F, Muslim, 16yrs) agreed that religious tolerance is important and elaborated with her own personal experience in coping with religious diversity: 
I have a cousin who got married to someone that has a different religion and he/she changed his/her religion. I asked my parents, if I should hate him/her for this? My parents said no you don't, because we live in Indonesia not an Islamic country. Even if the majority are Muslims, there are other religions as well. Indonesia is country based on laws. You can't force someone's religious views because we have laws for religious freedom. My mother told me to think about the good things I can do for my religion. My religion is my religion, your religion is your religion. (Kingdom, F, Muslim, 16yrs)

Adhung (M, Muslim, 19yrs) from Jakarta Madrasah High shares how he learned and acted upon dealing with religious diversity through personal engagement:

My house is near a friend that has a different religion than I do so we hang out often. I learned religious tolerance from there, from hanging out. My family is Muslim but my friends, the people I hang out with are different. Even if I'm a Muslim I often think that many other religions are nicer than us. We can't say which one is the best one. Which one is the correct one, Christian or Muslims?. (Adhung, M, Muslim, 19yrs)

Adhung's classmate, Nuy (F, Muslim, 16yrs), has had similar experiences:

I have neighbour who's Christian. When we've done something wrong he/she gives an answer/advice based on his religion. We respect that and if she/he's done wrong we will also explain it to him/her based on our religion. So we respect one another. (Nuy, F, Muslim, 16yrs)

The experiences of Kingdom, Adhung and Nuy from Jakarta Madrasah High show how they have constructed their understanding of religious tolerance not only through the knowledge they have gained in classrooms, but also by lived experiences outside the classroom. They have not merely talked and theorised about religious tolerance, but have constructed their understanding by practising it in their everyday lives. This aligns with how Dewey (1916) sees knowledge, where learning and knowledge are constructed through action and experience, and that no learning takes place without action by the learner. As Kingdom, Adhung and Nuy have had positive experiences in their practice of religious tolerance, this also reflects the views of Wood (2013), where citizenship identity and the practices that come with it, are constructed through an individual's emotional experiences. As Wood (2013) further suggests, 
"emotions can serve to spark, shape and sustain citizenship practices." (p.51)

Similar findings can be seen from the secret box activity deployed with the students of Jakarta Madrasah High. This anonymous method of data gathering provided deeper insights into their perceptions on the necessity and benefits of religious tolerance:

Student A: "Because there are a number of different religions, every human being has the right to choose what belief they wish to hold on to. The numbers of religions and the choosing of one religion do not mean we speak ill of other religions. One religion must respect another in order for harmony in a country."

Student B: "Religion has never limited us in socialising. My parents have taught me to respect others even though we might have different religions because we are all the same in the eyes of Allah."

Student C: "In our country, it is stated in our Pancasila that there is to be "belief in the one almighty God', which can be understood as people freely embracing their religion. Tolerance between religions is very important, with tolerance there will be peace."

Student D: "In essence tolerance is to respect every human being in the same way, even though there are differences in religion. We cannot look down on each other." Student E: "In everyday life, the bond of religion and tolerance is very tight. Why? Because religion without tolerance will not go well in many life events and in social interactions between people. In finding a friend we should not look at their religion, we should remain together even if we have different religions."

Student F: "It is our heart's choice as to what to have faith in, without being forced by another."

What the evidence collected from the secret box method suggests is that the students from Jakarta Madrasah High are embracing an inclusive view with regards to religious diversity. This evidence is contrary to what Kymlicka (2001) claim about religious schools (such as the Madrasah) - that they will not have the ability to teach tolerance due their homogeneity. Instead, these findings are closer to what Halstead and McLaughlin (2005) argue, that there is no evidence to support that religious schools cannot teach students how to live with differences, and that religious schools can actually 
provide students with much needed inclusive values such as tolerance. Parker (2008) asserts that "faith schools could be creating secure identities in their students as well as building communities of empathetic citizens committed to the common good" (p.7).

Similar to the teacher and student participants from Jakarta Madrasah High, teachers and students from the Jakarta Public High agreed that religious tolerance is needed for managing diversity and maintaining national unity. Rani ( $\mathrm{F}$, Muslim) a citizenship education teacher from Jakarta Public High, discussed on the relationship between religious tolerance and a lack of unity:

Tolerance can happen when we accept pluralism. Without tolerance there will be disunity and disunity is not merely about wars. But it is also about the disunity in thought and paradigm: understandings which will then lead to us in having our own ways. (Rani, F, Muslim, citizenship education teacher)

Students from Jakarta Public High drew the same conclusions on the importance of religious tolerance. For example Dede (M, Muslim, 16yrs): "Because we are different, it is important to be taught of tolerance. So that we do not look for differences or the wrongs of other religions." Cici (F, Christian, 16yrs) reiterates Dede's view: "If people have different kinds of friends, people will understand their differences. Compared to people who enter a pesantren (religious boarding school), who like to judge people without actually knowing that it's wrong." Much like the participants from the Jakarta Madrasah High, evidence collected using the secret box method from Jakarta Public High provided further insights on this issue:

Student A: "I think religious tolerance in Indonesia is quite bad, not only between religions but specifically within a religion itself. It is as if we do not know what we should do when faced with difference. Many still think 'I am right and you are wrong'. In many ways, I think the reason for this is because religious tolerance is not acted on enough in schools. It should be a different subject from religion and civics."

Student B: "Religious intolerance I think should not happen. Because what's the point of bickering, feeling our religion is the truest, at its end only resulting in disunity between people. People should live in peace because God has told human 
beings to live in peace. We do not need to make a problem of people of different religions to us."

Student A from Jakarta Public High expresses views contradictory to the experiences of students' from Jakarta Madrasah High. Here the student notes how religious tolerance is insufficiently acted upon, indicating a negative experience of religious tolerance. They build on this by asserting that religious tolerance should have its own curriculum to emphasise its importance.

Teacher and student participants from Jakarta National High share similar understandings of why religious tolerance is needed. Ucok (M, Christian) a citizenship teacher of Jakarta National High puts it this way: "Tolerance is the way of respecting that diversity." Students from Jakarta National High were rather hesitant in sharing their views on religious tolerance. Only one student, Susi (F, Muslim, 18yrs), voiced her thoughts on religious tolerance: "we have to respect one another. Friends, family. Respect. Differences do not make it an issue."

The responses from the teacher and student participants across the three schools mirror what Newman (1982) and Miller (2000) have argued about the need for tolerance in a religiously diverse society, as a much-needed value to manage issues arising from religious diversity and to prevent violent acts of intolerance. Newman (1982) argues that religious tolerance, when viewed as a form of tolerating, enduring, and bearing, involves an attitude towards something that is not liked, loved, respected, or approved of: "it involves acceptance in the sense of refraining from any strong reaction to the thing in question; it is half-hearted". Yet as the evidence above suggests, although the word tolerance is used in managing diversity, the participants' views on religious tolerance may have gone beyond forbearance of a thing that they dislike. It has, in some cases, involved understanding, acceptance, and respect of difference rather than merely enduring (Muldoon et al., 2011) and includes friendship actions.

\subsubsection{Concerns about religious tolerance}

In 2005, the Indonesian Council of Ulama produced a controversial fatwa (religious edict) that declared pluralism, liberalism, and secularism to be opposed to Islamic values (Gillespie, 2007). Although a fatwa bears no legal weight as it is not a 
formal national law that must be adhered to by all, it does show the growing fears of the Islamic community in respect to dealing with religious diversity. As explained in previous sections, some participants, in line with the curriculum, expressed the need to have a theological framework for defining, utilising and stating the limits of religious tolerance. The cause of this seems to be rooted in the fear of losing one's faith, as religious tolerance has at times been feared as a progression towards religious relativism (Newman, 1982). Pohl (2011) reaffirms this, by pointing out the need for an Islamic theological framework as the grounds for religious tolerance. Pohl describes the rejection of religious tolerance by some religious conservatives as not merely a critique of secularisation and westernisation, but also a theologically motivated objection that religious inclusivity will lead to religious relativism and a weakening of the commitment to Islam.

Some of the participants, especially the Muslim participants, illustrated their concerns about teaching and learning religious tolerance. Along these lines, Arman (M, Muslim) an Islamic religious education teacher from the Jakarta Madrasah High, stated his views on the problems of tolerance:

Tolerance towards other things is alright but when it comes to religion we must remain firm and in accordance to the rules in the Qur'an. We must give clear limits to these people so that we do not get carried away with tolerance because with tolerance our faith may deviate. We can have tolerance in religion but everything must have its limits that we must take into account, in order for us not to be confused. Especially when it comes to faith. (Arman, M, Muslim, Islamic religious education teacher)

Adhung (M, Muslim, 19yrs) a student from the Jakarta Madrasah High addresses his worries about learning religious tolerance: "[Religious tolerance] can go the other way around, where we have so much tolerance that we lose our own faith." Although the data collected showed that only a minority of the participants explicitly expressed their concerns about the teaching of religious tolerance, other participants (as seen in section 6.2) were accepting of religious tolerance, provided it remains grounded within the theological framework of their respective religions. 


\subsection{Perceptions of religious discrimination}

One reason participants highlighted the need for education on religious tolerance was the discrimination they had experienced or witnessed. In section 6.3.1 we saw in one instance Budi, a teacher participant from Jakarta Madrasah High, was concerned with the easiness of using issues of SARA to exacerbate conflicts in Indonesia's diverse society. Expanding on this, participants, mainly students, also voiced their discontent about many issues concerning religious freedom and religious discrimination. Some also gave examples of how they have experienced discrimination and intolerance in their schools.

The Jakarta Public High, being an elite school, manages to attract to a diverse range of students with varying religious backgrounds. As explained in Chapter Two, a majority of the students were Muslim with a minority of Catholics, Protestants, Confucianists and Buddhists. Initial interviews with the teachers and students gave the impression that tensions between different religious backgrounds or ethnicities were nonexistent or minimal at the school. Yet evidence collected from the secret box method suggested that some minority students have experienced bullying due to either their ethnic or religious backgrounds. Two students voiced their concerns about religious tolerance through the secret box method. Anonymous Student A shared his/her story of disappointment:

I think religious tolerance in Indonesia is not yet good. One simple example is that in classes there is still religious and racial discrimination. To be honest I personally still think that there is discrimination, even if it is small things such as making fun of others. I come from Private Junior High School (an upper-middle income private school which mainly consists of Chinese-Indonesian Christians), from kindergarten to junior high; I am part of the majority in my environment. But when I entered Jakarta Public High at first I was very surprised and had a hard time adapting because I am now the minority in my environment. Every little instance of name-calling, I see it as inappropriate. I feel sad and I really wanted to move to another school. But I understand, as a minority, it is very much natural and understandable. Now I can adapt well and make friends without differences caused by race or religion." (Anonymous, student, Jakarta Public High)

Anonymous Student B also shared his/her story through the secret box method: 
Indonesians argue a lot about religious differences. Even the government is weird feeling that Islam is the truest religion. If there's any so called "false religion" that shows up it will immediately be banned. But no one sees Islam as a false religion. To be honest I do not understand what our government's rights are, why does our government have the ability to ban people from embracing the religion which they see as true? Why does everyone have to bow down towards laws if those laws push them away from the God they believe in? That means the government, with their laws, has brought society down a path that could be wrong. Indonesia is weird. Indonesia needs a lot of fixing." (Anonymous, student, Jakarta Public High)

Through this statement, Student B provides a rare insight as he/she critiques the issues of religion in Indonesia. Scholars such as Parker \& Nilan (2013) and Pohl (2011) have argued that religious radicals and intolerant groups are a minority in Indonesia, and the growth of Indonesia's Islamic religiosity is limited to the individual's religious and moral needs. Yet as the statement from Student B above suggests, some minority individuals feel that they have been discriminated against by the state with regard to issues of religious rights. This religious discrimination casts doubts on the state's neutrality in protecting minority rights, thus forcing individuals to question whether the state's policy of embracing both religion and secular-citizenship is the proper action to take.

This, however, does not reflect the position of the school. With the high diversity of students within the school, the Jakarta Public High officially condemns any form of religious, ethnic or racial discrimination and tries to foster tolerance among its students (field notes, 2013). The Jakarta Public High bases its approach to how it treats diversity on the state's national curriculum, which is specifically addressed in its citizenship education. The curriculum specifies that one of its aims is to "discuss and examine carefully the relationship between attitudes, tolerance and other moral values, as tolerance is needed to respect each other in order to create a peaceful life" (field notes, 2013). Evidence from Student A above nevertheless suggests that although the school and the teachers take a non-discriminatory stance, the practices of non-discrimination between the students are still lacking, as some still experienced religious or racial discrimination. 


\subsection{Chapter conclusion}

In summary, these findings have highlighted some of the tensions and contradictions, as well as commonalities in how teachers and students define religious tolerance and perceive the importance of education in religious tolerance in order to manage religious diversity. Although all the participants acknowledge that religious tolerance is needed for managing diversity, it would appear that some participants are cautious of it as well, as it may lead to religious relativism. In addition, the daily actualisation of religious tolerance still poses problems for some students and teachers in all three schools. Findings also showed that some participants constructed their perceptions of religious tolerance through friendship and social interaction outside their religious community, showing that their understanding of religious tolerance was part of their everyday citizenship identity. The findings have also shown that although the schools might seem different from ideological standpoints, they have engaged in religious tolerance in similar fashions, by negotiating both the secular-citizenship values and the religious values as advised by the curriculum itself. However, this curriculum policy, in trying to accommodate everyone, has ignored the problems and tensions that arise by merging the secular and the religious. This has at times resulted in individuals taking a biased stance when confronted with religious issues such as religious blasphemy, begging questions of how far religious tolerance should be conducted.

The findings in Chapter Five and Six have raised interesting questions. For instance, why have the teachers and students tried to negotiate between their religious and citizenship values, and how has this affected their understanding of religious tolerance? These questions are discussed in Chapter Seven. 


\section{CHAPTER 7: DISCUSSION}

\subsection{Introduction}

In Chapter Five and Six, I examined the views of secondary school teachers and students on religion, citizenship, identity and religious tolerance. The findings illustrated that most teachers and students from the three schools investigated shared similar understandings and commitments towards religion, which they saw as the basis of their moral values. Teachers and students also demonstrated how they intertwined their religious and citizenship identities, thus underpinning their citizenship values with a theological framework. In this chapter I will discuss in greater detail the intertwinement of the teacher and student participants' religious and citizenship identities, and what the implications of their different approaches to religious tolerance might be. I begin by reviewing the findings on religious and citizenship identity from the three schools, and follow by an examination of how these aligned with the concept of 'religious citizenship' (see Chapter Three). I then examine how this has affected the participants' understanding of inter-religious relations, concluding with the implications the findings have to the current state of citizenship.

The theoretical lens of social constructivism and constructionism used to guide this research has helped to shed light on the development of identity and religious tolerance within the schools. The following sections highlight the socially constructed nature of religious citizenship and religious tolerance, and how the citizenship values of the student participants in particular was shaped by schools, peers, teachers and personal experiences.

\subsection{The mediation of citizenship and religion}

In Chapter Five, I examined several factors that contributed to the construction of citizenship. These factors pointed to the significance of both a religious identity and a 
national identity in the formation of the participants as citizens. This is aligned with Miedema (2006), Parker's (2008) and Hudson's (2003) concept of 'religious citizenship', where citizens intertwine their religious identity with their citizenship identity. Findings in Chapter Five also showed that participants drew from both religion and secularcitizenship laws (such as the constitution) in defining their citizenship. In the following section I will review the findings on religion, identity and citizenship within the three schools in my study and compare these findings with those of Miedema and Parker, as well as other relevant studies. I will also discuss the implications of religious citizenship as defined by the participants.

Findings in Chapter Five suggested that the teachers and students negotiated their citizenship by being simultaneously Indonesian and religious. This was the case for participants from Islamic and Christian backgrounds. This ability to draw from both secular-citizenship values and religious values produces what is known as 'religious citizenship'. In essence, religious citizenship is about negotiating values; it is where citizens may "negotiate the perspectives of others and integrate such perspectives into their own actions and reflections" (Miedema, 2006, p.975). Through religious citizenship, citizens may draw upon either their religious values, as based on their religion's theological framework, or secular-citizenship from secular laws, or both. Although a number of student participants noted some tensions in trying to achieve this, in general these identities and the values they held were not in conflict, but mutually supported each other.

However, this new perspective on citizenship does not eradicate the individuals' religious, cultural or other forms of identity. Findings from Chapter Five revealed that the majority of the teachers and students across all three schools had multiple identities consisting of national, religious, ethnic, cultural or local identities. Looking at teachers from Jakarta Madrasah High, most displayed a more rigid and nationalistic understanding of identity. Although all three teachers elaborated on their multiple identities, they stated that it was necessary to essentially be an Indonesian first and foremost. They saw this national identity as a crucial unifying factor for Indonesians of diverse religious, ethnic or cultural backgrounds. However, one teacher, Budi (M, Muslim) a citizenship education teacher, stated that it was only religion (i.e. Islam) that 
can unite people of diverse backgrounds. In contrast, some students from Jakarta Madrasah High displayed more flexible views regarding their identity. Instead of stating the necessity of having a national identity as their primary identity, they indicated a fluidity to their identities, indicating that their identities were dependent on the sociocultural environment they found themselves in.

Similar to the teachers from the Jakarta Madrasah High, both teachers from the Jakarta Public High described their multiple identities and both saw the importance of a national identity as an underlying unifying factor amongst diverse groups of people. However, unlike teachers from Jakarta Madrasah High, both teachers from the Jakarta Public High exhibited a more flexible and inclusive form of identity. For instance, teacher Rani (F, Muslim), a citizenship education teacher, indicated that we have the potential to relate to people with similar cultural or religious backgrounds. While Ibnu (M, Muslim), an Islamic education teacher at Jakarta Public High, saw the need to be flexible in order to blend into the local culture, he also argued that the notion of being Indonesian could be the main unifying element for Indonesians of different social, religious, and cultural backgrounds. Contrary to their teachers, students from the Jakarta Public High were more rigid in their stances, as none of them described their identities as multiple - instead they had either a religious or national identity as their primary identity, but not both.

Similar to the teachers from Jakarta Public High, both teachers and students from Jakarta National High expressed flexible and inclusive understandings of their identities. For instance, Ucok (M, Christian) a citizenship education teacher, explained that although he is a Bataknese (ethnicity) and a Christian, when he is not in his cultural or religious environment he will emphasise his Indonesian identity. While the teachers saw their national identity as their primary identity, students from the Jakarta National High related to either their current city of residence (two students) followed by their ethnicity (one student) or religious background (one student), whilst the other two provided no primary identity and showed uncertainty about negotiating between their multiple identities. None, however, claimed their national identity as their primary identity. Interestingly, of the three schools, Jakarta National High is the only one that utilises a nationalistic approach in its founding philosophy. However, this did not appear to a strong factor for the students. Yet citizenship is not about embracing a single common identity nor is it 
about acquiring multiple identities but it is more about allegiance. As Irving (2007) argues that allegiance constitutes an individual's allegiance towards the state, the democratic institutions, tolerance and liberalism even without having the citizens embrace a single identity.

Using Irving's (2007) understanding of allegiance, religious citizenship can be seen as a way to address this issue of multiple identities by providing both teachers and students an opportunity to engage in both their religious identity as well as an allegiance towards the nation. Through this, the construction of religious citizenship straddles across the two spheres: the secular or nationalistic and the religious. The challenge is to take the positive elements of these two spheres, so that the individual is provided with the means to build an identity as a religious citizen that has allegiance towards the state, democracy and tolerance. However, although Indonesia's laws guarantee the same rights and status of religious citizen for religious minorities, recent cases have shown that this extends only to the six acknowledged religion. Religions and faiths outside these six, such as the Ahmadis and Shiah Muslims are constantly marginalized not only by the society but also through official state policies (see Chapter One).

What is interesting to consider then is how forms of religious citizenship are formed and what are the implications of religious citizenship for Indonesian society. To answer this I will firstly look at the perceptions of the teacher and students participants on how societal values were constructed as this is done with the understanding that citizenship is a form of values and is used as a reference point, to guide individuals or groups of diverse identities to find a way to live together politically (Irving, 2007; Miller, 2000).

One of the aims of the national education is to develop each student with faith and piety towards one almighty God and good morality (Kemendikbud, 2003). Religion therefore cannot be separated from the development of education as it is seen to be tied with the development of the nation and the lives of the people (Ali, 1974). This is reflected in Parker \& Nilan (2013) argument that young people's concern about religion is more about their own identity as a moral and devout individual, where adolescents are constantly asking themselves moral questions in regards to their religion, such as questioning "is this what a good Muslim would do?" These findings by Parker \& Nilan 
are reflected by most of the teacher and student participants across the three schools of my study, where they not only used religion but also agreed on its profound necessity as a basis of their values.

We can first see this in Jakarta Madrasah High where both of the citizenship education teachers saw the importance of religion as a fundamental tool in how to shape an individual's character or values. Likewise, both Jakarta Madrasah High's Islamic religious education teacher agreed on the importance of having religion as a moral guide and provided further reasoning by citing the Qur'an. Some teachers also noted their personal experiences of diverse societal interactions has helped form their understandings of religious tolerance as a much-needed value. Students from Jakarta Madrasah High also gave similar understandings of having religion as an important moral guide in their everyday lives, yet also expressed that their social interactions with individuals of diverse religious backgrounds has helped them address issues of religious diversity.

Mirroring Jakarta Madrasah High, most of the teacher and student participants from Jakarta Public High emphasised the need for having religion as the basis of their moral values. The Islamic religious education teacher, Ibnu (M, Muslim), saw religion as a reference point for values and concluded that all religions at its essence teaches good moral values. In addition to this Ibnu referenced the Qur'an in justifying notions of the importance of learning societal values such as religious tolerance. While Rani (F, Muslim) a citizenship teacher from the Jakarta Public High suggested that citizenship would be better developed when underpinned by a religious framework. While most students from Jakarta Public High agreed on the necessity of having religion as their moral values basis, some students questioned its sole dominance as a foundation of an individual's moral values. Drawing from his own critical conclusion of contrasting nonreligious people's behaviours in Japan and religious people in Indonesia, Dede (M, Muslim, 16yrs) believed it was unnecessary for people to have religion in order to be morally sound. Likewise Gse (F, Protestant, 16yrs) also concluded that people may have morals and respect of one another without having a religion.

Although a majority of teacher and student participants from the Jakarta National High agreed on the necessity of having religion as moral guide, some participants contested this view. Ucok (M, Protestant) a citizenship education teacher from the Jakarta 
National High contends that individuals that follow the laws and rules can behave morally. Student Vino (M, Muslim, 16yrs) also reaffirms this view and draws from his own experience on this issue: "For westerners, their morals are based on law? That means their religion is the law, that can do."

In sum both teacher and student participants from Jakarta Madrasah High saw religion as a fundamental necessity in learning moral values. While both the teachers and some of the students from Jakarta Public High mirrored participants from Jakarta Madrasah High, some students rejected the idea of values deriving solely from religion. Similarly, not all teacher or student participants from Jakarta National High agreed on having religion as basis for morality.

These comments show much more contested understandings of the importance of religion as the sole moral guide for a society than it might initially appear. While this study is only a small, qualitative research and further and further research would be required to established the depth of this vein of thinking in Indonesia, it does point to a group in Indonesia who are not willing to just accept the 'party line' on the connection between religion and morality, but actually draw on their own experiences of living in society and observing the world to form alternative and at times, more critical and inclusive views.

As the findings in Chapter Five and Six suggests, although a majority of participants stated that their values stem from their religion, many also revealed how they have constructed their values on issues such as religious tolerance through various means, most importantly, everyday experiences of social and educational interactions. This is in keeping with Dewey's (1916) notion of how knowledge is constructed through one's own experience and through social interactions with individuals of diverse religious backgrounds. However Kaufman (2012) further argues: "A constructivist approach holds that moral propositions are right or justified when they are consistent with acceptable moral principles, and moral principles are acceptable when they are the product of an appropriately designed decision procedure” (p. 230).

Using Kaufmann's logic, teachers and students build their understandings of values based on their previously acquired values and what is deemed to be 'acceptable' in society. With the importance of religion as a crucial foundation for a majority of the 
participants' values in Indonesia (see Chapter Five), an expanded understanding of values such as religious tolerance will only become acceptable as long as it is in line with prior understandings of religious tolerance established by the underlying Islamic theological framework. Hence the development or progression of these values is dependent on the progression of religion itself. Having notions of religious values that are conservative in nature may produce an individual's sense of values that are conservative and restrained. In examining Islam and citizenship, Pohl (2011) contends that a theological framework is needed as a basis of which "ideas and principles of tolerance and pluralism could be discussed from within the Islamic tradition" (pg. 403). As Pohl sees this as essential to have religious individuals who tend to be exclusive in nature to agree upon values that are promotes inclusivity. This I assume can be extended to other religions as well.

As previously stated before, citizenship is a form of values and is used as a reference point, to guide individuals or groups of diverse identities to find a way to live together politically (Irving, 2007; Miller, 2000). Being heavily dependent on religion in defining values, the current form of religious citizenship may prove to be problematic for inter-religious relations if it becomes more exclusive. In essence I argue that although some the values have been further expanded and constructed through the participants personal or social experiences they is still thoroughly dependent on a theological framework. In the case of Indonesia, this appears to be an increasingly conservative Islamic response in recent years which remains the backdrop to the development of both religious and citizenship identities. The result, religious citizenship, which assumes a middle ground for religion and secular-citizenship, is hinged to greater extent toward religion. Through this, secular laws become subjected to a theological framework and thus producing a more exclusive form of religious citizenship and the values that comes with it. We can see this in how some Muslim teachers from Jakarta Madrasah High and Jakarta Public High expressed a more rigid form of religious tolerance that is limited to forbearance or social tolerance, justifying this by referencing the phrase lakum dinukum wa-liya dini (to you be your way and to me mine) from the Qur'an. However, one of the interesting findings of my research was that the majority of student participants revealed more open and progressive understanding of religious tolerance and also expressed this through their lived experiences, such as the formation of inter-religious friendships. This 
finding contradicts the large-scale survey which was discussed in Chapter One which appeared to indicate that few Indonesian youth had cross-cultural friendships and were, indeed, more conservative previous generations. Some suggest that the practices of citizenship are more powerful than the statements (Wood, 2013). This findings suggests a more hopeful future for Indonesia than some have imagined.

This concept of religious tolerance as defined by the dominant group (Muslims) has become the norm for most Indonesians and is even reflected in the national curriculum (see Chapter One). This limits the expansion of religious tolerance as it is dependent on a theological framework. This issue has raised concerns among some of the minority participants. For examples, as a minority Sukono (M, Protestant), a Christian education teacher from Jakarta National High, feels that religious tolerance in Indonesia is inadequate, marred with ambiguities and he calls for a clearer definition of what it means to be religiously tolerant. Through the secret box method, an anonymous student from Jakarta Public High questions the neutrality of the state in protecting the rights of minorities. Where she/he feels that the current version of religious tolerance often benefits the Muslims, this raises questions about the use of values deriving from the majority religion to address issues of inter-religious conflict. We can also see how this limited concept of religious tolerance has also proven to be severely inadequate in dealing with intra-religious issues such as between the majority Sunni Muslim population and the minority Shiah Muslims where often the majority Sunni Muslim is given the upper hand (see Chapter One). Although examples of feelings of discrimination amongst the participants were minimal in this study, what small number of reported examples of discrimination show is that minorities are dissatisfied with the state's lack of neutrality in dealing with religious issues. In the next section I will look at how this limited understanding of inter-religious relations has affected inter-religious education in Indonesia.

\subsection{Issues of Indonesia's inter-religious education}

As discussed in Chapter Three, the religious education curriculum in Indonesia applies a mono-religious model (Sterkens, 2001), where the aim of religious education is 
the internalisation of a particular religious tradition held by the students - i.e. a Muslim must study Islam, a Catholic must study Catholicism, a Hindu must study Hinduism and so on. What was surprising in this study, was that while all schools were encouraged to apply this model, most teachers also combined aspects of Knitter's fulfilment model of inter-religious dialogue. Through this model, teachers indicate that they believe that some forms of values and truth can also be found in other religions, yet salvation can only be found in one particular religion that has absolute superiority (Knitter, 2002). The expanded understandings of the curriculum's mono-religious model of teaching religion showed how teachers were using their significant authority as gatekeepers between the written curriculum and the implemented curriculum in the classroom (Sim, 2012). However the teachers also indicated that they did not see the need for direct dialogue as they often opted to merely use tolerance when confronted with religious diversity issues. Such for instance teachers with Islamic backgrounds chose to manage religious issues by using religious tolerance that is based on a passage from the Qur'an: lakum dinukum waliya dini (to you be your way, and to me mine) to justify their understandings on how inter-religious relations should be approached. Through this, teachers emphasized the understanding that the truth of their religion is non-negotiable and believe in tolerance as in a form of forbearance and letting others be, rather than direct engagement, was the answer in striving for a peaceful co-existence.

Students from all three schools provided a more diverse view on how interreligious relations should take place. Examining Knitter's model we can place them along the lines of the fulfilment model or the mutuality model. Unlike the teachers above, some students noted that there is not only one true faith. For example, Adhung (M, Muslim, 19yrs), from Jakarta Madrasah High, stated: "Even if I'm a Muslim, I often think that many other religions are nicer than us. We can't say which one is the best one. Which one is the correct one, Christian or Muslims?" This statement places his beliefs in the mutuality model (Knitter, 2002) and indicates a far less conservative views than even his own teachers.

In all schools there was a very real sense that religion or faith was valuable for the students, and that faith helped the students solve real-world problems. Although all students from all schools were taught that religions are different, and valid, these 
differences were seen as bridgeable. The students believed that there is common ground between religions, that people of different faiths must learn to live together peacefully and that dialogue and interaction are necessary to do this. The openness and progressiveness of the students from the Jakarta Madrasah High, negates Kymlicka (2001) and Miedema (2006) claims which suggested that religious schools are unlikely to be able to prepare students for encountering and managing religious diversity due to their homogeneity and lack of exposure towards religious diversity. The findings from the Jakarta Madrasah High also confirms Halstead and McLaughlin (2005) argument that there is no evidence to support that religious schools cannot teach students on how to live with differences and that religious schools can actually provide students with much needed inclusive values.

This difference between the teachers and students on how they view interreligious communications seems to rest on how they have been differently exposed towards religious diversity and how they view religion itself. We saw how the students from Jakarta Madrasah High responded to engaging religious tolerance in their daily lives by not only participating in dialogue but also engaging in inter-religious friendships. Jakarta Public High and Jakarta National High, as non-religious schools have teachers and students from various religious backgrounds and this necessitates daily active engagement with people of various backgrounds. Yet it must also be noted that the interreligious engagements can cause some minorities to feel discriminated by the student's peers, such as the case of Anonymous Student A from Jakarta Public High (see Chapter Six). These findings echo Hansen (2011) belief that inter-religious dialogue should go beyond dialogue. Hansen (2011) suggests that "exposure to religions and life stances is crucial for us to acquire knowledge and understanding of our fellow citizens values and beliefs, and that such knowledge and understanding is beneficial for the promotion of tolerance" (p.114).

These comments highlight the significance of religious education in a society such as Indonesia, and the potential it holds to be a valuable asset to pluralist living. Considering the fact that the Indonesian population is divided into several religious groups and that religion plays an important role in society, it seems necessary to maintain 
religious education within schools. Teachers from across three schools argued against the elimination of religious education within the schools, as it could lead students to pay less attention to their own religion and may result in the lack of moral values within the students, due to the purpose of religious education was seen to help construct the coming generation with the "normative identity/beliefs/values" of the religious community (Brelsford, 2003). However, the challenge remains in how religious and citizenship education is implemented within schools, and this once again, draws our attention to the role of teachers as gatekeepers (Sim, 2012). I propose four ways in which religious education could be enhanced in Indonesia, building on ideas from Zuhdi (2005), Jackson (2004) and Hefner (2013).

First, I suggest that more dialogical and pluralistic forms of teaching could greatly enhance students' ability to deal with religious difference. While we can saw that teachers and students across the three schools mutually agreed on the purpose of religious education as a method to inculcate moral values, this research shows that the current religious education did little to expose students to religious diversity thus limiting the chances of an inter-religious dialogue. Seeing this problem, the purpose of religious education in non-religious schools should be directed toward students' understanding of different religious beliefs and traditions. Jackson (2004) and Zuhdi (2005) assert that with the increasingly pluralistic and secular nature of societies, the purpose of religious education must be shifted from merely teaching students of specific religious concepts to introducing students to various beliefs and cultures in order for them to have a better appreciation of diversity. One example of this may result in actively engaging in healthy inter-religious dialogue when confronted with issues rather than holding back for the sake of tolerance.

Second, in light of fears of religious relativism held by some of the teachers and students from the Jakarta Madrasah High and Jakarta Public High, it would prove an enormous challenge to shift religious education (or perhaps even citizenship education) in Indonesia from the mere encouragement and preservation of the religious tradition of each student and constant usage of religious tolerance in a way of mere forbearance, to a deep understanding and acceptance of the different religious beliefs. On this rationale, 
there needs to be an expansion of religious education in Indonesia, which not only preserves the religion of its adherents but also employs inter-religious education by exposing the students towards difference and by having them engage actively and respectfully with other individuals of different backgrounds.

Third, religious citizenship needs to be understood as a complex and dynamic reality. Although individuals may be identified as a religious individual, or part of a religious community and a citizen of a nation, this does not mean that they are static or constantly changing but instead maintains a fairly similar set of identities that are dependent on the social context (Ross, 2007). The main challenge would be to educate of each of these individuals to understand and accept that the identity of their religious citizenship may emerge and develop from several sources, and that it may be composed of multiple memberships and different identities (Burke \& Stets, 2009). The question now lies in the state; will Indonesia provide a clearer and more robust framework in which to answer to the growing Islamic conservatism? In creating the best conditions for this religious citizen identity to emerge without too many problems in the Indonesia of tomorrow, will the state understand the needs and requirements of the minorities as well by providing a more inclusive religious education that goes beyond tolerance and forbearance?

Finally, among the components presented here, the religious individuals and the more secular individuals are interwoven with one another, forming complex identities, and certainly do not reveal only religion within the individual's self-identity, but as a combination of fluid parameters. It is the task of the individual to manage the multiple sources of identity, which may help the individual, construct him/her-self. It is however the responsibility of the state to offer citizens a more progressive and open inter-religious education in order to help citizens construct a more tolerant self-identity. Importantly, citizens must not only come to terms with religious citizenship, which was developed under the auspices of the state, but also to realize the significant possibility that could arise through the intermingling of religious values and secular values which come from interactions within the society. As Osler and Starkey (2005) argue, citizenship is not only composed of a legal status defined by a group of laws and responsibilities but also by an 
identity and its expression within the political community. This offers a new way of dealing with the demands of active yet respectful inter-religious dialogue and finding common ground that is acceptable for both parties. In return, this may promote a more inclusive citizenship that is more readily situated for all groups regardless of their religion as citizenship is based on the feeling of belonging to a community and the desire to share aspirations and beliefs with other people. Through a more open and inclusive citizenship, every citizen may develop a greater sense of belonging to Indonesia and may reduce the discrimination that is suffered by minorities within the Indonesian society.

\subsection{Chapter summary}

In this chapter I have examined key findings from this research which suggest that the implementation of the religious and citizenship education curriculum by teachers largely applies a similar mono-religious model to that of the National Curriculum. However, there were a number of instances which suggested that teachers employed a mutuality model and this was found across both Muslim and Protestant teachers. Moreover, the data from some students suggested that they had more inclusive understandings of religious tolerance than their own teachers, and that some 'lived' their citizenship through daily practices of inter-religious interactions. Both of these findings point to ways that individuals in Indonesia are findings small ways to meet the challenges of living in a diverse and religiously pluralistic society. While this suggests more hopeful findings than one may expect in Indonesia today, my research has also identified a number of tensions in the current religious and citizenship education mode. With this in mind, I concluded this chapter by suggesting a number of strategies in order to further progress a more inclusive religious education as suggested by Zuhdi (2005) and Jackson (2004).

The final chapter draws conclusions from this study, looking at how it has contributed towards insights into the issues of citizenship, religion and religious tolerance in secondary schools, as well as other wider implications of this work. It also considers how this study can be applied in Indonesia and further afield. 


\section{CHAPTER 8: CONCLUSION}

\subsection{Chapter introduction}

The aim of this research was to explore Indonesia's secondary school teachers' and students' perceptions towards citizenship, identity and religious tolerance. I contended in the first chapter that this was an important area for research due to the recent interreligious issues occurring within Indonesia. These sectarian problems are in part due to the growing Islamic conservatism in Indonesia which has caused citizens to re-examine inter-religious relations and how to address those challenges. The citizenship and religious education curricula have become an important way to approach religious tolerance, and this research has examined how religious tolerance is defined and carried out. This chapter revisits the research questions in light of the findings, from which I draw several conclusions.

\subsection{Revisiting the research questions}

This research was underpinned by two research questions:

- RQ 1: what are the perceptions of secondary schools teachers' and students' towards religion, citizenship and identity?

- RQ 2: what are the perceptions of teachers and students towards religious tolerance?

My first research question asked, what are the perceptions of secondary schools teachers' and students' towards religion, citizenship and identity? The findings in Chapter Five showed that most student and teacher participants had multiple identities and most saw that their main identity was their national identity. A majority of the teacher participants elaborated the flexibility of their identities, which may surface dependent on their environment. Most of the student participants however demonstrated that they had variety 
of which they saw as their main identities either a national identity, religious identity or their cultural identity. Not all student participants insisted that their primary identity was their national identity. However, in contrast with the teachers, some student participants have expressed more of a cultural or proximity related identity such as the city they are currently living in at the moment.

Most teachers and students agreed in having religious education within schools varied across and within schools, as many saw it as a necessity not only for learning religion itself but also moral values. However although most participants showed an understanding of the need for religion as a foundation for their moral values, a small number of the participants saw that moral values may derive from other sources such as laws or the constitution. Most of the teachers' and students' participants have showed the importance of religion within the schools either reflected by the religious facilities within the schools or the attitudes of the teachers and students towards religion. Teachers and students both affirmed the need to study religion as an intellectual knowledge per se, but also as a moral guide in living life. How the teachers and students construct their identities and their sense of citizenship is grounded by their personal views of their religion. This has resulted in an entwinement of the religious values and the citizenship values of the teachers and the students, producing in as religious citizenship (Hudson, 2003; Miedema, 2006; Parker \& Hoon, 2013)

My second research question asked what are the perceptions of teachers and students towards religious tolerance? Some the teachers participants suggested a more conservative view of religious tolerance, merely defining religious tolerance as forbearance. Some teachers with an Islamic background showed that they base their understandings from their theological framework. However, while the curriculum encouraged a mono-religious approach some teachers also expanded the notion of religious tolerance toward a more inclusive understanding through their own experiences in inter-religious relations. Similarly, a majority of the students defined religious tolerance through a more open understanding. Findings suggested that students have not merely imitated on their teacher's definition of religious tolerance but have also personally constructed their own definitions of it as well. This also highlights that the 
social constructivist theoretical paradigm and constructionist methodological approach taken in this study was a fitting one, as it shows teachers and students build upon their own understandings of how they perceived religious tolerance through their own experiences and observations and didn't simply reproduce the teacher's or the curriculum's definition of religious tolerance.

With the usage a qualitative research method, the research also showed a much more complex understanding of how the teachers and students perceived their sense of identity, citizenship and religious tolerance. While findings suggested that there are some lingering tensions between the majority Muslim population and the minority Christians and some teachers and students provided a more conservative understanding of religious tolerance, the findings also showed a more hopeful prospect of Indonesia's youth in embracing a more open and inclusive inter-religious relations. In sum, what this research paints is a complex picture of Indonesia's inter-religious relations, as there are some elements of hope seen within Indonesia's youth and some challenges seen in the occasional conservative understandings of inter-religious relations. It is this that the Indonesian society has yet come to grips with.

\subsection{Implication for stakeholders}

One aim of my research was that the findings might inform future development programmes in managing inter-religious relations. As religious conservatism in religious diverse Indonesia is on the rise (Hefner, 2013; PewResearch, 2013; Pohl, 2011) there is a critical need for a more inclusive approach towards inter-religious relations other than just mere tolerance. This has yet to be seen in Indonesia's curriculum. While this study is small in scale and its findings highlight the conservative outlook of managing interreligious relations yet it also provides some hopeful findings that suggests more inclusive perceptions from both the teachers and students in dealing with inter-religious relations, as most of the students in this study were found to be less intolerant than the 2010-2012 LAKIP survey suggested (see Chapter One). In addition practices of citizenship were hopeful as both teachers and students in particular have personally engaged in inter- 
religious relations, all resulting in social interactions that enabled more inclusive outcomes. However I believe that it is the state's responsibility in providing a more inclusive approach to manage inter-religious relations within schools remembering not only the increase of conservatism but also that young Muslims are both targets and agents Indonesia’s Islamic resurgence (Parker \& Nilan, 2013).

\subsection{Limitations of study and further research}

My research has looked at a small number of case study schools and so the findings are not generalisable. Due to the time limitations of a Master's thesis, I have provided insights into religious citizenship and inter-religious education in only three secondary schools in Indonesia, specifically in Jakarta. However, I believe that the area of religious citizenship and inter-religious education offers huge potential for future research and so I have suggested possible areas that I think would be valuable to pursue in future research in the area of religious citizenship and inter-religious education in Indonesia's secondary schools:

1. There has been very little in-depth research between Indonesia's citizenship, religion and education and how it has affected inclusive values such as interreligious relations. The very few that have be done are qualitative in nature (see Parker (2008)) thus a larger quantitative research is needed in order to understand the full extent of educating religion, citizenship and inter-religious relations. In addition to this, due to the research being a small-scale study, the research therefore is not generalisable yet it provides additional information towards the dearth of studies within this area.

2. My research has looked at teachers' and students' perceptions towards citizenship, religion and inter-religious relations at three case study schools. I believe that a study looking at the practices of the teachers in carrying out their notions on interreligious relations would provide in-depth and constructive information regarding the implementation of inclusive citizenship values in Indonesia's secondary schools. This could be useful for secondary schools currently struggling develop 
pedagogies that support a more inclusive understanding of inter-religious relations.

3. Finally, my research looked at the perceptions toward citizenship, religion and inter-religious relations of teachers and students. The extent to how religious education or citizenship education has affected student's perceptions of interreligious relations cannot be fully verified as caused by education alone as findings in my research suggest external factors outside the schools have affected the students' perceptions in regards to this issue. In addition to this further research is needed on both urban and rural teachers and youth, in particular their religious identities as the social factors vary considerably between areas in Indonesia. Thus this will affect the teachers' and students' perceptions on citizenship, religion and inter-religious relations.

\subsection{Final remarks}

While at the beginning I was sceptical of the perceptions of religious tolerance I entered this research with reflexivity, open to critical debate that I was aware would add to my insight into the current state of inter-religious relations in Indonesia. Although my research has given some hope of a more inclusive future for youths in Indonesia, I must also accept that this hope is fragile, as Indonesia still faces growing religious conservatism within its' society and lingering tensions between its religious groups. Yet I remain optimistic and remain a strong advocate of an expanded notion of inter-religious dialogue that is not merely confined to inter-religious forbearance. I have no doubt as Indonesia progresses, the society will see the limitations of its' mere inter-religious forbearance and will strive to go beyond that. 


\section{REFERENCES}

Adams, P. (2006). Exploring social constructivism: theories and practicalities. Education 3-13, 34(3), 243-257. doi: 10.1080/03004270600898893

Al Sadi, F. H., \& Basit, T. N. (2013). Religious tolerance in Oman: Addressing religious prejudice through educational intervention. British Educational Research Journal, 39(3), 447-472. doi: http://doi.wiley.com/10.1080/01411926.2011.652071

Ali, H. M. (1974). Religion and development in Indonesia. International Review of Mission, 63(251), 400-416.

Anderson, B. (1992). Imagined Communities. New York: Verso.

Appiah, K. A. (2006). Cosmopolitanism: Ethics in a world of strangers. New York: W. W. Norton.

Apple, M. W. (2004). Ideology and curriculum. New York: RoutledgeFalmer.

Bagir, Z. A. (2008). Interfaith dialog and religious education. Paper presented at the 4th Asia-Europe Meeting (ASEM) Interfaith Dialogue, Amsterdam, Netherlands.

Bagir, Z. A. (2009). Shari'a in the secular state: Challenge or opportunity. Netherlands.

Banks, J. A. (2007). Democratic citizenship education in multicultural societies. In J. A. Banks (Ed.), Diversity and citizenship education: Global perspectives. San Francisco: Wiley.

Barbour, R. (2008). Doing focus groups. London: SAGE.

Baumann, G. (1999). The multicultural riddle: Rethinking national, ethnic, and religious Identities. New York: Routledge.

Berg, B. L., \& Lune, H. (2012). Qualitative research methods for the social sciences. Boston: Pearson Education, Limited. 
BPS. (2010). Penduduk Menurut Wilayah dan Agama yang Dianut. Sensus Penduduk 2010. 2010 ,

from http://sp2010.bps.go.id/index.php/site/tabel?tid=321\&wid=0

Brelsford, T. (2003). Editorial. Religious Education, 98(2), 135-138.

BSNP. (2006). Standar isi KTSP 2006. Jakarta: Badan Standar Nasional Pendidikan Retrieved from $\quad \underline{\text { http://bsnp-indonesia.org/id/wp- }}$ content/uploads/2009/06/01.-SMA-MA.zip.

Burke, P. J., \& Stets, J. E. (2009). Identity Theory. USA: Oxford University Press.

Burton, N., Brundrett, M., \& Jones, M. (2008). Doing your education research project: SAGE Publications.

CNN. (2005). Bali terrorist blasts kill at least 26. Retrieved January 5, 2014, from http://edition.cnn.com/2005/WORLD/asiapcf/10/01/bali.blasts/

Colbran, N. (2010). Realities and challenges in realising freedom of religion or belief in Indonesia. The International Journal of Human Rights, 14(5), 678-704. doi: $10.1080 / 13642980903155166$

Creswell, J. W. (2012). Qualitative inquiry and research design: Choosing among five approaches. Los Angeles: SAGE Publications.

Daniel, N. (1993). Islam and the west: The making of an image. Edinburgh: One World.

Dewey, J. (1916). Democracy and education: An introduction to the philosophy of education. New York: Macmillan.

Dikti. (2012). Sejarah perkembangan kurikulum Indonesia. http://pjipgsd.dikti.go.id/file.php/1/repository/dikti/Revisi Bahan Ajar Cet ak/BAC Pengkur SD/UNIT-4 PERKEMBANGAN KURIKULUM .pdf 
Dobbernack, J., \& Modood, T. (2012). Tolerance and cultural diversity in schools: Comparative Report. In M. Maussen \& V. Bader (Eds.), Accept Pluralism. Italy: European University Institute.

Esposito, N. (2001). From meaning to meaning: The influence of translation techniques on non-English focus group research. Qualitative Health Research, 11(4), 568579. doi: $10.1177 / 104973201129119217$

Gillespie, P. (2007). Current issues in Indonesian Islam: Analysing the 2005 council of Indonesian ulama fatwa n0.7 opposing pluralism, liberalism and secularism. Journal of Islamic studies, 18(2), 202-240.

Guardian. (2004). Australian embassy bomb kills nine. Retrieved January 6, 2014, from http://www.theguardian.com/world/2004/sep/09/indonesia.australia1

Guba, E., \& Lincoln, Y. (2001). Competing paradigms in qualitative research. In C. Conrad, J. G. Haworth \& L. Lattuca (Eds.), Qualitative research in higher education: Expanding perspectives (2nd ed., pp. 55-71). Boston: Pearson Custom Publishing.

Halstead, J. M., \& McLaughlin, T. (2005). Are faith schools divisive? In R. Gardner, J. Cairns \& D. Lawton (Eds.), Faith schools: Consensus or conflict? London and New York: Routledge and RoutledgeFalmer.

Hansen, O. H. B. (2011). Teaching tolerance in public education: organizing the exposure to religious and life-stance diversity. Religion \& Education, 38(2), 111-127. doi: $10.1080 / 15507394.2011 .579549$

Hassan, R. (2007). On being religious: Patterns of religious commitment in Muslim societies. The Muslim World, 97(3), 437-478.

Hayes, B. C., McAllister, I., \& Dowds, L. (2013). Integrated schooling and religious tolerance in Northern Ireland. Journal of Contemporary Religion, 28(1), 67-68. doi: http://www.tandfonline.com/doi/abs/10.1080/13537903.2013.750837 
Hefner, R. W. (2013). The Study of religious freedom in Indonesia. The Review of Faith \& International Affairs, 11(2), 18-27. doi: 10.1080/15570274.2013.808038

Hing, L. K. (1978). The Taman Siswa in postwar Indonesia. Indonesia(25), 41-59. doi: $10.2307 / 3350966$

Holstein, J. A., \& Gubrium, J. F. (2008). Handbook of constructionist research. New York: Guilford Press.

Hoyt, M. F. (2000). Some stories are better than others: Doing what works in brief therapy and managed care. Phladelphia: Brunner/Mazel.

HRW. (2013). In religion's name: Abuses against religious minorities in Indonesia. Jakarta: Human Rights Watch.

Hudson, W. (2003). Religious citizenship. Australian Journal of Politics and History, 49(3), 425-429.

Hung, D., Lim, S. H., \& Jamaludin, A. B. (2010). Social constructivism, projective identity, and learning: case study of nathan. Asia Pacific Education Review, 12(2), 161-171. doi: 10.1007/s12564-010-9116-y

Huntington, S. P. (1996). The clash of civilizations and the remaking of world order. New York: Simon \& Schuster.

Irving, H. (2007). Citizenship, statehood and allegiance. In L. Cardinal \& N. Brown (Eds.), Managing diversity: Practices of citizenship. Otawa: University of Ottawa Press.

Jackson, R. (2004). Rethinking religious education and plurality. New York: RoutledgeFalmer.

Jackson, R. (2007). European institutions and the contribution of studies of religious diversity. In R. Jackson, S. Miedema, W. Weisse \& J.-P. Willaime (Eds.), Religion 
and edu-cation in Europe: Developments, contexts and debates. Munster: Waxmann.

Johnson, B., \& Christensen, L. (2010). Educational research: Quantitative, qualitative, and mixed approaches. Los Angeles: SAGE Publications.

Jones, E., \& Kay, M. (1992). Instrumentation in cross-culture research. Nursing Research, 41(3), 186-188.

JP. (2012). Moderate Islam on the brink against radicals. Retrieved September 14, 2013, from http://www.thejakartapost.com/news/2012/06/25/moderate-islambrink-against-radicals.html

JP. (2013). Ministries reaffirm curbs on Ahmadiyah. Retrieved July 11, 2013, from http://www.thejakartapost.com/news/2013/05/31/ministries-reaffirmcurbs-ahmadiyah.html

Kaufman, A. (2012). Rawls and Kantian constructivism. Kantian Review, 17(02), 227256. doi: $10.1017 / \mathrm{s} 1369415412000040$

Kelman, H. C. (2001). The role of national identity in conflict resolution: Experiences from Israeli-Palestinian problem-solving workshops In R.D. Ashmore, L. Jussim, $\& D$. Wilder (Eds.), Social identity, intergroup conflict, and conflict reduction (pp. 187-212). Oxford and New York: Oxford University Press.

Kemenag. (2008). Peraturan menteri agama Republik Indonesia nomor 2 tahun 2008 tentang standar kompetensi lulusan dan standar isi pendidikan agama Islam dan bahasa Arab di madrasah. Jakarta: Kementerian Agama Retrieved from http://www.google.co.nz/url?sa=t\&rct=j\&q=\&esrc=s\&source=web\&cd=3\&ca $\mathrm{d}=$ rja\&ved=0CDkQFjAC\&url=http\%3A\%2F\%2Fvionardi.files.wordpress.com \%2F2011\%2F10\%2Fpermenag-nomer-2-tahun-2008.doc\&ei=0vj Utrej iAeExYFQ\&usg=AFQjCNHFzqqwbBjpcfRGILJaSbO33iXi4Q\&sig2=B0nUsq cKZ1cDLQMst-BQdA\&bvm=bv.61535280,d.aGc. 
Kemenag. (2009). Deskriptif statistik pendidikan madrasah. Jakarta: Kementerian $\begin{array}{lll}\text { Agama } & \text { Retrieved }\end{array}$ http://pendis.kemenag.go.id/file/dokumen/deskripmadrasah.pdf.

Kemendikbud. (2003). Undang-undang Republik Indonesia no. 20 tahun 2003 tentang sistem pendidikan nasional. Jakarta: Kementerian Pendidikan dan Kebudayaan.

Kerr, D. (1999). Citizenship education in the curriculum: An international review. The School Field, 10(3/4), 5-32.

Kipp, Smith, R., \& Rodgers, S. (1987). Introduction: Indonesian religions in society. In Kipp \& S. Rodgers (Eds.), Indonesian religions in transition (pp. 1-34). Tucson.

Knitter, P. F. (2002). Introducing theologies of religion. New York: Orbis.

Korostelina, K. V. (2007). Social identity and conflict: Structures, dynamics, and implications. New York: Palgrave Macmillan.

Kuipers, J. C. (2011). Religion and worldview. In W. H. Frederick \& R. L. Worden (Eds.), Indonesia a country study (pp. 118-126). Washington D. C.: Federal Research Division Library of Congress.

Kymlicka, W. (2001). Politics in the vernacular : nationalism, multiculturalism, and citizenship. New York: Oxford University Press.

Leirvik, O. (2004). Religious education, communal identity and national politics in the Muslim world. British Journal of Religious Education, 26(3), 223-236.

Levinson, B. A., \& Sutton, M. (2008). Civic education reform for democracy: U.S. models in Mexico and Indonesia. In D. Stevick \& B. A. Levinson (Eds.), Advancing democracy through education?: U.S. influence abroad and domestic practices (pp. 129-158). Scottsdale: IAP-Information Age Pub. Incorporated.

Locke, J. (1983). A letter concerning toleration. Indianapolis: Hackett. 
LSI. (2006). Radikalisme Islam dan sikap publik Indonesia. Jakarta: Lembaga Survey Indonesia.

Lydersen, K. M. (2011). Democratic citizenship education in Indonesia post-Suharto: Political indoctrination or critical democratization? (MA), University of Oslo, Oslo.

Maarif, A. S. (2008). Islam and democratization in Indonesia. In W. Hudson \& A. Azra (Eds.), Islam beyond conflict: Indonesian Islam and western political theory. Burlington, USA: Ashgate Publishing Company.

May, J. D. A. (2006). Can tolerance be taught? Steps towards inter-religious education. Journal of Religious Education, 54(4), 11-15.

Miedema, S. (2006). Educating for religious citizenship: Religious education as identity formation. In G. D. M. de Souza, K. Engebretson, R. Jackson, A. McGrady (Ed.), International handbook of the religious, moral and spiritual dimensions in education (pp. 967-976). The Netherlands: Springer.

Miller, D. (2000). Citizenship and national identity. San Francisco: Wiley.

Mitchell, K., \& Parker, W. C. (2008). I pledge allegiance to . . flexible citizenship and shifting scales of belonging. Teachers College Record, 110(4), 775-804.

Mortimer, R. (1974). Indonesian communism under Soekarno. Ithaca, NY: Cornell University Press.

Muldoon, R., Borgida, M., \& Cuffaro, M. (2011). The conditions of tolerance. Politics, Philosophy \& Economics, 11(3), 322-344. doi: 10.1177/1470594x11417115

N.I.U. (n.d). Principles supporting qualitative research. Retrieved September 16, 2013, from

http://www.cedu.niu.edu/ sorensen/502/powerpoint/topicD/qlnotes.htm 
Newman, J. (1982). Foundations of religious tolerance. Toronto: University of Toronto Press.

Nord, W. A. (1995). Religion \& American Education: Rethinking a National Dilemma: University of North Carolina Press.

Oberdiek, H. (2001). Tolerance: Between forbearance and acceptance. Lanham: Rowman \& Littlefield Publishers.

Osler, A., \& Starkey, H. (2005). Changing Citizenship: Democracy And Inclusion in Education. New York: Open University Press.

Parker, L. (2008). Introduction: Islamic Education in Indonesia. RIMA: Review of Indonesian and Malaysian Affairs, 42(1), 1-8.

Parker, L., \& Hoon, C.-Y. (2013). Secularity, Religion and the Possibilities for Religious Citizenship. Asian Journal of Social Science, 41(2), 150-174. doi: $10.1163 / 15685314-12341296$

Parker, L., \& Nilan, P. (2013). Adolescents in contemporary Indonesia. London ; New York: Routledge.

Patton, M. Q. (2002). Qualitative research \& evaluation methods. Thousand Oaks: SAGE Publications.

PewResearch. (2013). PewResearch religion \& public life project. Retrieved July, 15, 2013, from http://www.pewforum.org/2013/04/30/the-worlds-muslimsreligion-politics-society-beliefs-about-sharia/

Pohl, F. (2011). Negotiating religious and national identities in contemporary Indonesian Islamic education. Cross Currents, 61(3), 399-414.

Punch, S. (2002). Interviewing strategies with young people: The 'secret box', stimulus material and task-based activities. Children and Society, 16(1), 45-46. 
Raihani. (2011). A whole-school approach: A proposal for education for tolerance in Indonesia. Theory and Research in Education, 9(1), 23-39. doi: $10.1177 / 1477878510394806$

Republika. (2013). MK bubarkan RSBI. Retrieved 3 March, 2013, from http://www.republika.co.id/berita/nasional/hukum/13/01/08/mgat12-mkbubarkan-rsbi

Ropi, I. (2012). The politics of regulating religion: State, civil society and the quest for religious freedom in modern Indonesia. (Ph.D Ph.D), Australian National University, Canberra.

Ross, A. (2007). Multiple identities and education for active citizenship. British Journal of Educational Studies, 55(3), 286-303.

Roy, O. (2004). Globalized Islam: The search for a new ummah. London: Columbia University Press.

Samsuri. (2012). Kilas balik pendidikan pancasila dan kewarganegaraan: Perspektif politik kebijakan pendidikan nasional di Indonesia. Paper presented at the Focus group discussion materi ajar dan metodologi pembelajaran pendidkan pancasila dan kewarganegaraan kelas IV-VI sekolah dasar/madrasah ibtidaiyah, Solo, Indonesia.

Sen, A. (2007). Identity and violence: The illusion of destiny. New York: Penguin.

Setara. (2012). Laporan kebebasan beragama 2012. In S. Institute (Ed.). Jakarta: Setara Institute.

Shor, I. (1992). Empowering education: Critical teaching for social change. Chicago: University of Chicago Press.

Sim, J. B.-Y. (2012). Simple ideological "dupes" of national governments? Teacher agency and citizenship education in Singapore. In K. J. Kennedy, W. O. Lee \& D. 
L. Grossman (Eds.), Citizenship Pedagogies in Asia and the Pacific. Hong Kong: Springer.

Splitter, L. (2011). Identity, citizenship and moral education. Educational Philosophy and Theory, 43(5), 484-505. doi: 10.1111/j.1469-5812.2009.00626.x

Sterkens, C. (2001). Interreligious learning: The problem of interreligious dialogue in primary education. Boston: Brill.

Sudjatmiko, I. G. (2008). Communal conflict, state, failure and peacebuilding: the case of Ambon, Indonesia. Conflict Management, Peace Economics and development, 7(1), 349-363.

Sutinen, A. (2007). Constructivism and education: education as an interpretative transformational process. Studies in Philosophy and Education, 27(1), 1-14. doi: 10.1007/s11217-007-9043-5

TWI. (2012). Laporan akhir tahun kebebesan beragama dan intoleransi 2012. Indonesia: The Wahid Institute.

USCIRF. (2013). United States commision on international religious freedom: Annual report 2013. Washington, DC: USCIRF.

Weithman, P. J. (2002). Religion and the obligations of citizenship. Cambridge: Cambridge University Press.

Wood, B. E. (2013). Young people's emotional geographies of citizenship participation: Spatial and relational insights. Emotion, Space and Society, 9(2013), 50-58.

Zuhdi, M. (2005). Religious education in Indonesian schools. Paper presented at the Redesigning pedagogy: Research, policy and practice, Singapore.

Zuhdi, M. (2006). Modernization of Indonesian Islamic schools' curricula, 1945-2003. International Journal of Inclusive Education, 10(4-5), 415-427. doi: 10.1080/13603110500430765 


\section{APPENDICES}

\section{Appendix A: Information sheet for schools}

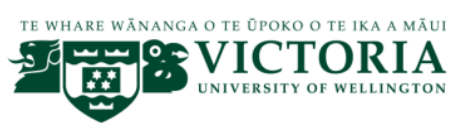

Date......

Dear [Principal]

Title of research: Teachers' and Students' Perceptions Towards Religious Pluralism and Tolerance in the Religious Education and Civics Education Curricula In Indonesia

Researcher: Ben K. C. Laksana, School of Education Policy and Implementation, Faculty of Education, Victoria University of Wellington, New Zealand

\section{RESEARCH INFORMATION SHEET: SCHOOL PRINCIPALS}

I am a post-graduate student at the School of Education Policy and Implementation, Faculty of Education, Victoria University of Wellington, New Zealand with an interest in the implementation of the religious education and civics education curricula and how these curricula shape and are shaped by people's identities. The intention of this research is to investigate how religious pluralism and tolerance articulated in the national curriculum have been reflected in the perceptions of teachers and students. My Master's research is supervised by Dr. Bronwyn Wood, in the School of Education, Policy and Implementation. The research has been approved by the Faculty of Education Human Ethics Sub-committee under delegated authority from the Victoria University Human Ethics Committee (no.19857).

This research intends to shed light on how teachers are enacting the curricula requirements toward promoting more tolerant and inclusive values in Indonesian society. This research could also provide insights into our understandings of young people's citizenship dispositions and identities and how they understand religious tolerance and pluralism.

What is involved with the research?

If you are happy for me to proceed with this research in your school, the religious education teachers, civics education teachers and students involved in the project are of year 12 will be invited to be involved into this research. With their permission, I will also be inviting their students (Year 12) in one class to participate. Teachers or students do not have to be part of my research and their participation will be voluntary.

Teachers will be invited to participate in an individual interview. These interviews would take place at school and will be conducted during normal school hours (e.g. department meeting or professional learning time) and will last approximately forty five minutes each. 
I will also invite students to participate in a focus group interview and see how they perceive issues of religious tolerance and pluralism that will last approximately forty five minutes each. I will make sure that students are comfortable during these focus groups to talk about religion and identity by ensuring they are in groups with similarly affiliated religious peers.

I am happy to answer any questions about this research at a meeting I will schedule with you before the research proceeds.

Victoria University requires that ethics approval for research involving human participants is obtained. If you would like to accept the invitation of your school to participate in this research, could you please sign the form below and return it to me at the time of our focus group interview or email your consent to me prior to the interview.

\section{Privacy and confidentiality}

The names of all teachers and students will remain confidential to the researcher, and teachers will be given pseudonyms in any publications or public dissemination of data.

All data collected will be stored in a locked filing cabinet and all electronic information will be password protected. Information from this research will be submitted for publication in academic journals and conferences. All data will be destroyed five years after completion of the research.

I will send teachers and students a summary of the initial data analysis to allow them to reflect upon this, and, if necessary, add to and amend this analysis. I will be happy to send you this information as well (please indicate on the consent form if you wish for this to happen).

Please feel free to contact me with any questions that you may have regarding the research by email (ben.laksana@vuw.ac.nz) or telephone.

Warm regards,

Ben K. C. Laksana

Contact details:

Ben K. C. Laksana [supplied]

Supervisor, Dr. Bronwyn Wood [supplied]

Chair of VUW Ethics Committee, Dr. Allison Kirkman [supplied] 


\section{Appendix B: Consent to participation in research for schools}

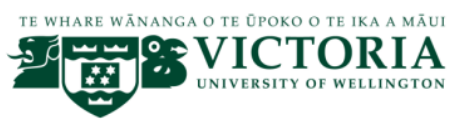

\section{CONSENT TO PARTICIPATION IN RESEARCH: PRINCIPAL}

Title of research: Teachers' and Students' Perceptions Towards Religious Pluralism and

Tolerance in the Religious Education and Civics Education Curricula In Indonesia

Researcher: Ben K. C. Laksana, School of Education Policy and Implementation, Faculty of Education, Victoria University of Wellington, New Zealand

- I have been given and understand the information about this research project.

- I have had an opportunity to ask questions and have them answered to my satisfaction.

- I understand that [name of school] will not be named in research publications; I understand that names of teachers and students will be altered so they are not identifiable and that teachers will have a chance to give input on this process.

- I give consent for Ben K. C. Laksana to invite teachers to participate in his research project.

- I would like to receive feedback on the findings of this research.

\begin{tabular}{|ll|}
\hline Signed: & Date: \\
\hline Name: & Email:
\end{tabular}

School:

Please feel free to contact me with any questions that you may have regarding the research. 


\section{Appendix C: Information sheet for teachers}

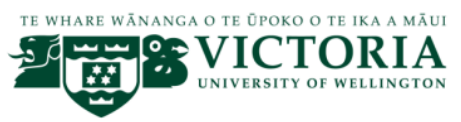

Date......

Dear [teacher]

Title of research: Teachers' and Students' Perceptions Towards Religious Pluralism and Tolerance in the Religious Education and Civics Education Curricula In Indonesia

Researcher: Ben K. C. Laksana, School of Education Policy and Implementation, Faculty of Education, Victoria University of Wellington, New Zealand

\section{RESEARCH INFORMATION SHEET: TEACHERS}

I am a post-graduate student at the School of Education Policy and Implementation, Faculty of Education, Victoria University of Wellington, New Zealand with an interest in the implementation of the religious education and civics education curricula and how these curricula shape and are shaped by people's identities. The intention of this research is to investigate how religious pluralism and tolerance articulated in the national curriculum have been reflected in the perceptions of teachers and students. My Master's research is supervised by Dr Bronwyn Wood, in the School of Education, Policy and Implementation. The research has been approved by the Faculty of Education Human Ethics Sub-committee under delegated authority from the Victoria University Human Ethics Committee (no.19857).

This research intends to shed light on how teachers are enacting the curricula requirements toward promoting more tolerant and inclusive values in Indonesian society. This research could also provide insights into our understandings of young people's citizenship dispositions

\section{What is involved with the research?}

I would like to invite you to participate in an individual interview about your perceptions and practices toward the teaching of inclusiveness. You do not have to be part of my research and your participation is voluntary. Interviews would take place at school and will be conducted during normal school hours (e.g. department meeting or professional learning time) and will last approximately forty five minutes each. If you have any questions regarding this research, I would be happy to answer any questions at an optional meeting which we can scheduled prior to the interview. I am also interested in your curriculum planning documents and, if possible, I would like to take copies of these for my research.

Victoria University requires that ethics approval for research involving human participants is obtained. If you would like to accept the invitation to participate in this research, could you 
please sign the form below and return it to me at the time of our interview or email your consent to me prior to the interview.

\section{Example of interview questions}

1. To what extent is the importance of religion in the national curriculum?

2. Do you agree/disagree with the curriculum's stance towards religious pluralism and tolerance? Why?

3. In regards to the national curriculum, how would you define religious tolerance?

4. How important are the ideas of religious pluralism and tolerance to your identity as an Indonesian? How do these values effect your teaching?

5. What identity would you affiliate with most closely?

\section{Privacy and confidentiality}

The names of all teachers and students will remain confidential to the researcher, and teachers will be given pseudonyms in any publications or public dissemination of data.

All data collected will be stored in a locked filing cabinet and all electronic information will be password protected. Information from this research will be submitted for publication in academic journals and conferences. All data will be destroyed five years after completion of the research.

I will send teachers a copy of the initial data analysis so that teachers may provide clarification and feedback. You may indicate your preference on the consent form.

Please feel free to contact me with any questions that you may have regarding the research by email (ben.laksana@vuw.ac.nz) or telephone.

Thank you in anticipation of your contribution to this study.

Kind regards,

Ben K. C. Laksana

Contact details:

Ben K. C. Laksana [supplied]

Supervisor, Dr. Bronwyn Wood [supplied]

Chair of VUW Ethics Committee, Dr. Allison Kirkman [supplied] 


\section{Appendix D: Consent to participation in research for teachers}

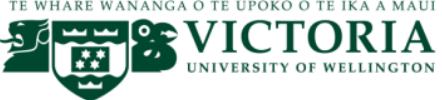

\section{CONSENT TO PARTICIPATION IN RESEARCH: TEACHERS}

Title of research: Teachers' and Students' Perceptions Towards Religious Pluralism and Tolerance in the Religious Education and Civics Education Curricula In Indonesia

Researcher: Ben K. C. Laksana, School of Education Policy and Implementation, Faculty of Education, Victoria University of Wellington, New Zealand

- I have been given and understand the information about this research project.

- I have had an opportunity to ask questions and have them answered to my satisfaction.

- I consent to taking part in an interview and to the interview being audio recorded and transcribed.

- I understand that any information I provide will be kept confidential to the researcher, the research assistant/transcribe and that the published results will not use my name, and that no opinions will be attributed to me in any way that will identify me.

- I understand that I may withdraw myself (or any information I have provided) from this project (before data analysis is complete, approx. by October 2013) without having to give reasons or without penalty of any sort.

- I understand that [name of school] will not be named in research publications; I understand that my real name will not be used and I will have an opportunity to discuss if I wish to have other identifying details altered.

- I understand that the tape recording of the interview will be electronically wiped at the end of the project unless I indicate that I would like them returned to me.

- I would like my interview electronically wiped at the conclusion of the research.

- I would like to receive feedback on the findings of this research (if yes, please provide email below)

\begin{tabular}{|ll|}
\hline Signed: & Date: \\
\hline Name: & Email: \\
\hline School: & \\
\hline
\end{tabular}

Please feel free to contact me with any questions that you may have regarding the research. 


\section{Appendix E: Information sheet for students}

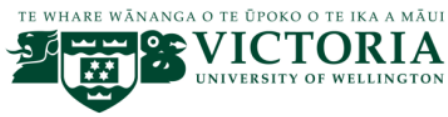

Date......

Dear [Students]

Title of research: Teachers' and Students' Perceptions Towards Religious Pluralism and Tolerance in the Religious Education and Civics Education Curricula In Indonesia

Researcher: Ben K. C. Laksana, School of Education Policy and Implementation, Faculty of Education, Victoria University of Wellington, New Zealand

\section{RESEARCH INFORMATION SHEET: STUDENTS}

Hi there,

I am a post-graduate student at the School of Education Policy and Implementation, Faculty of Education, Victoria University of Wellington, New Zealand with an interest in the implementation of the religious education and civics education and also in young people's understandings of citizenship values. The intention of this research is to understand the teachers' and students' perceptions towards citizenship values specifically towards pluralism and to explore how teachers' and students' perceive their identities and how this has shaped their perceptions. The research has been approved by the Faculty of Education Human Ethics Sub-committee under delegated authority from the Victoria University Human Ethics Committee (no.19857).

\section{What is involved with the research?}

Since religious education and civics education is compulsory in Indonesia, I want to understand how you perceive issues of citizenship values specifically religious tolerance and pluralism and also how this shapes your personal identity. I will talk to you about this with a group of other students in a focus group interview (which consists of 6-10 students) which will last approximately forty five minutes each.

\section{Example of interview questions}

1. How important is religion to you in your education?

2. What do you see as the purpose of religious education? Civics education?

3. The Indonesian curriculum states that teaching tolerance and inclusion is an essential part of the curriculum for students - how do you see this played out in your religious education class? In your civics education class?

4. How would you define religious tolerance? 
5. What identity would you affiliate with most closely?

I am happy to answer any questions about this research at a meeting I will schedule with you before the research proceeds.

Victoria University requires that ethics approval for research involving human participants is obtained. If you would like to accept the invitation to participate in this research, could you please sign the form below and return it to me at the time of our focus group interview or email your consent to me prior to the interview. If you are under 16, you will also need your parent/caregiver's signature for their approval to be involved.

\section{Privacy and confidentiality}

I won't share your real name with anyone else. Instead, if you choose to be involved, I will give you a 'code' name to disguise your identity and I will not name your school. Also since this will be a focus group interview, you will need to keep the responses of your friends confidential. You

will get a chance to check what I have collected and analysed and have an opportunity to give me some more ideas about the research at this stage. You can choose to pull out of the research at any time up before the data analysis.

The information from this research will be used to write up reports that can be read by teachers and lecturers, and presented at conferences. All data collected will be stored in a locked filing cabinet and all electronic information will be password protected so other people can't get their hands on it who we didn't intend to see it.

Please feel free to contact me with any questions that you may have regarding the research by email (ben.laksana@vuw.ac.nz) or telephone.

Thank you in anticipation of your contribution to this study.

Kind regards,

Ben K. C. Laksana

Contact details:

Ben K. C. Laksana [supplied]

Supervisor, Dr. Bronwyn Wood [supplied]

Chair of VUW Ethics Committee, Dr. Allison Kirkman [supplied] 


\section{Appendix F: Consent to participation in research for students}

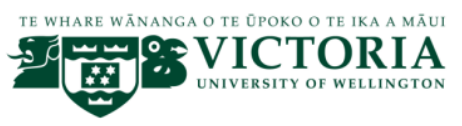

\section{CONSENT TO PARTICIPATION IN RESEARCH: STUDENTS}

Title of research: Teachers' and Students' Perceptions Towards Religious Pluralism and Tolerance in the Religious Education and Civics Education Curricula In Indonesia

Researcher: Ben K. C. Laksana, School of Education Policy and Implementation, Faculty of Education, Victoria University of Wellington, New Zealand

- I have been given and understand the information about this research project.

I have had an opportunity to ask questions and have them answered to my satisfaction.

- $\quad$ I understand that any information I provide will be kept confidential

to the researcher, the research assistant/transcribe and that the published results will not use my name, and that no opinions will be attributed to me in any way that will identify me.

- I understand that any information that my friends have provided during the focus group interview I will need to keep confidential.

- I understand that I may withdraw myself (or any information I have provided) from this project (before data analysis is complete, approx. by October 2013) without having to give reasons or without penalty of any sort.

- I understand that [name of school] will not be named in research publications; I understand that my real name will not be used and I will have an opportunity choose a 'code name' or have one allocated to me by the researcher.

- I I am happy for Ben to record me talking about my experience in the learning religious education and civics education.

- I would like my recordings electronically wiped at the conclusion of the research.

- I would like to receive feedback on the findings of this research.

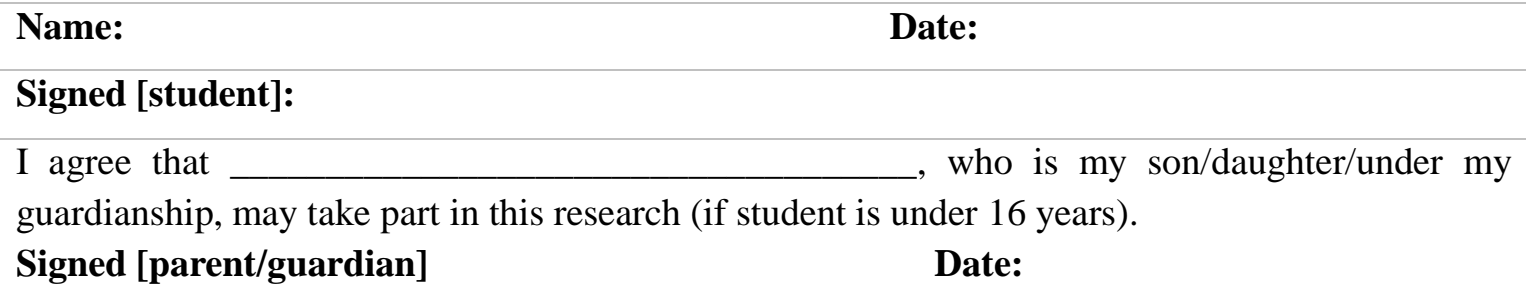

Please feel free to contact me with any questions that you may have regarding the research. 


\section{Appendix G: Demographic information}

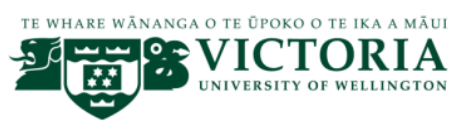

Collection of participant demographic information and questions for teacher interview and student focus group interview

A) Demographic information: Teacher

\begin{tabular}{|l|l|}
\hline Name: & \\
\hline Pseudonym: (you may choose or the & \\
researcher can choose for you) & \\
\hline Ethnicity: & \\
\hline Religion: & \\
\hline Subject specialism(s): & \\
\hline Number of years teaching: & \\
\hline
\end{tabular}

B) Demographic information: Student

\begin{tabular}{|l|l|}
\hline Name: & \\
\hline Pseudonym: (you may choose or the & \\
researcher can choose for you) & \\
\hline Age: & \\
\hline Ethnicity: & \\
\hline Religion: & \\
\hline
\end{tabular}




\section{Appendix H: Questions for focus group and semi-structured interviews}

\section{A) Questions for teacher interview}

1. To what extent is the importance of religion in the national curriculum?

2. Do you agree/disagree with the curriculum's stance towards religious pluralism and tolerance? Why?

3. In regards to the national curriculum, how would you define religious tolerance?

4. How important are the ideas of religious pluralism and tolerance to your identity as an Indonesian? How do these values effect your teaching?

5. A. For Religious Education Teachers: What importance does religious pluralism and tolerance have in teaching religious education?

B. For Citizenship Education Teachers: What importance does religious pluralism and tolerance have in teaching citizenship education?

6. What do you think of the religious tensions happening in some parts of Indonesia?

7. What identity would you affiliate with most closely?

\section{B) Questions for student focus group interview}

1. How important is the study of religion in your school?

2. How do you see your religious education teachers' stance towards religious pluralism and tolerance?

3. How do you see your citizenship education teachers' stance towards religious pluralism and tolerance?

4. How would you define religious tolerance?

5. As Indonesia is a multi-religious society, how would you define what it means to be an Indonesian?

6. What have you learned of religious tolerance and pluralism in your religious education class?

7. What have you learned of religious tolerance and pluralism in your citizenship education class?

8. What do you think of the religious tensions happening in some parts of Indonesia?

9. What identity would you affiliate most closely with? 